\title{
A Highly Catalytic Asymmetric Conjugate Addition: Synthesis of C14-C20 Fragment of Antibiotic TMC- 151A, Siphonarienal and Siphonarienone
}

\author{
Tze-Keong Lum and Teck-Peng Loh* \\ Division of Chemistry and Biological Chemistry, School of Physical and Mathematical Sciences, \\ Nanyang Technological University, Singapore 639798
}

Supporting Information

\section{Table of Contents}

General Methods.

Experimental Procedure and Characterization Data of Products.

${ }^{1} \mathrm{H}$ and ${ }^{13} \mathrm{C}$ NMR Spectra of Products. 


\section{General Methods}

Experiments involving moisture and/or air sensitive components were performed in oven-dried glassware under a positive pressure of nitrogen using freshly distilled solvents. Commercial grade solvents and reagents were used without further purification with the following exceptions: $t$-BuOMe was distilled from calcium hydride. Dichloromethane was distilled from calcium hydride. Diethyl Ether was distilled from sodium. Hexane, ethyl acetate were fractionally distilled.

Copper (I) iodide and $\mathrm{MeMgBr}$ (3 M in diethyl ether) were purchased from Aldrich; $\alpha, \beta$-unsaturated esters trans-2-pentenoate and trans-2-hexenoate were purchased from Acros and Alfa Aesar respectively; ( $R$ and $S$ )-TolBINAP were purchased from Strem and Alfa Aesar.

Analytical thin layer chromatography (TLC) was performed using Merck 60 F254 precoated silica gel plate (0.2 mm thickness). Subsequent to elution, plates were visualized using UV radiation (254 nm) on Spectroline Model ENF-24061/F $254 \mathrm{~nm}$. Further visualization was possible by staining with basic solution of potassium permanganate or acidic solution of ceric molybdate. Flash chromatography was performed using Merck silica gel 60 with freshly distilled solvents. Columns were typically packed as slurry and equilibrated with the appropriate solvent system prior to use.

Infrared spectra were recorded on a Bio-Rad FTS 165 FTIR spectrometer. The oil samples were examined under neat conditons. High Resolution Mass Spectrometry (HRMS) spectra were obtained using Finnigan MAT95XP GC/HRMS (Thermo Electron Corporation).

Proton nuclear magnetic resonance spectra ( ${ }^{1} \mathrm{H}$ NMR) were recorded on a Bruker Avance DPX 300 and Bruker AMX 400 spectrophotometer ( $\mathrm{CDCl}_{3}$ as solvent). Chemical shifts for ${ }^{1} \mathrm{H}$ NMR spectra are reported as $\delta$ in units of parts per million (ppm) downfield from TMS $(\delta 0.0)$ and relative to the signal of chloroform- $d(\delta 7.260$, singlet) as the internal standard. Multiplicities were given as: s (singlet); d (doublet); t (triplet); q (quartet); dd (doublets of doublet); ddd (doublets of doublets of doublet); dddd (doublets of doublets of doublets of doublet); dt (doublets of triplet); or $\mathrm{m}$ (multiplets). The number of protons (n) for a given resonance is indicated by $\mathrm{nH}$. Coupling constants are reported as a $J$ value in $\mathrm{Hz}$. Carbon nuclear magnetic resonance spectra $\left({ }^{13} \mathrm{C}\right.$ NMR) are reported as $\delta$ in units of parts per million (ppm) downfield from $\mathrm{SiMe}_{4}(\delta 0.0)$ and relative to the signal of chloroform- $d(\delta 77.03$, triplet). The proportion of diastereomers and geometric isomers was determined from the integration of ${ }^{1} \mathrm{H}$ NMR and ${ }^{13} \mathrm{C}$ NMR spectra.

Enantioselectivities were determined by capillary GC analysis (Chiraldex G-TA column (30 m x 0.25 mm)), using the flame ionization detector. Optical rotations were measured in $\mathrm{CHCl}_{3}$ on a Schmidt + Haensdch polarimeter (Polartronic MH8) with a $10.0 \mathrm{~mm}$ cell ( $c$ given in $\mathrm{g} / 100 \mathrm{~mL}$ ). Absolute configurations of the products were determined by comparison with known compounds. 


\section{Experimental Procedure and Characterization Data of Products}

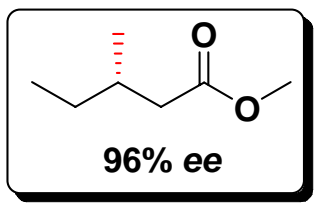

(S)-(+)-Methyl 3-methylpentanoate (1). In a round bottom flask equipped with septum and stirring bar, $(S)$-TolBINAP (1.03 g, $1.52 \mathrm{mmol})$ and $\mathrm{CuI}(0.19 \mathrm{~g}, 1.00 \mathrm{mmol})$ were stirred in $\mathrm{CH}_{2} \mathrm{Cl}_{2}(100 \mathrm{~mL})$ for 20 minutes, concentrated in vacuo and then stirred in $t$-BuOMe $(200 \mathrm{~mL})$ till a bright yellow suspension was observed. The mixture was then cooled to $-20{ }^{\circ} \mathrm{C}$ and $\mathrm{MeMgBr}\left(85 \mathrm{~mL}\right.$, Aldrich $3.0 \mathrm{M}$ solution in $\mathrm{Et}_{2} \mathrm{O}, 255$ mmol) was added carefully into the reaction mixture. After stirring for 15 minutes, a solution of methyl trans-2-pentenoate (5.71 g, $50 \mathrm{mmol})$ in $t$-BuOMe $(60 \mathrm{~mL})$ was added dropwise over $10 \mathrm{~h}$ via syringe pump. After stirring at $-20{ }^{\circ} \mathrm{C}$ for another $1 \mathrm{~h}$, the reaction mixture was quenched with $\mathrm{MeOH}(50 \mathrm{~mL})$ and saturated $\mathrm{NH}_{4} \mathrm{Cl}$ solution $(150 \mathrm{~mL})$. The aqueous layer was extracted with diethyl ether $(200 \mathrm{~mL}$ x 3) and the combined organic extracts were dried over anhydrous sodium sulfate, filtered and carefully concentrated in vacuo. The resulting residue was purified by flash chromatography (Pentane/Et $2 \mathrm{O} 99: 1$ ) to afford the desired product as colorless oil (4.37 g, 67\% yield): 96\% ee, was determined by employing a Chiraldex G-TA column (30 m x $0.25 \mathrm{~mm}$ ), $60{ }^{\circ} \mathrm{C}$, retention times (min): $\mathrm{t}_{1}=11.1$ (minor) , $\mathrm{t}_{2}=11.9$ (major); $[\alpha]_{\mathrm{D}}{ }^{20}=+5.9\left(c=1.0, \mathrm{CHCl}_{3}\right)$; FTIR (NaCl, neat): $1734 \mathrm{~cm}^{-1}$; ${ }^{1} \mathrm{H} \mathrm{NMR}(400 \mathrm{MHz}$, $\mathrm{CDCl}_{3}$ ): $\delta 3.65$ (s, 3H), 2.30 (dd, $\left.J=14.8,6.0 \mathrm{~Hz}, 1 \mathrm{H}\right), 2.09$ (dd, $\left.J=14.8,8.4 \mathrm{~Hz}, 1 \mathrm{H}\right), 1.87-1.85$ (m, 1H), 1.341.32 (m, 1H), 1.24-1.17 (m, 1H), 0.91 (d, $J=6.4 \mathrm{~Hz}, 3 \mathrm{H}), 0.87$ (t, $J=7.6 \mathrm{~Hz}, 3 \mathrm{H}) ;{ }^{13} \mathrm{C}$ NMR (100 MHz, CDCl $): \delta$ $173.9(\mathrm{C}), 51.3\left(\mathrm{CH}_{3}\right), 41.3,31.9(\mathrm{CH}), 29.3\left(\mathrm{CH}_{2}\right), 19.3\left(\mathrm{CH}_{2}\right), 11.3\left(\mathrm{CH}_{3}\right)$; HRMS (EI) calcd. for $\mathrm{C}_{7} \mathrm{H}_{14} \mathrm{O}_{2}$ 130.0994, $[\mathrm{M}]^{+}$found 130.0983. 


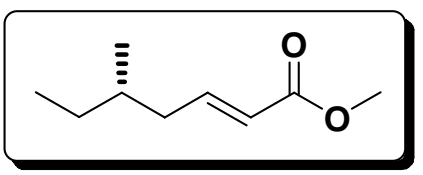

(S,E)-methyl 5-methylhept-2-enoate (2). In a round bottom flask equipped with a stirring bar, $(S)-(+)-M e t h y l ~ 3-$ methylpentanoate $(10.3 \mathrm{~g}, 79.1 \mathrm{mmol})$ was dissolved in hexane $(80 \mathrm{~mL})$ and cooled to $-78^{\circ} \mathrm{C}$. DIBAL-H (Aldrich 1 M solution in heptane, $90 \mathrm{~mL}, 90.0 \mathrm{mmol}$ ), pre-cooled to $-78^{\circ} \mathrm{C}$, was added carefully over several portions. After stirring for another $1.5 \mathrm{~h}, \mathrm{MeOH}(10 \mathrm{~mL})$, pre-cooled to $-78^{\circ} \mathrm{C}$ was added carefully over two portions and stirred for a further 0.5 hours till a white suspension was observed. Methyl (triphenylphosphoranylidene)acetate (54.0 g, 160 mmol) was added in one portion, followed by THF ( $400 \mathrm{~mL})$ and the reaction mixture was allowed to warm to room temperature over $1 \mathrm{~h}$ and stirred for another $1 \mathrm{~h}$. The mixture was then allowed reflux for an additional 6 hours. The mixture was then cooled to room temperature, carefully diluted with $\mathrm{Et}_{2} \mathrm{O}(100 \mathrm{~mL})$ and $6 \mathrm{~N} \mathrm{HCl}(200$ $\mathrm{mL}$ ), stirred vigorously at room temperature till a clear biphasic separation was observed. The aqueous layer was extracted with $\mathrm{Et}_{2} \mathrm{O}$ (200 mL x 2), and the combined organic extracts were washed with saturated $\mathrm{NaHCO}_{3}$ solution (200 mL x 1) dried over anhydrous sodium sulfate, filtered and concentrated in vacuo. The triphenylphosphine oxide was removed by filtering through a short silica plug using hexane. The filtrate was concentrated and purified by flash chromatography (40:1 Hexane/Ethyl Acetate) to afford the desired $E$-enoate as colorless oil (7.9 g, 64\% yield; 73\% yield for mixture of isomers $E / Z$, 92:8): Colorless oil, $48 \%$ yield, $[\alpha]_{\mathrm{D}}^{22}=+2.1\left(c=1.1, \mathrm{CH}_{2} \mathrm{Cl}_{2}\right)$; FTIR ( $\mathrm{NaCl}$, neat): $1746 \mathrm{~cm}^{-1}$; ${ }^{1} \mathrm{H}$ NMR (300 MHz, $\mathrm{CDCl}_{3}$ ): $\delta 6.95$ (dt, $J=15.6,7.6 \mathrm{~Hz}, 1 \mathrm{H}$ ), 5.81 (dt, $J=15.6,1.4 \mathrm{~Hz}$, 1H), 3.72 (s, 3H), 2.25-2.16 (m, 1H), 2.08-1.98 (m, 2H), 1.59-1.46 (m, 1H), 1.42-1.29 (m, 1H), 1.25-1.11 (m, 1H), 0.89 (d, $J=6.4 \mathrm{~Hz}, 3 \mathrm{H}), 0.88$ (t, $J=7.1 \mathrm{~Hz}, 3 \mathrm{H}) ;{ }^{13} \mathrm{C}$ NMR (100 MHz, $\mathrm{CDCl}_{3}$ ): $\delta 167.0$ (C), 148.7 (CH), 121.8 (CH), $51.3\left(\mathrm{CH}_{3}\right), 39.2\left(\mathrm{CH}_{2}\right), 34.1(\mathrm{CH}), 29.2\left(\mathrm{CH}_{2}\right), 19.1\left(\mathrm{CH}_{3}\right), 11.3\left(\mathrm{CH}_{3}\right)$; HRMS (EI) calcd. for $\mathrm{C}_{9} \mathrm{H}_{16} \mathrm{O}_{2}$ 156.1150, [M] $]^{+}$found 156.0077 . 


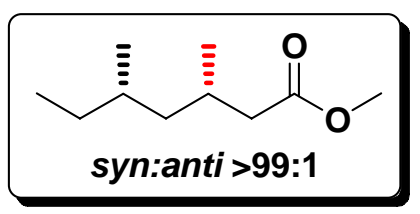

(3S,5S)-methyl 3, 5-dimethylheptanoate (3). In a round bottom flask equipped with septum and stirring bar, $(S)$ Tol-BINAP (1.03 g, $1.52 \mathrm{mmol})$ and $\mathrm{CuI}(0.19 \mathrm{~g}, 1.00 \mathrm{mmol})$ were stirred in $\mathrm{CH}_{2} \mathrm{Cl}_{2}(100 \mathrm{~mL})$ for 20 minutes, concentrated in vacuo and then stirred in $t$-BuOMe $(200 \mathrm{~mL})$ till a bright yellow suspension was observed. The mixture was then cooled to $-20{ }^{\circ} \mathrm{C}$ and $\mathrm{MeMgBr}$ (85 mL, Aldrich 3.0 M solution in $\mathrm{Et}_{2} \mathrm{O}, 255 \mathrm{mmol}$ ) was added carefully into the reaction mixture. After stirring for 15 minutes, a solution of $(S, E)$-methyl 5-methylhept-2-enoate (7.79 g, $50 \mathrm{mmol}$ ) in $t$-BuOMe $(60 \mathrm{~mL})$ was added dropwise over $10 \mathrm{~h}$ via syringe pump. After stirring at $-20{ }^{\circ} \mathrm{C}$ for another $1 \mathrm{~h}$, the reaction mixture was quenched with $\mathrm{MeOH}(50 \mathrm{~mL})$ and saturated $\mathrm{NH}_{4} \mathrm{Cl}$ solution $(150 \mathrm{~mL})$. The aqueous layer was extracted with diethyl ether $(200 \mathrm{~mL} \mathrm{x} \mathrm{3)}$ ) and the combined organic extracts were dried over anhydrous sodium sulfate, filtered and carefully concentrated in vacuo. The resulting residue was purified by flash chromatography (Hexane/Ethyl Acetate 30: 1) to afford the desired product as colorless oil (6.10 g, 65\% yield): $d r>99: 1$ in ${ }^{13} \mathrm{C}$ NMR using an average of two well resolved carbon signals and compared to a diastereomeric mixture (syn:anti 60:40) of methyl 3,5-dimethylheptanoate. Assuming an analogous reaction mechanism, syn-stereochemistry was assigned on the basis of enantiomeric Tol-BINAP ligands selected in each methyl addition leading to the deoxypropionate unit $\mathbf{3}$. In other words, two iterative applications of ( $S$ )-Tol-BINAP as the ligand in each methyl addition should lead to the syn-diastereomer; $[\alpha]_{\mathrm{D}}{ }^{22}=+4.1\left(c=1.2, \mathrm{CH}_{2} \mathrm{Cl}_{2}\right)$; FTIR (NaCl, neat): $1740 \mathrm{~cm}^{-1}$; ${ }^{1} \mathrm{H}$ NMR (400 MHz, $\mathrm{CDCl}_{3}$ ): $\delta 3.65$ (s, 3H), 2.33-2.26 (m, 1H), 2.07-1.98 (m, 2H), 1.411.30 (m, 2H), 1.26-1.19 (m, 1H), 1.15-1.05 (m, 1H), 1.03-0.94 (m, 1H), 0.91 (d, $J=6.0 \mathrm{~Hz}, 3 \mathrm{H}), 0.85$ (d, $J=5.0$ $\mathrm{Hz}, 3 \mathrm{H}), 0.84$ (t, $J=7.2 \mathrm{~Hz}, 3 \mathrm{H}) ;{ }^{13} \mathrm{C} \mathrm{NMR}(100 \mathrm{MHz}, \mathrm{CDCl})$ ): $\delta 173.8(\mathrm{C}), 51.3\left(\mathrm{CH}_{3}\right), 44.1\left(\mathrm{CH}_{2}\right), 41.6\left(\mathrm{CH}_{2}\right)$, 31.6 (CH), 29.0( $\left(\mathrm{CH}_{2}\right), 27.9(\mathrm{CH}), 20.4\left(\mathrm{CH}_{3}\right), 19.5\left(\mathrm{CH}_{3}\right), 11.1\left(\mathrm{CH}_{3}\right)$; HRMS (EI) calcd. for $\mathrm{C}_{10} \mathrm{H}_{20} \mathrm{O}_{2}$ 172.1463, $[\mathrm{M}]^{+}$found 172.1456 . 


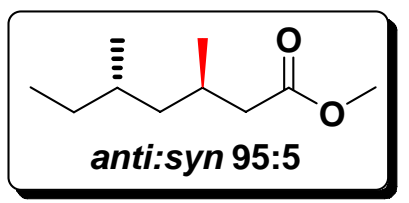

(3R,5S)-methyl 3, 5-dimethylheptanoate (4). In a round bottom flask equipped with septum and stirring bar, $(R)$ Tol-BINAP (0.103 g, $0.15 \mathrm{mmol})$ and $\mathrm{CuI}(0.019 \mathrm{~g}, 0.10 \mathrm{mmol})$ were stirred in $\mathrm{CH}_{2} \mathrm{Cl}_{2}(20 \mathrm{~mL})$ for 20 minutes, concentrated in vacuo and then stirred in $t$-BuOMe $(40 \mathrm{~mL})$ till a bright yellow suspension was observed. The mixture was then cooled to $-20{ }^{\circ} \mathrm{C}$ and $\mathrm{MeMgBr}\left(16.7 \mathrm{~mL}\right.$, Aldrich $3.0 \mathrm{M}$ solution in $\left.\mathrm{Et}_{2} \mathrm{O}, 50 \mathrm{mmol}\right)$ was added carefully into the reaction mixture. After stirring for 15 minutes, a solution of $(S, E)$-methyl 5-methylhept-2-enoate (0.78 g, $5.00 \mathrm{mmol})$ in $t$-BuOMe $(12 \mathrm{~mL})$ was added dropwise over $2 \mathrm{~h}$ via syringe pump. After stirring at $-20{ }^{\circ} \mathrm{C}$ for another $1 \mathrm{~h}$, the reaction mixture was quenched with $\mathrm{MeOH}(10 \mathrm{~mL})$ and saturated $\mathrm{NH}_{4} \mathrm{Cl}$ solution $(30 \mathrm{~mL})$. The aqueous layer was extracted with diethyl ether $(40 \mathrm{~mL} \mathrm{x} \mathrm{3)}$ ) and the combined organic extracts were dried over anhydrous sodium sulfate, filtered and carefully concentrated in vacuo. The resulting residue was purified by flash chromatography (Hexane/Ethyl Acetate 30: 1) to afford the desired product as colorless oil (0.54 g, 63\% yield): $d r$ 95:5 in ${ }^{13} \mathrm{C}$ NMR using an average of two well resolved carbon signals and compared to a diastereomeric mixture (syn:anti 60:40) of methyl 3,5-dimethylheptanoate. Assuming an analogous reaction mechanism, antistereochemistry was assigned on the basis of enantiomeric Tol-BINAP ligands selected in each methyl addition leading to the deoxypropionate unit 4 . In other words, the use of $(S)$-Tol-BINAP followed by $(R)$-Tol-BINAP as the ligands in the first and second methyl addition should lead to the anti-diastereomer; $[\alpha]_{\mathrm{D}}{ }^{22}=+16.9(c=1.5$, $\mathrm{CH}_{2} \mathrm{Cl}_{2}$ ); FTIR (NaCl, neat): $1742 \mathrm{~cm}^{-1}$; ${ }^{1} \mathrm{H}$ NMR (300 MHz, $\mathrm{CDCl}_{3}$ ): $\delta 3.66$ (s, 3H), 2.25 (dd, $J=15.4 \mathrm{and} 5.9 \mathrm{~Hz}$, 1H), 2.11 (dd, $J=14.5,7.9$ Hz, 1H), 2.11-1.88 (m, 1H), 1.45-1.34 (m, 1H), 1.33-1.23 (m, 2H), 1.21-1.11 (m, 1H), 1.10-1.00 (m, 1H), 0.91 (d, $J=6.5 \mathrm{~Hz}, 3 \mathrm{H}), 0.86$ (t, $J=7.6 \mathrm{~Hz}, 3 \mathrm{H}), 0.84$ (d, $J=6.4 \mathrm{~Hz}, 3 \mathrm{H}) ;{ }^{13} \mathrm{C}$ NMR $(75.4 \mathrm{MHz}$, $\left.\mathrm{CDCl}_{3}\right): \delta 173.7(\mathrm{C}), 51.3\left(\mathrm{CH}_{3}\right), 44.0\left(\mathrm{CH}_{2}\right), 42.4\left(\mathrm{CH}_{2}\right), 31.7(\mathrm{CH}), 30.1\left(\mathrm{CH}_{2}\right), 27.9(\mathrm{CH}), 19.4\left(\mathrm{CH}_{3}\right), 18.8\left(\mathrm{CH}_{3}\right)$, $11.4\left(\mathrm{CH}_{3}\right)$; HRMS (EI) calcd. for $\mathrm{C}_{10} \mathrm{H}_{20} \mathrm{O}_{2}$ 172.1463, [M] $]^{+}$found 172.1456. 


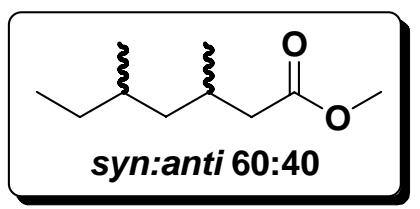

Methyl 3,5-dimethylheptanoate (4a). Diastereomeric mixtures were obtained using Gilman cuprates. Colorless oil: $d r$ 60:40 in ${ }^{13} \mathrm{C}$ NMR using an average of two well resolved carbon signals and the syn:anti configuration was assigned by analogy with the syn-diastereomer 3 and anti-diastereomer 4; FTIR ( $\mathrm{NaCl}$, neat): $1743 \mathrm{~cm}^{-1}$; ${ }^{1} \mathrm{H}$ NMR (400 MHz, $\mathrm{CDCl}_{3}$ ): $\delta 3.65$ (s, 3H), 2.34-2.19 (m, 1H), 2.14-.96 (m, 2H), 1.41-0.94 (m, 5H), 0.91-0.78 (m, 9H); ${ }^{13} \mathrm{C}$ NMR (100 MHz, CDCl $)_{3}$ : syn-diastereomer (60\%) $\delta 173.8(\mathrm{C}), 51.3\left(\mathrm{CH}_{3}\right), 44.1\left(\mathrm{CH}_{2}\right), 41.5\left(\mathrm{CH}_{2}\right), 31.5(\mathrm{CH})$, 29.0 $\left(\mathrm{CH}_{2}\right)$, $27.9(\mathrm{CH}), 20.4\left(\mathrm{CH}_{3}\right), 19.5\left(\mathrm{CH}_{3}\right), 11.0\left(\mathrm{CH}_{3}\right)$; anti-diastereomer $(40 \%) \delta 173.7(\mathrm{C}), 51.3\left(\mathrm{CH}_{3}\right), 43.9$ $\left(\mathrm{CH}_{2}\right)$, $42.4\left(\mathrm{CH}_{2}\right), 31.6(\mathrm{CH}), 30.1\left(\mathrm{CH}_{2}\right), 27.8(\mathrm{CH}), 19.4\left(\mathrm{CH}_{3}\right), 18.8\left(\mathrm{CH}_{3}\right)$, $11.4\left(\mathrm{CH}_{3}\right)$; HRMS (EI) calcd. for $\mathrm{C}_{10} \mathrm{H}_{20} \mathrm{O}_{2}$ 172.1463, [M] $]^{+}$found 172.1456. 


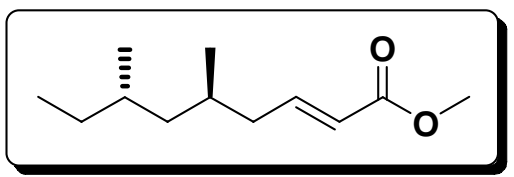

$(5 R, 7 S, E)$-methyl 5,7-dimethylnon-2-enoate (5). In a round bottom flask equipped with a stirring bar, $(3 R, 5 S)$ methyl 3, 5-dimethylheptanoate $(0.40 \mathrm{~g}, 2.3 \mathrm{mmol})$ was dissolved in hexane $(3.0 \mathrm{~mL})$ and cooled to $-78^{\circ} \mathrm{C}$. DIBAL$\mathrm{H}$ (Aldrich $1 \mathrm{M}$ solution in heptane, $3.0 \mathrm{~mL}, 3.0 \mathrm{mmol}$ ), pre-cooled to $-78^{\circ} \mathrm{C}$, was added carefully over several portions. After stirring for another $1.5 \mathrm{~h}, \mathrm{MeOH}(0.5 \mathrm{~mL})$, pre-cooled to $-78^{\circ} \mathrm{C}$ was added carefully over two portions and stirred for a further 0.5 hours till a white suspension was observed. Methyl (triphenylphosphoranylidene)acetate $(1.40 \mathrm{~g}, 4.2 \mathrm{mmol})$ was added in one portion, followed by THF $(9 \mathrm{~mL})$ and the reaction mixture was allowed to warm to room temperature over $1 \mathrm{~h}$ and stirred for another $1 \mathrm{~h}$. The mixture was then allowed reflux for an additional 6 hours. The mixture was then cooled to room temperature, carefully diluted with $\mathrm{Et}_{2} \mathrm{O}(5 \mathrm{~mL})$ and $6 \mathrm{~N} \mathrm{HCl}(10 \mathrm{~mL})$, stirred vigorously at room temperature till a clear biphasic separation was observed. The aqueous layer was extracted with $\mathrm{Et}_{2} \mathrm{O}(5 \mathrm{~mL}$ x 2), and the combined organic extracts were washed with saturated $\mathrm{NaHCO}_{3}$ solution $(10 \mathrm{~mL}$ x 1) dried over anhydrous sodium sulfate, filtered and concentrated in vacuo. The triphenylphosphine oxide was removed by filtering through a short silica plug using hexane. The filtrate was concentrated and purified by flash chromatography (50:1 Hexane/Ethyl Acetate) to afford the desired $E$-enoate (0.269 g, $59 \%$ yield; 71\% yield for mixture of isomers $E / Z, 90: 10)$ as colorless oil: $[\alpha]_{\mathrm{D}}{ }^{22}=+12.1(c=1.0$, $\mathrm{CH}_{2} \mathrm{Cl}_{2}$ ); FTIR (NaCl, neat): $1672 \mathrm{~cm}^{-1}$; ${ }^{1} \mathrm{H}$ NMR (400 MHz, $\left.\mathrm{CDCl}_{3}\right): \delta 6.94$ (dt, $\left.J=15.6,7.8 \mathrm{~Hz}, 1 \mathrm{H}\right), 5.80$ (d, $J=$ 15.6, 1H), 3.72 (s, 3H), 2.19-2.12 (m, 1H), 2.07-1.99 (m, 1H), 1.74-1.65 (m, 1H), 1.44-1.35 (m, 1H), 1.34-1.23 (m, 2H), 1.18-1.03 (m, 3H), 0.88-0.83 (m, 6H), 0.81 (d, $J=6.5 \mathrm{~Hz}, 3 \mathrm{H}) ;{ }^{13} \mathrm{C}$ NMR (100 MHz, $\left.\mathrm{CDCl}_{3}\right): \delta 167.1$ (C), 148.6 (CH), $121.9(\mathrm{CH}), 51.3\left(\mathrm{CH}_{3}\right), 43.9\left(\mathrm{CH}_{2}\right) 40.5\left(\mathrm{CH}_{2}\right), 31.7(\mathrm{CH}), 30.2(\mathrm{CH}), 29.9\left(\mathrm{CH}_{2}\right), 19.3\left(\mathrm{CH}_{3}\right), 18.8$ $\left(\mathrm{CH}_{3}\right)$, $11.4\left(\mathrm{CH}_{3}\right)$; LRMS (EI) calcd. for $\mathrm{C}_{12} \mathrm{H}_{22} \mathrm{O}_{2}$ 198.16, [M+H] $]^{+}$found 199.13. 


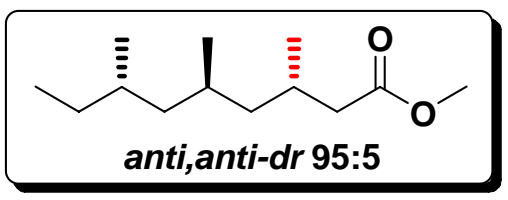

(3S,5R,7S)-methyl 3,5,7-trimethylnonanoate (6). In a round bottom flask equipped with septum and stirring bar, (S)-Tol-BINAP (0.0054 g, $0.008 \mathrm{mmol})$ and $\mathrm{CuI}(0.0010 \mathrm{~g}, 0.005 \mathrm{mmol})$ were stirred in $\mathrm{CH}_{2} \mathrm{Cl}_{2}(1 \mathrm{~mL})$ for 10 minutes, concentrated in vacuo and then stirred in $t$-BuOMe $(1.0 \mathrm{~mL})$ till a bright yellow suspension was observed. The mixture was then cooled to $-20{ }^{\circ} \mathrm{C}$ and $\mathrm{MeMgBr}\left(0.42 \mathrm{~mL}\right.$, Aldrich $3.0 \mathrm{M}$ solution in $\left.\mathrm{Et}_{2} \mathrm{O}, 1.25 \mathrm{mmol}\right)$ was added carefully into the reaction mixture. After stirring for 15 minutes, a solution of (5R,7S,E)-methyl 5,7dimethylnon-2-enoate $(0.049 \mathrm{~g}, 0.25 \mathrm{mmol})$ in $t$-BuOMe $(0.30 \mathrm{~mL})$ was added dropwise over $1 \mathrm{~h}$ via syringe pump. After stirring at $-20{ }^{\circ} \mathrm{C}$ for another $1 \mathrm{~h}$, the reaction mixture was quenched with $\mathrm{MeOH}(1 \mathrm{~mL})$ and saturated $\mathrm{NH}_{4} \mathrm{Cl}$ solution (3 mL). The aqueous layer was extracted with diethyl ether ( $2 \mathrm{~mL} x 3)$ and the combined organic extracts were dried over anhydrous sodium sulfate, filtered and carefully concentrated in vacuo. The resulting residue was purified by flash chromatography (Hexane/Ethyl Acetate 30: 1) to afford the desired product as colorless oil (0.035 g, 66\% yield): $d r$ 95:5 in ${ }^{13} \mathrm{C}$ NMR using an average of three well resolved carbon signals and compared to a diastereomeric mixture of methyl 3,5,7-trimethylnonanoate. Assuming an analogous reaction mechanism, anti,antistereochemistry was assigned on the basis of enantiomeric Tol-BINAP ligands selected in each methyl addition leading to the deoxypropionate unit $\mathbf{6}$. In other words, the respective use of $(S)$-Tol-BINAP, $(R)$-Tol-BINAP and $(S)$-Tol-BINAP as the ligands in the respective three methyl additions should lead to the anti,anti-diastereomer; $[\alpha]_{\mathrm{D}}{ }^{22}=+23.1\left(c=1.1, \mathrm{CHCl}_{3}\right)$; FTIR ( $\mathrm{NaCl}$, neat): $1672 \mathrm{~cm}^{-1} ;{ }^{1} \mathrm{H}$ NMR (400 MHz, $\left.\mathrm{CDCl}_{3}\right): \delta 3.67$ (s, 3H), 2.26 (dd, $J=14.1,5.7 \mathrm{~Hz}, 1 \mathrm{H}), 2.15-2.01$ (m, 2H), 1.58-1.51 (m, 1H), 1.44-1.33 (m, 1H), 1.33-1.22 (m, 2H), 1.19-1.05 (m, 3H), 1.04-0.95 (m, 1H), 0.91 (d, $J=6.5 \mathrm{~Hz}, 3 \mathrm{H}), 0.87-0.81(\mathrm{~m}, 9 \mathrm{H}) ;{ }^{13} \mathrm{C}$ NMR $\left(100 \mathrm{MHz}, \mathrm{CDCl}_{3}\right)$ : anti,antidiastereomer (95\%) $\delta 173.7(\mathrm{C}), 51.3\left(\mathrm{CH}_{3}\right), 45.2\left(\mathrm{CH}_{2}\right), 45.0\left(\mathrm{CH}_{2}\right) 42.4\left(\mathrm{CH}_{2}\right), 31.6(\mathrm{CH}), 30.2\left(\mathrm{CH}_{2}\right), 27.8(\mathrm{CH})$, $27.3(\mathrm{CH}), 19.5\left(\mathrm{CH}_{3}\right), 19.1\left(\mathrm{CH}_{3}\right), 19.0\left(\mathrm{CH}_{3}\right), 11.4\left(\mathrm{CH}_{3}\right)$; minor anti,syn-diastereomer (3\%); minor syn,syndiastereomer 9 (2\%); HRMS (EI) calcd. for $\mathrm{C}_{13} \mathrm{H}_{26} \mathrm{O}_{2}$ 214.1933, [M-H] $]^{+}$found 213.1849. 


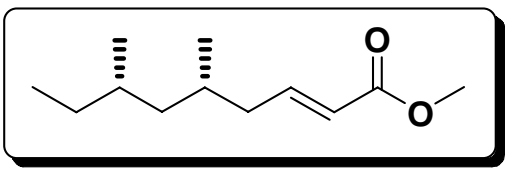

(5S,7S,E)-methyl 5,7-dimethylnon-2-enoate (7). In a round bottom flask equipped with a stirring bar, (3R,5S)methyl 3,5-dimethylheptanoate $(0.80 \mathrm{~g}, 4.6 \mathrm{mmol})$ was dissolved in hexane $(6.0 \mathrm{~mL})$ and cooled to $-78^{\circ} \mathrm{C}$. DIBAL$\mathrm{H}$ (Aldrich $1 \mathrm{M}$ solution in heptane, $6.0 \mathrm{~mL}, 6.0 \mathrm{mmol}$ ), pre-cooled to $-78^{\circ} \mathrm{C}$, was added carefully over several portions. After stirring for another $1.5 \mathrm{~h}, \mathrm{MeOH}(1.0 \mathrm{~mL})$, pre-cooled to $-78^{\circ} \mathrm{C}$ was added carefully over two portions and stirred for a further 0.5 hours till a white suspension was observed. Methyl (triphenylphosphoranylidene)acetate (2.80 g, $8.4 \mathrm{mmol}$ ) was added in one portion, followed by THF (18 mL) and the reaction mixture was allowed to warm to room temperature over $1 \mathrm{~h}$ and stirred for another $1 \mathrm{~h}$. The mixture was then allowed reflux for an additional 6 hours. The mixture was then cooled to room temperature, carefully diluted with $\mathrm{Et}_{2} \mathrm{O}(10 \mathrm{~mL})$ and $6 \mathrm{~N} \mathrm{HCl}(20 \mathrm{~mL})$, stirred vigorously at room temperature till a clear biphasic separation was observed. The aqueous layer was extracted with $\mathrm{Et}_{2} \mathrm{O}(10 \mathrm{~mL} \times 2)$, and the combined organic extracts were washed with saturated $\mathrm{NaHCO}_{3}$ solution $(20 \mathrm{~mL}$ x 1) dried over anhydrous sodium sulfate, filtered and concentrated in vacuo. The triphenylphosphine oxide was removed by filtering through a short silica plug using hexane. The filtrate was concentrated and purified by flash chromatography (50:1 Hexane/Ethyl Acetate) to afford the desired $E$-enoate $(0.56 \mathrm{~g}, 61 \%$ yield; $72 \%$ yield for mixture of isomers $E / Z, 91: 9)$ as colorless oil: $[\alpha]_{\mathrm{D}}{ }^{22}=+3.1$ $\left(c=1.5, \mathrm{CH}_{2} \mathrm{Cl}_{2}\right.$ ); FTIR ( $\mathrm{NaCl}$, neat): $1673 \mathrm{~cm}^{-1} ;{ }^{1} \mathrm{H}$ NMR (300 MHz, $\left.\mathrm{CDCl}_{3}\right): \delta 6.95(\mathrm{dt}, J=15.3,7.7 \mathrm{~Hz}, 1 \mathrm{H})$, 5.81 (dt, $J=15.3,1.4 \mathrm{~Hz}, 1 \mathrm{H}), 3.73$ (s, 3H), 2.26-2.17 (m, 1H), 2.03-1.93 (m, 1H), 1.77-1.63 (m, 1H), 1.47-1.34 (m, 1H), 1.32-1.19 (m, 2H), 1.12-1.03 (m, 1H), 1.02-0.93 (m, 1H), 0.88 (d, $J=6.6 \mathrm{~Hz}, 3 \mathrm{H}), 0.85$ (t, $J=7.2 \mathrm{~Hz}, 3 \mathrm{H})$, 0.84 (d, $J=6.5 \mathrm{~Hz}, 3 \mathrm{H}) ;{ }^{13} \mathrm{C}$ NMR (75.4 MHz, $\left.\mathrm{CDCl}_{3}\right): \delta 167.0(\mathrm{C}), 148.5(\mathrm{CH}), 121.9(\mathrm{CH}), 51.3\left(\mathrm{CH}_{3}\right), 44.0$ $\left(\mathrm{CH}_{2}\right) 39.4\left(\mathrm{CH}_{2}\right), 31.5(\mathrm{CH}), 29.8(\mathrm{CH}), 29.1\left(\mathrm{CH}_{2}\right), 20.1\left(\mathrm{CH}_{3}\right), 19.5\left(\mathrm{CH}_{3}\right), 11.1\left(\mathrm{CH}_{3}\right)$; LRMS (EI) calcd. for $\mathrm{C}_{12} \mathrm{H}_{22} \mathrm{O}_{2}$ 198.16, $[\mathrm{M}+\mathrm{H}]^{+}$found 199.13. 


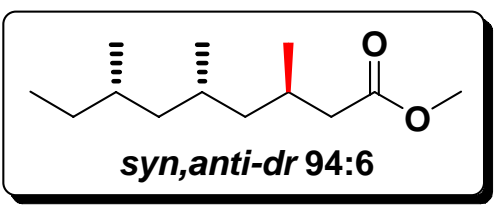

(3R,5S,7S)-methyl 3,5,7-trimethylnonanoate (8). In a round bottom flask equipped with septum and stirring bar, $(R)$-Tol-BINAP $(0.0054 \mathrm{~g}, 0.008 \mathrm{mmol})$ and $\mathrm{CuI}(0.0010 \mathrm{~g}, 0.005 \mathrm{mmol})$ were stirred in $\mathrm{CH}_{2} \mathrm{Cl}_{2}(1 \mathrm{~mL})$ for 10 minutes, concentrated in vacuo and then stirred in $t$-BuOMe $(1.0 \mathrm{~mL})$ till a bright yellow suspension was observed. The mixture was then cooled to $-20{ }^{\circ} \mathrm{C}$ and $\mathrm{MeMgBr}\left(0.42 \mathrm{~mL}\right.$, Aldrich $3.0 \mathrm{M}$ solution in $\left.\mathrm{Et}_{2} \mathrm{O}, 1.25 \mathrm{mmol}\right)$ was added carefully into the reaction mixture. After stirring for 15 minutes, a solution of (5R,7S,E)-methyl 5,7dimethylnon-2-enoate $(0.049 \mathrm{~g}, 0.25 \mathrm{mmol})$ in $t$-BuOMe $(0.30 \mathrm{~mL})$ was added dropwise over $1 \mathrm{~h}$ via syringe pump. After stirring at $-20{ }^{\circ} \mathrm{C}$ for another $1 \mathrm{~h}$, the reaction mixture was quenched with $\mathrm{MeOH}(1 \mathrm{~mL})$ and saturated $\mathrm{NH}_{4} \mathrm{Cl}$ solution (3 mL). The aqueous layer was extracted with diethyl ether $(2 \mathrm{~mL} x 3)$ and the combined organic extracts were dried over anhydrous sodium sulfate, filtered and carefully concentrated in vacuo. The resulting residue was purified by flash chromatography (Hexane/Ethyl Acetate 30: 1) to afford the desired product as colorless oil (0.032 g, 62\% yield): $d r$ 94:6 in ${ }^{13} \mathrm{C}$ NMR using an average of three well resolved carbon signals and compared to a diastereomeric mixture of methyl 3,5,7-trimethylnonanoate. Assuming an analogous reaction mechanism, syn,antistereochemistry was assigned on the basis of enantiomeric Tol-BINAP ligands selected in each methyl addition leading to the deoxypropionate unit $\mathbf{8}$. In other words, the respective use of ( $S$ )-Tol-BINAP, $(S)$-Tol-BINAP and $(R)$-Tol-BINAP as the ligands in the respective three methyl additions should lead to the syn,anti-diastereomer; $[\alpha]_{\mathrm{D}}^{22}=+6.1\left(c=1.1, \mathrm{CHCl}_{3}\right)$; FTIR ( $\mathrm{NaCl}$, neat): $1737 \mathrm{~cm}^{-1} ;{ }^{1} \mathrm{H}$ NMR (400 MHz, $\left.\mathrm{CDCl}_{3}\right): \delta 3.66$ (s, 3H), 2.24 (dd, $J=14.6,6.3 \mathrm{~Hz}, 1 \mathrm{H}), 2.16-2.04$ (m, 2H), 1.58-1.49 (m, 1H), 1.45-1.22 (m, 3H), 1.20-0.92 (m, 4H), 0.90 (d, $J=6.4$ $\mathrm{Hz}, 3 \mathrm{H}), 0.86-0.80$ (m, 9H); ${ }^{13} \mathrm{C}$ NMR (100 MHz, $\mathrm{CDCl}_{3}$ ): major syn,anti-diastereomer (94\%) $\delta 173.7$ (C), 51.3 $\left(\mathrm{CH}_{3}\right), 45.4\left(\mathrm{CH}_{2}\right), 44.1\left(\mathrm{CH}_{2}\right)$ 42.6.3 $\left(\mathrm{CH}_{2}\right), 31.4(\mathrm{CH}), 29.3\left(\mathrm{CH}_{2}\right), 27.8(\mathrm{CH}), 27.3(\mathrm{CH}), 19.9\left(\mathrm{CH}_{3}\right), 19.5\left(\mathrm{CH}_{3}\right)$, $19.3\left(\mathrm{CH}_{3}\right), 11.2\left(\mathrm{CH}_{3}\right)$; minor syn,syn-diastereomer (3\%); minor anti,syn-diastereomer (3\%); HRMS (EI) calcd. for HRMS (EI) calcd. for $\mathrm{C}_{13} \mathrm{H}_{26} \mathrm{O}_{2}$ 214.1933, [M-H] $]^{+}$found 213.1949 . 


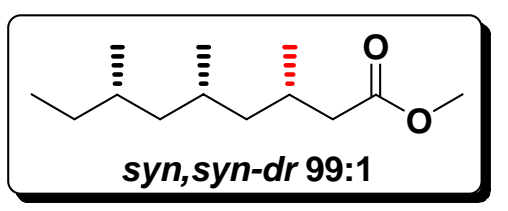

(3S,5S,7S)-methyl 3,5,7-trimethylnonanoate (9). In a round bottom flask equipped with septum and stirring bar, $(R)$-Tol-BINAP $(0.0054 \mathrm{~g}, 0.008 \mathrm{mmol})$ and $\mathrm{CuI}(0.0010 \mathrm{~g}, 0.005 \mathrm{mmol})$ were stirred in $\mathrm{CH}_{2} \mathrm{Cl}_{2}(1 \mathrm{~mL})$ for 10 minutes, concentrated in vacuo and then stirred in $t$-BuOMe $(1.0 \mathrm{~mL})$ till a bright yellow suspension was observed. The mixture was then cooled to $-20{ }^{\circ} \mathrm{C}$ and $\mathrm{MeMgBr}\left(0.42 \mathrm{~mL}\right.$, Aldrich $3.0 \mathrm{M}$ solution in $\left.\mathrm{Et}_{2} \mathrm{O}, 1.25 \mathrm{mmol}\right)$ was added carefully into the reaction mixture. After stirring for 15 minutes, a solution of (5R,7S,E)-methyl 5,7dimethylnon-2-enoate $(0.049 \mathrm{~g}, 0.25 \mathrm{mmol})$ in $t$-BuOMe $(0.30 \mathrm{~mL})$ was added dropwise over $1 \mathrm{~h}$ via syringe pump. After stirring at $-20{ }^{\circ} \mathrm{C}$ for another $1 \mathrm{~h}$, the reaction mixture was quenched with $\mathrm{MeOH}(1 \mathrm{~mL})$ and saturated $\mathrm{NH}_{4} \mathrm{Cl}$ solution (3 mL). The aqueous layer was extracted with diethyl ether $(2 \mathrm{~mL} x 3)$ and the combined organic extracts were dried over anhydrous sodium sulfate, filtered and carefully concentrated in vacuo. The resulting residue was purified by flash chromatography (Hexane/Ethyl Acetate 30: 1) to afford the desired product as colorless oil (0.029 g, 58\% yield): $d r$ 99:1 in ${ }^{13} \mathrm{C}$ NMR using an average of three well resolved carbon signals and compared to a diastereomeric mixture of methyl 3,5,7-trimethylnonanoate. Assuming an analogous reaction mechanism, syn,synstereochemistry was assigned on the basis of enantiomeric Tol-BINAP ligands selected in each methyl addition leading to the deoxypropionate unit $\mathbf{9}$. In other words, the respective use of ( $S$ )-Tol-BINAP, $(S)$-Tol-BINAP and $(S)$-Tol-BINAP as the ligands in the respective three methyl additions should lead to the syn,syn-diastereomer; $[\alpha]_{\mathrm{D}}^{22}=+2.5\left(c=1.3, \mathrm{CH}_{2} \mathrm{Cl}_{2}\right)$; Note: contains trace amount of phosphine oxide as impurity. FTIR ( $\mathrm{NaCl}$, neat): $1738 \mathrm{~cm}^{-1}$; ${ }^{1} \mathrm{H}$ NMR (300 MHz, $\mathrm{CDCl}_{3}$ ): $\delta 3.65$ (s, 3H), 2.37-2.23 (m, 1H), 2.11-1.99 (m, 2H), 1.70-1.59 (m, 1H), 1.56-1.48 (m, 1H), 1.45-1.29 (m, 1H), 1.27-1.17 (m, 2H), 1.10-0.98 (m, 3H), 0.93 (d, $J=6.1 \mathrm{~Hz}, 3 \mathrm{H}), 0.85$ (t, $J=$ $7.7 \mathrm{~Hz}, 3 \mathrm{H}), 0.84$ (t, $J=7.2 \mathrm{~Hz}, 6 \mathrm{H}) ;{ }^{13} \mathrm{C}$ NMR (100 MHz, $\left.\mathrm{CDCl}_{3}\right)$ : major syn,syn-diastereomer (99\%) $\delta 173.8$ (C), $51.3\left(\mathrm{CH}_{3}\right), 44.8\left(\mathrm{CH}_{2}\right), 44.6\left(\mathrm{CH}_{2}\right) 41.3\left(\mathrm{CH}_{2}\right), 31.4(\mathrm{CH}), 28.9\left(\mathrm{CH}_{2}\right), 27.8(\mathrm{CH}), 27.4(\mathrm{CH}), 20.6\left(\mathrm{CH}_{3}\right), 20.6$ $\left(\mathrm{CH}_{3}\right), 19.8\left(\mathrm{CH}_{3}\right), 11.1\left(\mathrm{CH}_{3}\right)$; HRMS (EI) calcd. for $\mathrm{C}_{13} \mathrm{H}_{26} \mathrm{O}_{2}$ 214.1933, [M-H] ${ }^{+}$found 213.1949. 


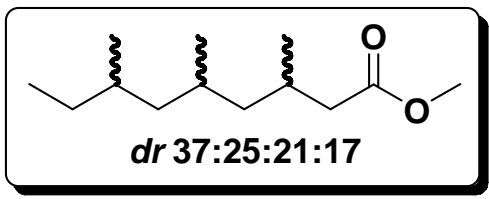

Methyl 3,5,7-trimethylnonanoate (9a). Diastereomeric mixtures were obtained using Gilman cuprates. Colorless oil: $d r$ 37:25:21:17 in ${ }^{13} \mathrm{C}$ NMR using an average of three well resolved carbon signals and the relative stereochemistry was assigned by analogy with the anti,anti-diastereomer $\mathbf{6}$, syn,anti-diastereomer $\mathbf{8}$ and the syn,syn-diastereomer $\mathbf{9}$; FTIR (NaCl, neat): $1736 \mathrm{~cm}^{-1}$; ${ }^{1} \mathrm{H}$ NMR (400 MHz, $\mathrm{CDCl}_{3}$ ): $\delta 3.63$ (s, 3H), 2.33-2.19 (m, 1H), 2.14-1.99 (m, 2H), 1.57-1.48 (m, 1H), 1.42-1.30 (m, 2H), 1.29-1.10 (m, 2H), 1.08-0.94 (m, 3H), 0.90-0.87 (m, 3H), 0.85-0.78 (m, 9H); ${ }^{13} \mathrm{C}$ NMR (100 MHz, $\left.\mathrm{CDCl}_{3}\right)$ : syn, syn-diastereomer 9 (37\%) $\delta 173.7(\mathrm{C}), 51.2\left(\mathrm{CH}_{3}\right), 44.7\left(\mathrm{CH}_{2}\right), 44.6\left(\mathrm{CH}_{2}\right) 41.2$ $\left(\mathrm{CH}_{2}\right)$, $31.4(\mathrm{CH}), 28.8\left(\mathrm{CH}_{2}\right), 27.8(\mathrm{CH}), 27.2(\mathrm{CH}), 20.5\left(\mathrm{CH}_{3}\right), 20.5\left(\mathrm{CH}_{3}\right), 19.8\left(\mathrm{CH}_{3}\right), 11.1\left(\mathrm{CH}_{3}\right)$; anti,syn-diastereomer (25 \%) $\delta 173.6(\mathrm{C}), 51.2\left(\mathrm{CH}_{3}\right), 45.4\left(\mathrm{CH}_{2}\right), 43.9\left(\mathrm{CH}_{2}\right) 41.6\left(\mathrm{CH}_{2}\right), 31.4(\mathrm{CH}), 30.5\left(\mathrm{CH}_{2}\right)$, $27.7(\mathrm{CH}), 27.4(\mathrm{CH}), 20.1\left(\mathrm{CH}_{3}\right), 19.9\left(\mathrm{CH}_{3}\right), 19.9\left(\mathrm{CH}_{3}\right), 11.2\left(\mathrm{CH}_{3}\right)$; syn,anti-diastereomer $8(21 \%) \delta 173.7(\mathrm{C})$, $51.2\left(\mathrm{CH}_{3}\right), 45.3\left(\mathrm{CH}_{2}\right), 44.0\left(\mathrm{CH}_{2}\right) 42.5\left(\mathrm{CH}_{2}\right), 31.6(\mathrm{CH}), 29.3\left(\mathrm{CH}_{2}\right), 27.7(\mathrm{CH}), 27.3(\mathrm{CH}), 19.4\left(\mathrm{CH}_{3}\right), 19.2$ $\left(\mathrm{CH}_{3}\right), 18.8\left(\mathrm{CH}_{3}\right), 11.4\left(\mathrm{CH}_{3}\right)$; anti,anti-diastereomer $6(17 \%) \delta 173.6(\mathrm{C}), 51.2\left(\mathrm{CH}_{3}\right), 45.1\left(\mathrm{CH}_{2}\right), 45.0\left(\mathrm{CH}_{2}\right)$ $42.3\left(\mathrm{CH}_{2}\right), 31.5(\mathrm{CH}), 30.2\left(\mathrm{CH}_{2}\right), 27.7(\mathrm{CH}), 27.3(\mathrm{CH}), 19.4\left(\mathrm{CH}_{3}\right), 19.0\left(\mathrm{CH}_{3}\right), 19.0\left(\mathrm{CH}_{3}\right), 11.3\left(\mathrm{CH}_{3}\right)$; HRMS (EI) calcd. for $\mathrm{C}_{13} \mathrm{H}_{26} \mathrm{O}_{2} 214.1933[\mathrm{M}-\mathrm{H}]^{+}$found 213.1947. 


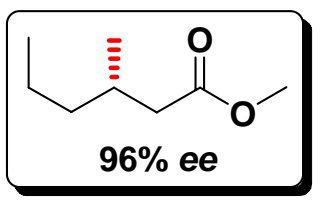

(S)-Methyl 3-methylhexanoate (12). In a round bottom flask equipped with septum and stirring bar, $(S)$-TolBINAP (1.03 g, $1.52 \mathrm{mmol})$ and $\mathrm{CuI}(0.19 \mathrm{~g}, 1.00 \mathrm{mmol})$ were stirred in $\mathrm{CH}_{2} \mathrm{Cl}_{2}(100 \mathrm{~mL})$ for 20 minutes, concentrated in vacuo and then stirred in $t$-BuOMe $(200 \mathrm{~mL})$ till a bright yellow suspension was observed. The mixture was then cooled to $-20{ }^{\circ} \mathrm{C}$ and $\mathrm{MeMgBr}\left(85 \mathrm{~mL}\right.$, Aldrich 3.0 M solution in $\mathrm{Et}_{2} \mathrm{O}, 255 \mathrm{mmol}$ ) was added carefully into the reaction mixture. After stirring for 15 minutes, a solution of methyl trans-2-hexenoate (6.41 g, 50 mmol) in $t$-BuOMe (60 mL) was added dropwise over $10 \mathrm{~h}$ via syringe pump. After stirring at $-20{ }^{\circ} \mathrm{C}$ for another 1 h, the reaction mixture was quenched with $\mathrm{MeOH}(50 \mathrm{~mL})$ and saturated $\mathrm{NH}_{4} \mathrm{Cl}$ solution $(150 \mathrm{~mL})$. The aqueous layer was extracted with diethyl ether (200 mL x 3) and the combined organic extracts were dried over anhydrous sodium sulfate, filtered and carefully concentrated in vacuo. The resulting residue was purified by flash chromatography (Pentane/Et ${ }_{2} \mathrm{O}$ 99: 1) to afford the desired product as colorless oil (4.90 g, 68\% yield): 96\% ee, was determined by employing a Chiraldex G-TA column (30 m x $0.25 \mathrm{~mm}$ ), $60{ }^{\circ} \mathrm{C}$, retention times (min): $\mathrm{t}_{1}=18.2$ (minor) , $\mathrm{t}_{2}=19.2$ (major); $[\alpha]_{\mathrm{D}}{ }^{25}=+2.3\left(c=0.9, \mathrm{CHCl}_{3}\right)$; FTIR ( $\mathrm{NaCl}$, neat): $1737 \mathrm{~cm}^{-1} ;{ }^{1} \mathrm{H} \mathrm{NMR}(400 \mathrm{MHz}$, $\mathrm{CDCl}_{3}$ ): $\delta 3.66$ (s, 3H), 2.30 (dd, $\left.J=14.6,6.0 \mathrm{~Hz}, 1 \mathrm{H}\right), 2.10$ (dd, $\left.J=14.6,8.0 \mathrm{~Hz}, 1 \mathrm{H}\right), 1.95-1.96(\mathrm{~m}, 1 \mathrm{H}), 1.35-$ $1.21(\mathrm{~m}, 4 \mathrm{H}), 0.92$ (d, $J=6.80 \mathrm{~Hz}, 3 \mathrm{H}), 0.89$ (t, $J=7.2 \mathrm{~Hz}, 3 \mathrm{H}) ;{ }^{13} \mathrm{C}$ NMR (100 MHz, $\mathrm{CDCl}_{3}$ ): $\delta 173.9$ (C), 51.4 $\left(\mathrm{CH}_{3}\right), 41.7\left(\mathrm{CH}_{2}\right), 39.0\left(\mathrm{CH}_{2}\right), 30.1(\mathrm{CH}), 20.0\left(\mathrm{CH}_{2}\right), 19.7\left(\mathrm{CH}_{3}\right), 14.2\left(\mathrm{CH}_{3}\right)$; HRMS (EI) calcd. for $\mathrm{C}_{8} \mathrm{H}_{16} \mathrm{O}_{2}$ 144.1150, [M] $]^{+}$found 144.1143. 


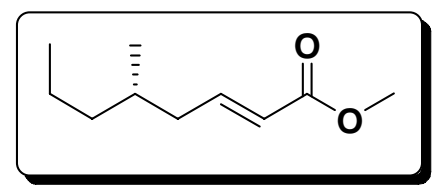

(S,E)-Methyl 5-methyloct-2-enoate (13). In a round bottom flask equipped with a stirring bar, $(S)$-methyl 3methylhexanoate 1 (11.6 g, $80.4 \mathrm{mmol}$ ) was dissolved in hexane $\left(80 \mathrm{~mL}\right.$ ) and cooled to $-78^{\circ} \mathrm{C}$. DIBAL-H (Aldrich $1 \mathrm{M}$ solution in heptane, $90 \mathrm{~mL}, 90.0 \mathrm{mmol}$ ), pre-cooled to $-78^{\circ} \mathrm{C}$, was added carefully over several portions. After stirring for another $1.5 \mathrm{~h}, \mathrm{MeOH}(10 \mathrm{~mL})$, pre-cooled to $-78^{\circ} \mathrm{C}$ was added carefully over two portions and stirred for a further 0.5 hours till a white suspension was observed. Methyl (triphenylphosphoranylidene)acetate (54.0 g, 160 mmol) was added in one portion, followed by THF $(400 \mathrm{~mL})$ and the reaction mixture was allowed to warm to room temperature over $1 \mathrm{~h}$ and stirred for another $1 \mathrm{~h}$. The mixture was then allowed reflux for an additional 6 hours. The mixture was then cooled to room temperature, carefully diluted with $\mathrm{Et}_{2} \mathrm{O}(100 \mathrm{~mL})$ and $6 \mathrm{~N} \mathrm{HCl}(200$ $\mathrm{mL}$ ), stirred vigorously at room temperature till a clear biphasic separation was observed. The aqueous layer was extracted with $\mathrm{Et}_{2} \mathrm{O}$ (200 mL x 2), and the combined organic extracts were washed with saturated $\mathrm{NaHCO}_{3}$ solution (200 mL x 1) dried over anhydrous sodium sulfate, filtered and concentrated in vacuo. The triphenylphosphine oxide was removed by filtering through a short silica plug using hexane. The filtrate was concentrated and purified by flash chromatography (40:1 Hexane/Ethyl Acetate) to afford the desired E-enoate as colorless oil (8.7 g, 64\% yield; 73\% yield for mixture of isomers $E / Z, 92: 8)$ : $[\alpha]_{\mathrm{D}}^{22}=+2.0\left(c=1.1, \mathrm{CHCl}_{3}\right)$; FTIR (NaCl, neat): $1674 \mathrm{~cm}^{-1}$; ${ }^{1} \mathrm{H}$ NMR (400 MHz, $\left.\mathrm{CDCl}_{3}\right): \delta 6.95$ (dt, $\left.J=15.6,7.6 \mathrm{~Hz}, 1 \mathrm{H}\right), 5.81$ (d, $\left.J=15.6 \mathrm{~Hz}, 1 \mathrm{H}\right), 3.73$ (s, 3H), 2.23-2.16 (m, 1H), 2.05-2.00 (m, 1H), 1.66-1.59 (m, 1H), 1.35-1.24 (m, 3H), 1.15-1.12 (m, 1H), 0.91-0.85 (m, 6H); ${ }^{13} \mathrm{C}$ NMR (100 MHz, $\left.\mathrm{CDCl}_{3}\right): \delta 167.1(\mathrm{C}), 148.7(\mathrm{CH}), 121.9(\mathrm{CH}), 51.4\left(\mathrm{CH}_{3}\right), 39.7\left(\mathrm{CH}_{2}\right), 38.9\left(\mathrm{CH}_{2}\right), 32.2(\mathrm{CH}), 20.1$ $\left(\mathrm{CH}_{2}\right), 19.5\left(\mathrm{CH}_{3}\right), 14.2\left(\mathrm{CH}_{3}\right)$; HRMS (EI) calcd. for $\mathrm{C}_{10} \mathrm{H}_{18} \mathrm{O}_{2}$ 170.1307, [M] found 170.1305. 


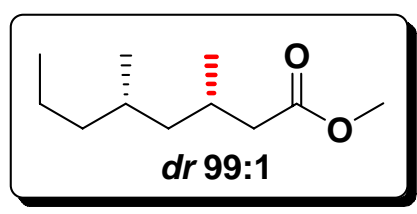

(3S,5S)-Methyl 3,5-dimethyloctanoate (14). In a round bottom flask equipped with septum and stirring bar, (S)Tol-BINAP (1.03 g, $1.52 \mathrm{mmol})$ and $\mathrm{CuI}(0.19 \mathrm{~g}, 1.00 \mathrm{mmol})$ were stirred in $\mathrm{CH}_{2} \mathrm{Cl}_{2}(100 \mathrm{~mL})$ for 20 minutes, concentrated in vacuo and then stirred in $t$-BuOMe $(200 \mathrm{~mL})$ till a bright yellow suspension was observed. The mixture was then cooled to $-20{ }^{\circ} \mathrm{C}$ and $\mathrm{MeMgBr}$ (85 mL, Aldrich 3.0 M solution in $\mathrm{Et}_{2} \mathrm{O}, 255 \mathrm{mmol}$ ) was added carefully into the reaction mixture. After stirring for 15 minutes, a solution of ( $S, E)$-Methyl 5-methyloct-2-enoate (8.51 g, $50 \mathrm{mmol})$ in $t$-BuOMe $\left(60 \mathrm{~mL}\right.$ ) was added dropwise over $10 \mathrm{~h}$ via syringe pump. After stirring at $-20{ }^{\circ} \mathrm{C}$ for another $1 \mathrm{~h}$, the reaction mixture was quenched with $\mathrm{MeOH}(50 \mathrm{~mL})$ and saturated $\mathrm{NH}_{4} \mathrm{Cl}$ solution $(150 \mathrm{~mL})$. The aqueous layer was extracted with diethyl ether $(200 \mathrm{~mL} \mathrm{x} \mathrm{3)}$ ) and the combined organic extracts were dried over anhydrous sodium sulfate, filtered and carefully concentrated in vacuo. The resulting residue was purified by flash chromatography (Hexane/Ethyl Acetate 30: 1) to afford the desired product as colorless oil (6.10 g, 66\% yield): $d r$ 99:1 in ${ }^{13} \mathrm{C}$ NMR using an average of two well resolved carbon signals and compared to a diastereomeric mixture (syn:anti 50:50) of methyl 3,5-dimethyloctanoate. Assuming an analogous reaction mechanism, synstereochemistry was assigned on the basis of enantiomeric Tol-BINAP ligands selected in each methyl addition leading to the syn-deoxypropionate unit. In other words, two iterative applications of $(S)$-Tol-BINAP as the ligand in each methyl addition should lead to the syn-diastereomer; $[\alpha]_{\mathrm{D}}{ }^{22}=+4.1\left(c=1.2, \mathrm{CHCl}_{3}\right)$; FTIR $(\mathrm{NaCl}$, neat): $1740 \mathrm{~cm}^{-1}$; ${ }^{1} \mathrm{H}$ NMR (400 MHz, $\mathrm{CDCl}_{3}$ ): $\delta 3.66$ (s, 3H), 2.34-2.27 (m, 1H), 2.08-2.00 (m, 2H), 1.51-1.43 (m, 1H), 1.40-1.19 (m, 4H), 1.09-0.97 (m, 2H), 0.92 (d, $J=6.1 \mathrm{~Hz}, 3 \mathrm{H}), 0.89-0.83$ (m, 6H); ${ }^{13} \mathrm{C}$ NMR $\left(100 \mathrm{MHz}, \mathrm{CDCl}_{3}\right): \delta$ $173.8(\mathrm{C}), 51.3\left(\mathrm{CH}_{3}\right), 44.6\left(\mathrm{CH}_{2}\right), 41.6\left(\mathrm{CH}_{2}\right), 38.9\left(\mathrm{CH}_{2}\right), 29.7(\mathrm{CH}), 27.8(\mathrm{CH}), 20.3\left(\mathrm{CH}_{3}\right), 20.0\left(\mathrm{CH}_{3}\right), 19.8$ $\left(\mathrm{CH}_{2}\right)$, $14.3\left(\mathrm{CH}_{3}\right)$; HRMS (EI) calcd. for $\mathrm{C}_{11} \mathrm{H}_{22} \mathrm{O}_{2}$ 186.1620, [M] $]^{+}$found 186.1618. 


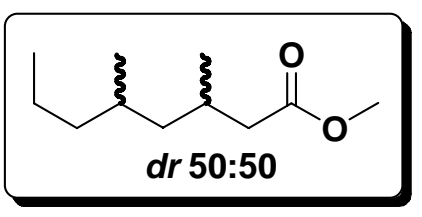

Methyl 3,5-dimethyloctanoate (14a). Diastereomeric mixtures were obtained using Gilman cuprates: Colorless oil: $d r$ 50:50 (syn:anti) was determined by ${ }^{13} \mathrm{C}$ NMR analysis and the syn:anti configuration assigned by analogy with the syn-diastereomer; FTIR ( $\mathrm{NaCl}$, neat): $v 1742 \mathrm{~cm}^{-1}$; ${ }^{1} \mathrm{H}$ NMR (400 MHz, $\mathrm{CDCl}_{3}$ ): $\delta 3.66$ (s, 3H), 2.34-2.27 (m, 1H), 2.08-2.00 (m, 2H), 1.51-1.43 (m, 1H), 1.40-1.19 (m, 4H), 1.09-0.97 (m, 2H), 0.92 (d, $J=6.1 \mathrm{~Hz}, 3 \mathrm{H})$, 0.89-0.83 (m, 6H); ${ }^{13} \mathrm{C}$ NMR (100 MHz, $\left.\mathrm{CDCl}_{3}\right)$ : syn-diastereomer (50\%) $\delta 173.8(\mathrm{C}), 51.3\left(\mathrm{CH}_{3}\right), 44.6\left(\mathrm{CH}_{2}\right)$, $41.6\left(\mathrm{CH}_{2}\right)$, $38.9\left(\mathrm{CH}_{2}\right)$, 29.7(CH), $27.8(\mathrm{CH}), 20.3\left(\mathrm{CH}_{3}\right), 20.0\left(\mathrm{CH}_{3}\right), 19.8\left(\mathrm{CH}_{2}\right), 14.3\left(\mathrm{CH}_{3}\right)$; anti-diastereomer (50\%) $\delta 173.6(\mathrm{C}), 51.3\left(\mathrm{CH}_{3}\right), 44.3\left(\mathrm{CH}_{2}\right), 42.4\left(\mathrm{CH}_{2}\right), 39.9\left(\mathrm{CH}_{2}\right), 29.7(\mathrm{CH}), 27.8(\mathrm{CH}), 20.0\left(\mathrm{CH}_{2}\right), 19.4\left(\mathrm{CH}_{3}\right)$, $19.2\left(\mathrm{CH}_{3}\right), 14.2\left(\mathrm{CH}_{3}\right)$; HRMS (EI) calcd. for $\mathrm{C}_{11} \mathrm{H}_{22} \mathrm{O}_{2}$ 186.1620, [M] found 186.1618. 


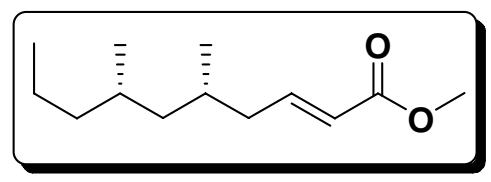

(5S,7S,E)-Methyl 5,7-dimethyldec-2-enoate (15). In a round bottom flask equipped with a stirring bar, (3S,5S)Methyl 3,5-dimethyloctanoate (3.96 g, $23 \mathrm{mmol}$ ) was dissolved in hexane (30 mL) and cooled to -78 ${ }^{\circ} \mathrm{C}$. DIBAL-H (Aldrich $1 \mathrm{M}$ solution in heptane, $40 \mathrm{~mL}, 40.0 \mathrm{mmol}$ ), pre-cooled to $-78^{\circ} \mathrm{C}$, was added carefully over several portions. After stirring for another $1.5 \mathrm{~h}, \mathrm{MeOH}(5 \mathrm{~mL})$, pre-cooled to $-78^{\circ} \mathrm{C}$ was added carefully over two portions and stirred for a further 0.5 hours till a white suspension was observed. Methyl (triphenylphosphoranylidene)acetate (14.0 g, $42 \mathrm{mmol})$ was added in one portion, followed by THF (90 mL) and the reaction mixture was allowed to warm to room temperature over $1 \mathrm{~h}$ and stirred for another $1 \mathrm{~h}$. The mixture was then allowed reflux for an additional 6 hours. The mixture was then cooled to room temperature, carefully diluted with $\mathrm{Et}_{2} \mathrm{O}(50 \mathrm{~mL})$ and $6 \mathrm{~N} \mathrm{HCl}(100 \mathrm{~mL})$, stirred vigorously at room temperature till a clear biphasic separation was observed. The aqueous layer was extracted with $\mathrm{Et}_{2} \mathrm{O}(50 \mathrm{~mL}$ x 2), and the combined organic extracts were washed with saturated $\mathrm{NaHCO}_{3}$ solution $(100 \mathrm{~mL}$ x 1$)$ dried over anhydrous sodium sulfate, filtered and concentrated in vacuo. The triphenylphosphine oxide was removed by filtering through a short silica plug using hexane. The filtrate was concentrated and purified by flash chromatography (60:1 Hexane/Ethyl Acetate) to afford the desired $E$-enoate as colorless oil (2.78 g, $58 \%$ yield; $72 \%$ yield for mixture of isomers $E / Z, 90: 10):[\alpha]_{\mathrm{D}}{ }^{22}=$ +2.4 ( $c=1.0, \mathrm{CHCl}_{3}$ ); FTIR (NaCl, neat): $\left.1672 \mathrm{~cm}^{-1} ;{ }^{1} \mathrm{H} \mathrm{NMR} \mathrm{(400} \mathrm{MHz,} \mathrm{CDCl}_{3}\right): \delta 6.95$ (dt, $\left.J=15.7,7.7 \mathrm{~Hz}, 1 \mathrm{H}\right)$, $5.80(\mathrm{~d}, J=15.7,1 \mathrm{H}), 3.73(\mathrm{~s}, 3 \mathrm{H}), 2.25-2.18(\mathrm{~m}, 1 \mathrm{H}), 2.01-1.94(\mathrm{~m}, 1 \mathrm{H}), 1.74-1.69(\mathrm{~m}, 1 \mathrm{H}), 1.52-1.47$ (m, $1 \mathrm{H})$, 1.34-1.20 (m, 4H), 1.07-0.93 (m, 2H), 0.89-0.84 (m, 9H); ${ }^{13} \mathrm{C}$ NMR (100 MHz, $\left.\mathrm{CDCl}_{3}\right): \delta 166.9(\mathrm{C}), 148.5(\mathrm{CH})$, $121.9(\mathrm{CH}), 51.2\left(\mathrm{CH}_{3}\right), 44.5\left(\mathrm{CH}_{2}\right) 39.4\left(\mathrm{CH}_{2}\right), 39.0\left(\mathrm{CH}_{2}\right), 29.8(\mathrm{CH}), 29.7(\mathrm{CH}), 20.0\left(\mathrm{CH}_{3}\right), 20.0\left(\mathrm{CH}_{3}\right), 19.9$ $\left(\mathrm{CH}_{3}\right), 14.3\left(\mathrm{CH}_{3}\right)$; HRMS (EI) calcd. for $\mathrm{C}_{13} \mathrm{H}_{24} \mathrm{O}_{2}$ 212.1776, [M] $]^{+}$found 212.1777. 


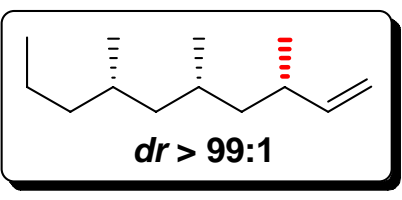

(3S,5S,7S)-3,5,7-trimethyldec-1-ene (16). In a round bottom flask equipped with septum and stirring bar, $(S)$-TolBINAP $(0.244 \mathrm{~g}, 0.36 \mathrm{mmol})$ and $\mathrm{CuI}(0.047 \mathrm{~g}, 0.24 \mathrm{mmol})$ were stirred in $\mathrm{CH}_{2} \mathrm{Cl}_{2}(30 \mathrm{~mL})$ for 20 minutes, concentrated in vacuo and then stirred in $t$-BuOMe $(50 \mathrm{~mL})$ till a bright yellow suspension was observed. The mixture was then cooled to $-20{ }^{\circ} \mathrm{C}$ and $\mathrm{MeMgBr}\left(20 \mathrm{~mL}\right.$, Aldrich $3.0 \mathrm{M}$ solution in $\mathrm{Et}_{2} \mathrm{O}, 60 \mathrm{mmol}$ ) was added carefully into the reaction mixture. After stirring for 15 minutes, a solution of (5S,7S,E)-Methyl 5,7-dimethyldec-2enoate (2.58 g, $12.2 \mathrm{mmol})$ in $t$-BuOMe $(15 \mathrm{~mL})$ was added dropwise over $3 \mathrm{~h}$ via syringe pump. After stirring at $20^{\circ} \mathrm{C}$ for another $1 \mathrm{~h}$, the reaction mixture was cooled to $-78^{\circ} \mathrm{C}$ and bromine $(3.5 \mathrm{~mL}, 4.5 \mathrm{mmol})$ was added slowly. The reaction mixture was allowed to warm to $-40^{\circ} \mathrm{C}$ and then $\mathrm{MeOH}(3 \mathrm{~mL})$ followed by saturated $\mathrm{NH}_{4} \mathrm{Cl}$ solution $(15 \mathrm{~mL})$ was added. The aqueous layer was extracted with diethyl ether $(20 \mathrm{~mL} \times 2)$ and the combined organic extracts were washed with saturated $\mathrm{NaS}_{2} \mathrm{O}_{3}$ solution (30 mL x 2) dried over anhydrous sodium sulphate, filtered and carefully concentrated in vacuo. The residual crude intermediate was passed through a short silica plug using 30:1 Hexane/Ethyl Acetate, and used for next step without further purification. The intermediate was dissolved in hexane $(20 \mathrm{~mL})$, cooled to $-78^{\circ} \mathrm{C}$ and DIBAL-H $(20 \mathrm{~mL})$ was added. The reaction mixture was allowed to warm to $-40^{\circ} \mathrm{C}$ and stirred for another $2 \mathrm{~h}$ before saturated $\mathrm{NH}_{4} \mathrm{Cl}$ solution $(5 \mathrm{~mL}), \mathrm{Et}_{2} \mathrm{O}(20 \mathrm{~mL})$ and $6 \mathrm{~N} \mathrm{HCl}(10 \mathrm{~mL})$ were added. The mixture was stirred vigorously at room temperature till a clear biphasic separation was observed. The aqueous layer was extracted with $\mathrm{Et}_{2} \mathrm{O}(20 \mathrm{~mL}$ x 2), and the combined organic extracts were washed with saturated $\mathrm{NaHCO}_{3}$ solution $(40 \mathrm{~mL} \times 1)$ dried over anhydrous sodium sulfate, filtered and concentrated in vacuo. The resulting residue was passed through a short silica plug using 4:1 Hexane/Ethyl Acetate, and used for next step without further purification. The intermediate was dissolved in THF (90 mL), after which Zn dust (5.30 g) and glacial acetic acid $(10.0 \mathrm{~mL})$ were added. The mixture was refluxed for $16 \mathrm{~h}$, cooled, filtered and diluted with $\mathrm{Et}_{2} \mathrm{O}$ (30 mL). The combined organic extracts were washed with $1 \mathrm{~N} \mathrm{NaOH} \mathrm{(40} \mathrm{mL} \mathrm{x} \mathrm{1)} \mathrm{dried} \mathrm{over} \mathrm{anhydrous} \mathrm{sodium}$ sulfate, filtered and concentrated in vacuo. The resulting residue was purified by flash chromatography (Hexane $100 \%)$ to afford the desired product as colorless oil ( $0.97 \mathrm{~g}, 44 \%$ yield), contains a trace amount of non-separable impurities: $d r>99: 1$ in ${ }^{13} \mathrm{C}$ NMR using an average of three well resolved carbon signals and compared to a diastereomeric mixture ( $d r$ 30:26:22:22) of methyl 3,5-dimethyloctanoate. Assuming an analogous reaction mechanism, syn,syn-stereochemistry was assigned on the basis of enantiomeric Tol-BINAP ligands selected in each methyl addition leading to the syn,syn-deoxypropionate unit. In other words, two iterative applications of $(S)$-TolBINAP as the ligand in each methyl addition should lead to the syn,syn-diastereomer; $[\alpha]_{\mathrm{D}}^{22}=+5.3(c=0.9$, $\mathrm{CHCl}_{3}$ ); FTIR (NaCl, neat): 1944, $963 \mathrm{~cm}^{-1}$; ${ }^{1} \mathrm{H}$ NMR (400 MHz, $\mathrm{CDCl}_{3}$ ): $\delta 5.62$ (dt, $\left.J=17.2,8.3 \mathrm{~Hz}, 1 \mathrm{H}\right), 4.96$ (dt, $J=17.2,0.9 \mathrm{~Hz}, 1 \mathrm{H}), 4.91$ (dd, $J=10.2,1.4 \mathrm{~Hz}, 1 \mathrm{H}), 2.29-2.18$ (m, 1H), 1.58-1.46 (m, 2H), 1.38-1.14 (m, 7H), 1.08-1.00 (m, 1H), 0.98 (d, $J=6.7 \mathrm{~Hz}, 3 \mathrm{H}), 0.93-0.81$ (m, 9H); ${ }^{13} \mathrm{C}$ NMR (100 MHz, $\left.\mathrm{CDCl}_{3}\right): \delta 144.8(\mathrm{CH}), 112.5$ $\left(\mathrm{CH}_{2}\right), 45.7\left(\mathrm{CH}_{2}\right), 44.3\left(\mathrm{CH}_{2}\right), 39.3\left(\mathrm{CH}_{2}\right), 35.6(\mathrm{CH}), 29.7(\mathrm{CH}), 27.6(\mathrm{CH}), 21.5\left(\mathrm{CH}_{3}\right), 20.2\left(\mathrm{CH}_{3}\right), 20.1\left(\mathrm{CH}_{3}\right)$, $20.0\left(\mathrm{CH}_{2}\right), 14.4\left(\mathrm{CH}_{3}\right)$; HRMS (EI) calcd. for $\mathrm{C}_{13} \mathrm{H}_{26}$ 182.2035, [M] found 182.2032. 


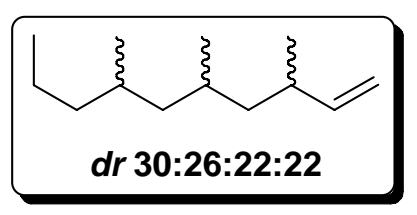

3,5,7-trimethyldec-1-ene (16a). Colorless oil: FTIR ( $\mathrm{NaCl}$, neat): 1938, $959 \mathrm{~cm}^{-1}$; ${ }^{1} \mathrm{H}$ NMR (400 MHz, CDCl 3 ): $\delta$ 5.77-5.56 (m, 1H), 4.98-4.87 (m, 2H), 2.29-2.18 (m, 1H), 1.61-1.45 (m, 2H), 1.38-1.02 (m, 8H), 1.01-0.94 (m, 3H), 0.90-0.79 (m, 9H); ${ }^{13} \mathrm{C}$ NMR (100 MHz, CDCl $)$ : syn, syn-diastereomer (30\%) $\delta 144.8(\mathrm{CH}), 112.5\left(\mathrm{CH}_{2}\right), 45.7$ $\left(\mathrm{CH}_{2}\right), 44.3\left(\mathrm{CH}_{2}\right), 39.3\left(\mathrm{CH}_{2}\right), 35.6(\mathrm{CH}), 29.7(\mathrm{CH}), 27.6(\mathrm{CH}), 21.5\left(\mathrm{CH}_{3}\right), 20.2\left(\mathrm{CH}_{3}\right), 20.1\left(\mathrm{CH}_{3}\right), 20.0\left(\mathrm{CH}_{2}\right)$, 14.4 ( $\left(\mathrm{CH}_{3}\right)$; Diastereomer $2(27 \%) \delta 145.6(\mathrm{CH}), 111.8\left(\mathrm{CH}_{2}\right)$, $45.4\left(\mathrm{CH}_{2}\right), 44.7\left(\mathrm{CH}_{2}\right), 39.0\left(\mathrm{CH}_{2}\right), 35.4(\mathrm{CH}), 29.7$ (CH), $27.6(\mathrm{CH}), 20.3\left(\mathrm{CH}_{3}\right), 20.2\left(\mathrm{CH}_{2}\right), 20.1\left(\mathrm{CH}_{3}\right), 19.8\left(\mathrm{CH}_{3}\right), 14.4\left(\mathrm{CH}_{3}\right)$; Diastereomer $3(22 \%) \delta 145.4(\mathrm{CH})$, 112.3 $\left(\mathrm{CH}_{2}\right), 45.3\left(\mathrm{CH}_{2}\right), 44.4\left(\mathrm{CH}_{2}\right), 40.2\left(\mathrm{CH}_{2}\right), 35.2(\mathrm{CH}), 29.7(\mathrm{CH}), 27.6(\mathrm{CH}), 20.5\left(\mathrm{CH}_{3}\right), 20.1\left(\mathrm{CH}_{2}\right), 20.1$ $\left(\mathrm{CH}_{3}\right), 19.5\left(\mathrm{CH}_{3}\right), 14.4\left(\mathrm{CH}_{3}\right)$; Diastereomer $4(21 \%) \delta 145.0(\mathrm{CH}), 112.0\left(\mathrm{CH}_{2}\right), 45.3\left(\mathrm{CH}_{2}\right), 44.3\left(\mathrm{CH}_{2}\right), 40.5$ $\left(\mathrm{CH}_{2}\right)$, $35.1(\mathrm{CH}), 29.8(\mathrm{CH}), 27.6(\mathrm{CH}), 21.13\left(\mathrm{CH}_{3}\right), 20.2\left(\mathrm{CH}_{2}\right), 20.1\left(\mathrm{CH}_{3}\right), 19.4\left(\mathrm{CH}_{3}\right), 14.4\left(\mathrm{CH}_{3}\right)$; HRMS (EI) calcd. for $\mathrm{C}_{13} \mathrm{H}_{26}$ 182.2035, [M] found 182.2032. 


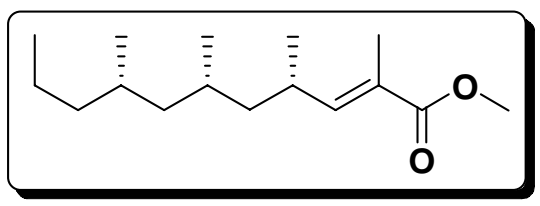

$(4 S, 6 S, 8 S, E)$-Methyl 2,4,6,8-tetramethylundec-2-enoate(17). In a round bottom flask equipped with a stirring bar, a stirred solution of (3S,5S,7S)-3,5,7-trimethyldec-1-ene $(0.42 \mathrm{~g}, 2.3 \mathrm{mmol})$ in $\mathrm{CH}_{2} \mathrm{Cl}_{2}(4 \mathrm{~mL})$ was cooled to $-78^{\circ} \mathrm{C}$ and purged with oxygen and then ozone for $20 \mathrm{~min}$. The stirred solution was purged with oxygen for 5 min before dimethyl sulfide $(0.6 \mathrm{~mL})$ was added. The solution was stirred for another $15 \mathrm{~min}$ before 1methoxycarbonylethylidenetriphenylphosphorane (2.40 g, $6.9 \mathrm{mmol})$ was added in one portion. The reaction mixture was allowed to stir at room temperature for $1 \mathrm{~h}$ and then refluxed for $14 \mathrm{~h}$. The reaction mixture was allowed to cool and concentrated in vacuo. The triphenylphosphine oxide was removed by passing the residue through a short silica plug using hexane. The filtrate was concentrated and purified by flash chromatography (40:1 Hexane/Ethyl Acetate) to afford the desired $E$-enoate $(0.24 \mathrm{~g}, 42 \%$ yield $)$ as colorless oil: $[\alpha]_{\mathrm{D}}^{22}=+17.8(c=0.8$, $\mathrm{CHCl}_{3}$ ); FTIR (NaCl, neat): $1711 \mathrm{~cm}^{-1}$; ${ }^{1} \mathrm{H}$ NMR (400 MHz, $\mathrm{CDCl}_{3}$ ): $\delta 6.49$ (dd, $J=10.1,1.2 \mathrm{~Hz}, 1 \mathrm{H}$ ), 3.71 (s, $3 \mathrm{H}), 2.66-2.54$ (m, 1H), 1.84 (d, $J=1.2 \mathrm{~Hz}, 3 \mathrm{H}), 1.51-1.40$ (m, 1H), 1.39-1.26 (m, 2H), 1.25-0.99 (m, $4 \mathrm{H}), 0.96$ (d, $J=6.6 \mathrm{~Hz}, 3 \mathrm{H}), 0.89-0.78$ (m, 12H); ${ }^{13} \mathrm{C} \mathrm{NMR}\left(100 \mathrm{MHz}, \mathrm{CDCl}_{3}\right): \delta 168.8(\mathrm{C}), 148.5(\mathrm{CH}), 125.9(\mathrm{C}), 51.6\left(\mathrm{CH}_{3}\right)$, $45.6\left(\mathrm{CH}_{2}\right), 44.3\left(\mathrm{CH}_{2}\right), 39.3\left(\mathrm{CH}_{2}\right), 30.9(\mathrm{CH}), 29.6(\mathrm{CH}), 28.1(\mathrm{CH}), 20.6\left(\mathrm{CH}_{3}\right), 20.4\left(\mathrm{CH}_{3}\right), 20.0\left(\mathrm{CH}_{3}\right), 20.0$ $\left(\mathrm{CH}_{2}\right), 14.4\left(\mathrm{CH}_{3}\right), 12.5\left(\mathrm{CH}_{3}\right)$; HRMS (EI) calcd. for $\mathrm{C}_{16} \mathrm{H}_{30} \mathrm{O}_{2} 254.2246$, [M] $]^{+}$found 254.2245. 


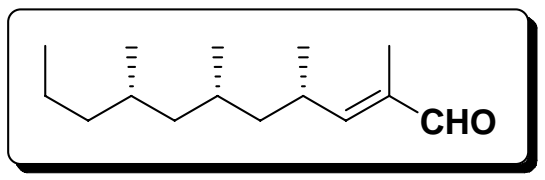

Siphonarienal (10). To a stirred solution of (4S,6S,8S,E)-Methyl 2,4,6,8-tetramethylundec-2-enoate (0.045 g, 0.18 $\mathrm{mmol})$ in hexane $(0.40 \mathrm{~mL})$ at $-78^{\circ} \mathrm{C}$ was added DIBAL-H (1 M solution in heptane, $0.37 \mathrm{~mL}, 0.37 \mathrm{mmol}$,). After stirring for another $1.5 \mathrm{~h}$ at $0^{\circ} \mathrm{C}$, saturated $\mathrm{NH}_{4} \mathrm{Cl}$ solution $(1 \mathrm{~mL}), \mathrm{Et}_{2} \mathrm{O}(2 \mathrm{~mL})$ and $6 \mathrm{~N} \mathrm{HCl}(1 \mathrm{~mL})$, were added and the reaction mixture were stirred vigorously at room temperature till a clear biphasic separation was observed. The aqueous layer was extracted with $\mathrm{Et}_{2} \mathrm{O}$ ( $2 \mathrm{~mL}$ x 2), and the combined organic extracts were washed with saturated $\mathrm{NaHCO}_{3}$ solution (4 mL x 1) dried over anhydrous sodium sulfate, filtered and concentrated in vacuo. Without further purification, the alcohol containing residue was added to a solution of 2-Iodoxybenzoic acid (0.0062 g, $0.22 \mathrm{mmol})$ in DMSO $(0.20 \mathrm{~mL})$ at room temperature. The reaction mixture was stirred for $4 \mathrm{~h}$, by $\mathrm{Et}_{2} \mathrm{O}$ ( $2 \mathrm{~mL} \times 2)$ and $\mathrm{H}_{2} \mathrm{O}(2 \mathrm{~mL}$ ) were added. The reaction mixture was stirred vigorously and then filtered. The combined organic extracts were dried over anhydrous sodium sulfate, filtered and concentrated in vacuo. The resulting residue was purified by flash chromatography (30:1 Hexane/Ethyl Acetate) to afford the desired product as colorless oil $\left(0.024 \mathrm{~g}, 63 \%\right.$ yield): $[\alpha]_{\mathrm{D}}{ }^{22}=+16.1\left(c=1.1, \mathrm{CHCl}_{3}\right)$; FTIR (NaCl, neat): $1671 \mathrm{~cm}^{-1} ;{ }^{1} \mathrm{H}$ NMR (400 MHz, $\mathrm{CDCl}_{3}$ ): $\delta 9.39$ (s, 1H), 6.21 (d, $\left.J=10.0 \mathrm{~Hz}, 1 \mathrm{H}\right), 2.88-2.77$ (m, 1H), 1.67 (s, 3H), 1.52-1.26 (m, 3H), 1.25-1.12 (m, 4H), 1.04 (d, $J=6.6 \mathrm{~Hz}, 3 \mathrm{H}), 0.97-0.79$ (m, 12H); ${ }^{13} \mathrm{C}$ NMR (100 MHz, $\left.\mathrm{CDCl}_{3}\right): \delta 195.6(\mathrm{CH})$, 160.8(CH), $138.0(\mathrm{C}), 45.6\left(\mathrm{CH}_{2}\right), 44.2\left(\mathrm{CH}_{2}\right), 39.2\left(\mathrm{CH}_{2}\right), 31.2(\mathrm{CH}), 29.6(\mathrm{CH}), 28.2(\mathrm{CH}), 20.5\left(\mathrm{CH}_{3}\right), 20.3$ $\left(\mathrm{CH}_{3}\right), 20.0\left(\mathrm{CH}_{3}\right), 20.0\left(\mathrm{CH}_{2}\right), 14.4\left(\mathrm{CH}_{3}\right), 9.4\left(\mathrm{CH}_{3}\right)$; HRMS (EI) calcd. for $\mathrm{C}_{15} \mathrm{H}_{28} \mathrm{O} 224.2140$, $[\mathrm{M}+\mathrm{H}]^{+}$found 225.2220 . 


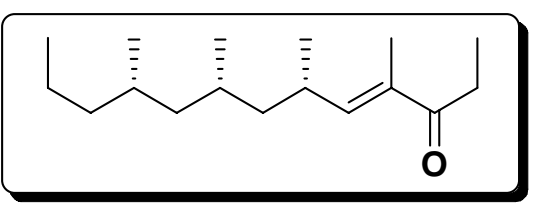

Siphonarienone (11). In a round bottom flask equipped with a stirring bar, a stirred slurry of $(4 S, 6 S, 8 S, E)$-Methyl 2,4,6,8-tetramethylundec-2-enoate $(0.025 \mathrm{~g}, 0.10 \mathrm{mmol})$ and MeONHMe.HCl (0.030 g, $0.30 \mathrm{mmol})$ in THF (0.5 $\mathrm{mL}$ ) at $-20^{\circ} \mathrm{C}$ was added $i$-PrgMgCl solution (2M solution in THF, $0.22 \mathrm{~mL}, 0.44 \mathrm{mmol}$ ) dropwise over $5 \mathrm{~min}$. After $1.5 \mathrm{~h}$, the reaction mixture was partitioned between saturated $\mathrm{NH}_{4} \mathrm{Cl}$ solution $(2 \mathrm{~mL})$ and $\mathrm{Et}_{2} \mathrm{O}(2 \mathrm{~mL})$, extracted with $\mathrm{Et}_{2} \mathrm{O}$ (2 $\mathrm{mL} \times 1$ ). The combined organic extracts were washed with brine (5 mL x 1), dried over anhydrous sodium sulfate, filtered and concentrated in vacuo. Without further purification, the solution of Weinreb amide containing residue was stirred in THF $(0.30 \mathrm{~mL})$ at $0^{\circ} \mathrm{C}$ before $\mathrm{EtMgBr}\left(3 \mathrm{M}\right.$ solution in $\mathrm{Et}_{2} \mathrm{O}, 0.17 \mathrm{~mL}, 0.51$ mmol) was added. The reaction mixture was allowed to stir at room temperature for $16 \mathrm{~h}$ before it was partitioned between saturated $\mathrm{NH}_{4} \mathrm{Cl}$ solution ( $2 \mathrm{~mL}$ ) and $\mathrm{Et}_{2} \mathrm{O}(2 \mathrm{~mL})$, extracted with $\mathrm{Et}_{2} \mathrm{O}$ (2 mL x 1). The combined organic extracts were washed with brine ( $5 \mathrm{~mL}$ x 1), dried over anhydrous sodium sulphate, filtered and concentrated in vacuo. The resulting residue was purified by flash chromatography (30:1 Hexane/Ethyl Acetate) to afford the desired product as colorless oil (0.017 g, $67 \%$ yield): $[\alpha]_{\mathrm{D}}^{22}=+16.5\left(c=0.85, \mathrm{CHCl}_{3}\right)$; FTIR (NaCl, neat): 1674 $\mathrm{cm}^{-1} ;{ }^{1} \mathrm{H}$ NMR (400 MHz, $\mathrm{CDCl}_{3}$ ): $\delta 6.33$ (d, $J=9.8 \mathrm{~Hz}, 1 \mathrm{H}$ ), 2.67 (q, $J=7.5 \mathrm{~Hz}, 2 \mathrm{H}$ ), 2.79-2.58 (m, $1 \mathrm{H}$ ), 1.80 (s, 3H), 1.55-1.41 (m, 3H), 1.39-1.26 (m, 3H), 1.24-1.16 (m, 2H), 1.15-1.04 (m, 2H), 1.00 (d, $J=6.6 \mathrm{~Hz}, 3 \mathrm{H}), 0.94-$ $0.76(\mathrm{~m}, 12 \mathrm{H}) ;{ }^{13} \mathrm{C}$ NMR (100 MHz, $\left.\mathrm{CDCl}_{3}\right): \delta$ 202.9(C), 148.3(CH), $135.4(\mathrm{C}), 45.6\left(\mathrm{CH}_{2}\right), 44.7\left(\mathrm{CH}_{2}\right), 39.3$ ( $\left.\mathrm{CH}_{2}\right)$, $31.2(\mathrm{CH}), 30.4(\mathrm{CH}), 29.6(\mathrm{CH}), 28.3(\mathrm{CH}), 20.7\left(\mathrm{CH}_{3}\right), 20.5\left(\mathrm{CH}_{3}\right), 19.9\left(\mathrm{CH}_{3}\right), 19.9\left(\mathrm{CH}_{2}\right), 14.4\left(\mathrm{CH}_{3}\right)$, $11.5\left(\mathrm{CH}_{3}\right), 9.0\left(\mathrm{CH}_{3}\right)$; HRMS (EI) calcd. for $\mathrm{C}_{17} \mathrm{H}_{32} \mathrm{O} 252.2453[\mathrm{M}]^{+}$found 252.2450. 


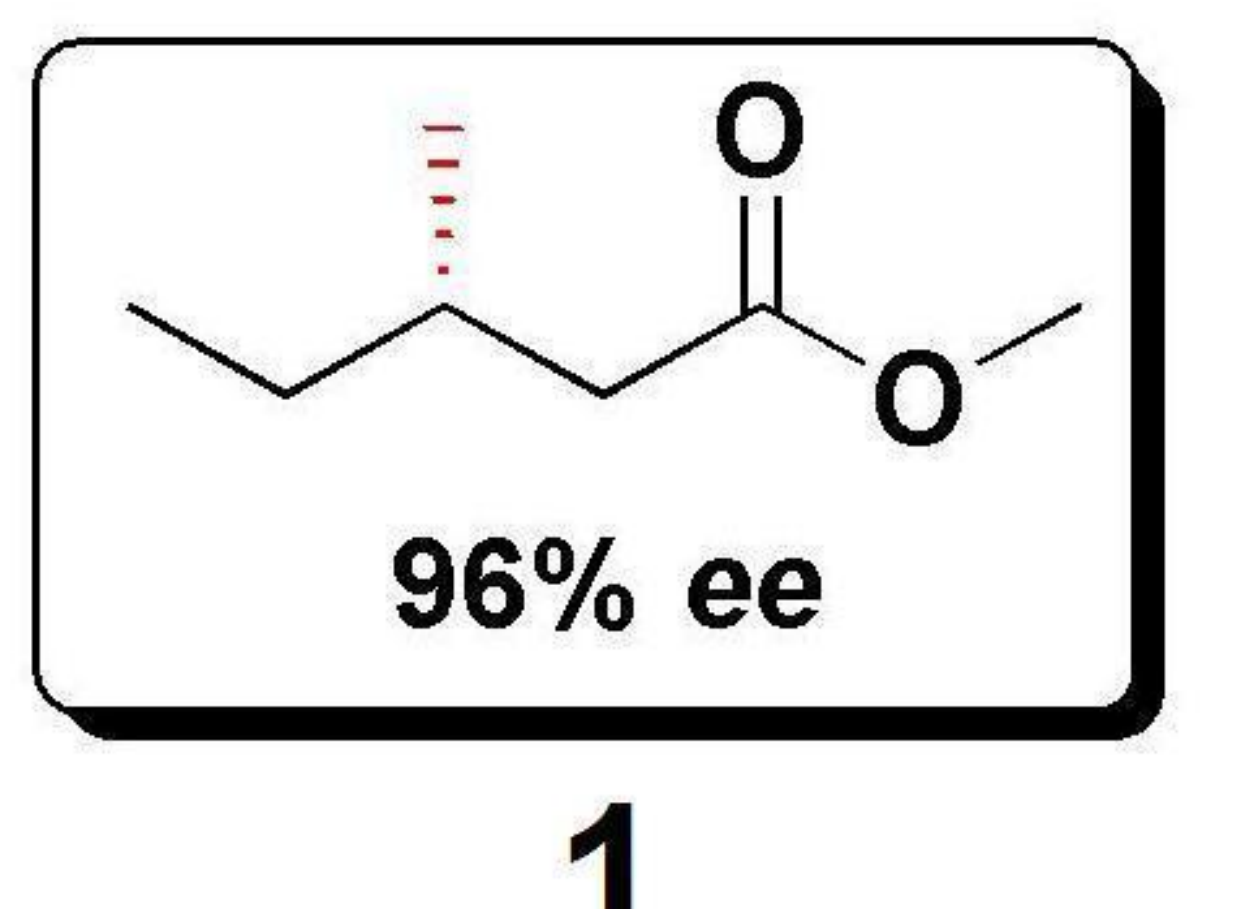

$m \infty r+m i n$

$m m \infty \sim \infty \Omega^{2}$

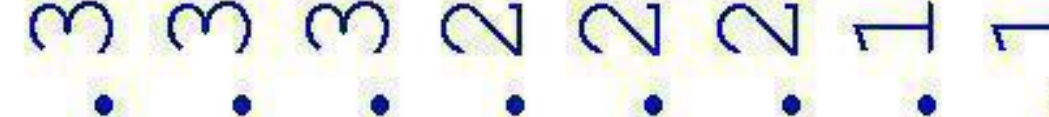

다

111111

नㄷํ유ํำ

न ब $\infty \infty$

$\dot{0} \dot{0} \dot{0} \dot{0} 0$
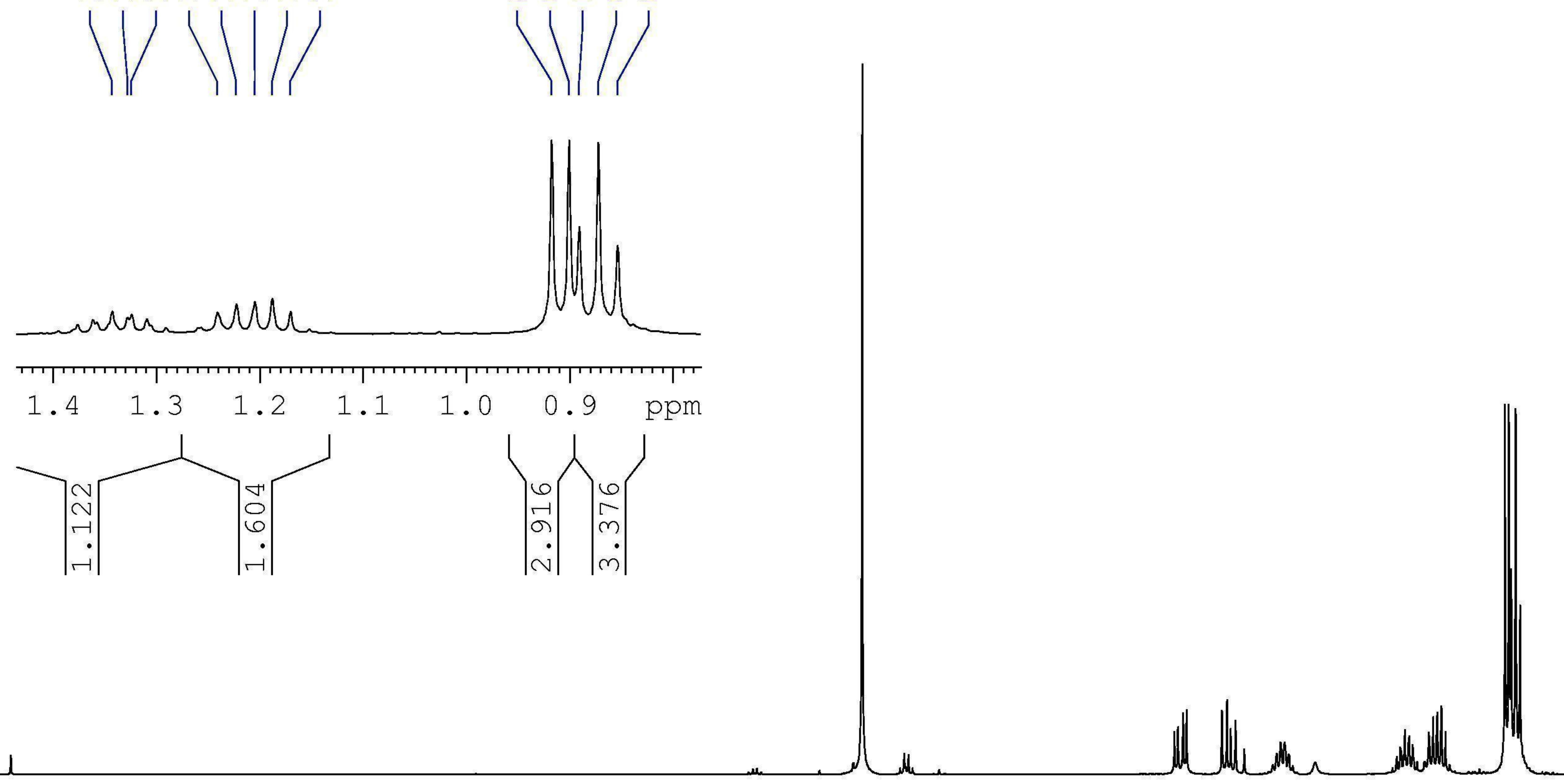

\section{S24}



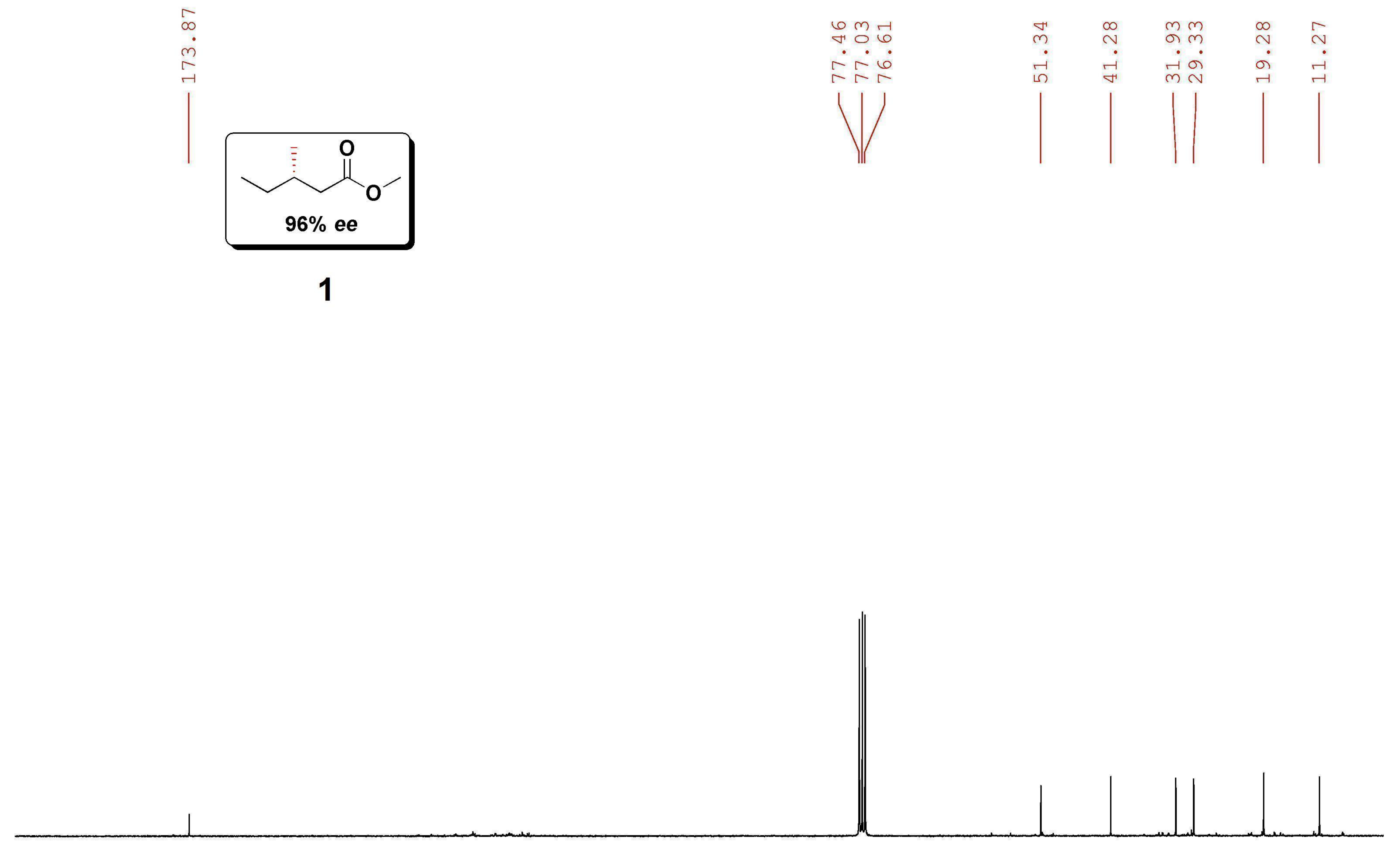

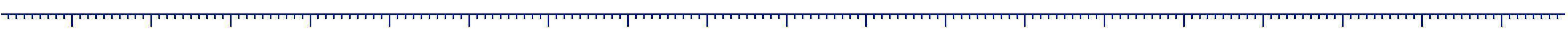

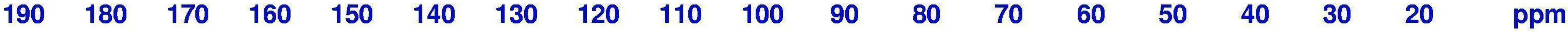
S25 

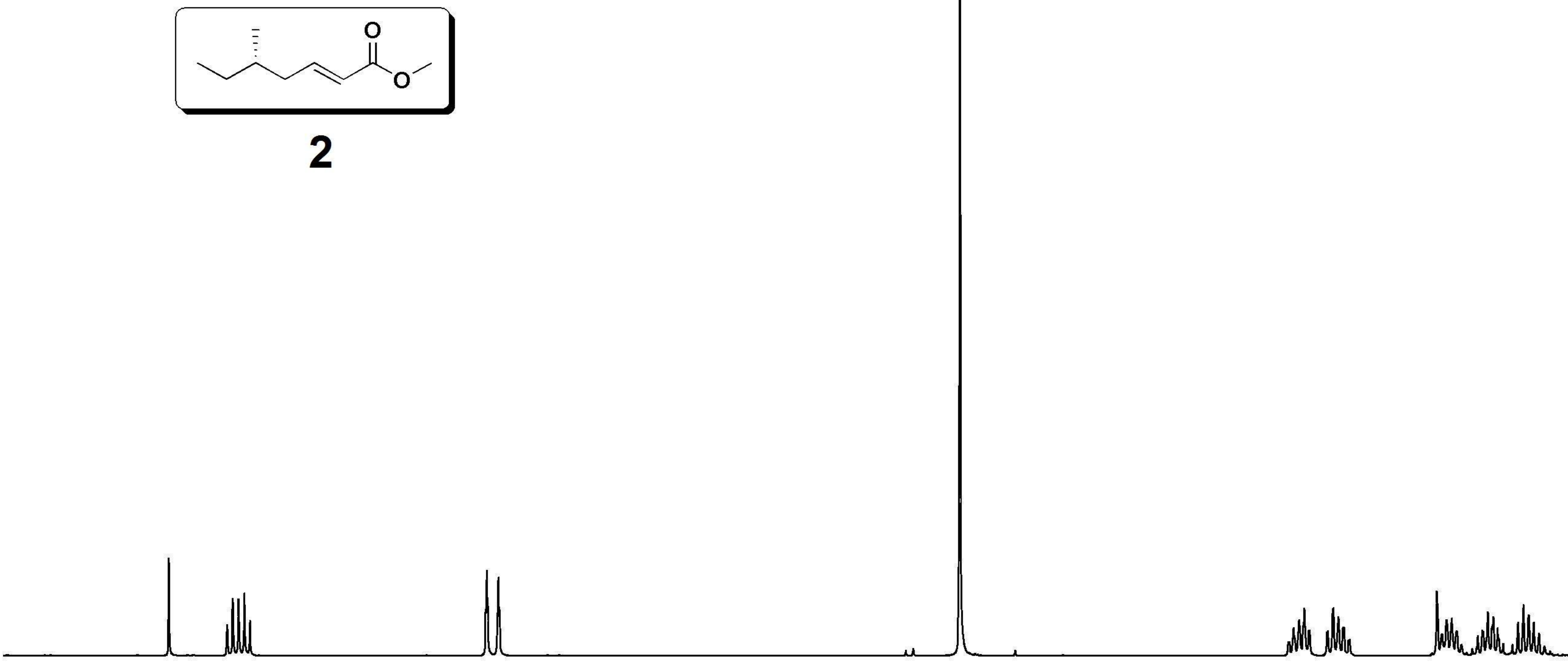

$\begin{array}{llll}7.5 & 7.0 & 6.5 & 6.0\end{array}$

$\left|\begin{array}{l}0 \\ \hdashline \\ \end{array}\right|$

4.5

4.0

3.5

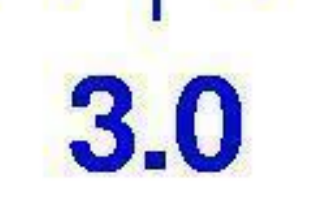

2.5

$2.0 \quad 1.5 \quad 1.0$

$\begin{array}{llll}.0 & 0.5 & 0.0 & \mathrm{ppm}\end{array}$ |co

|m||

|

S26 


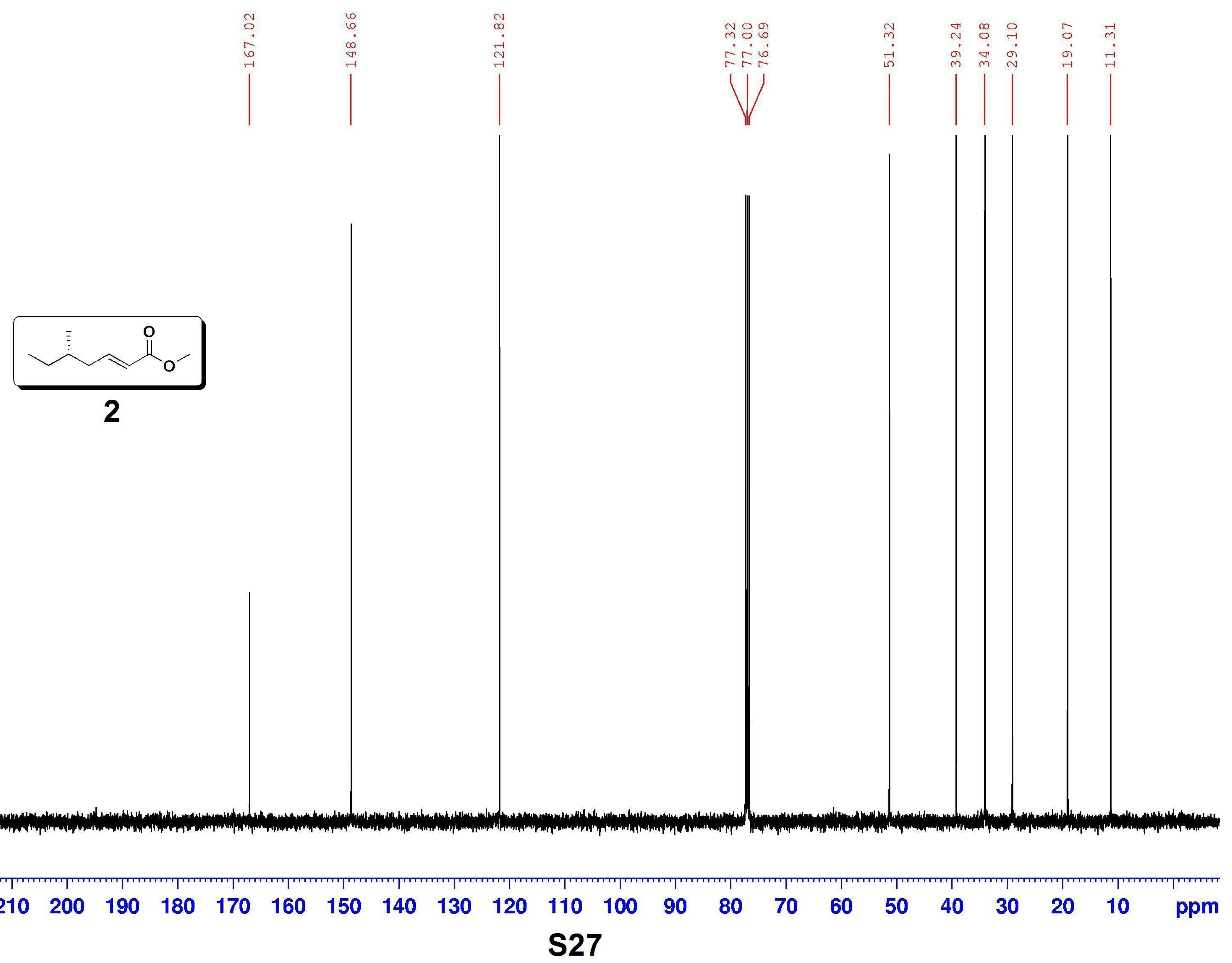




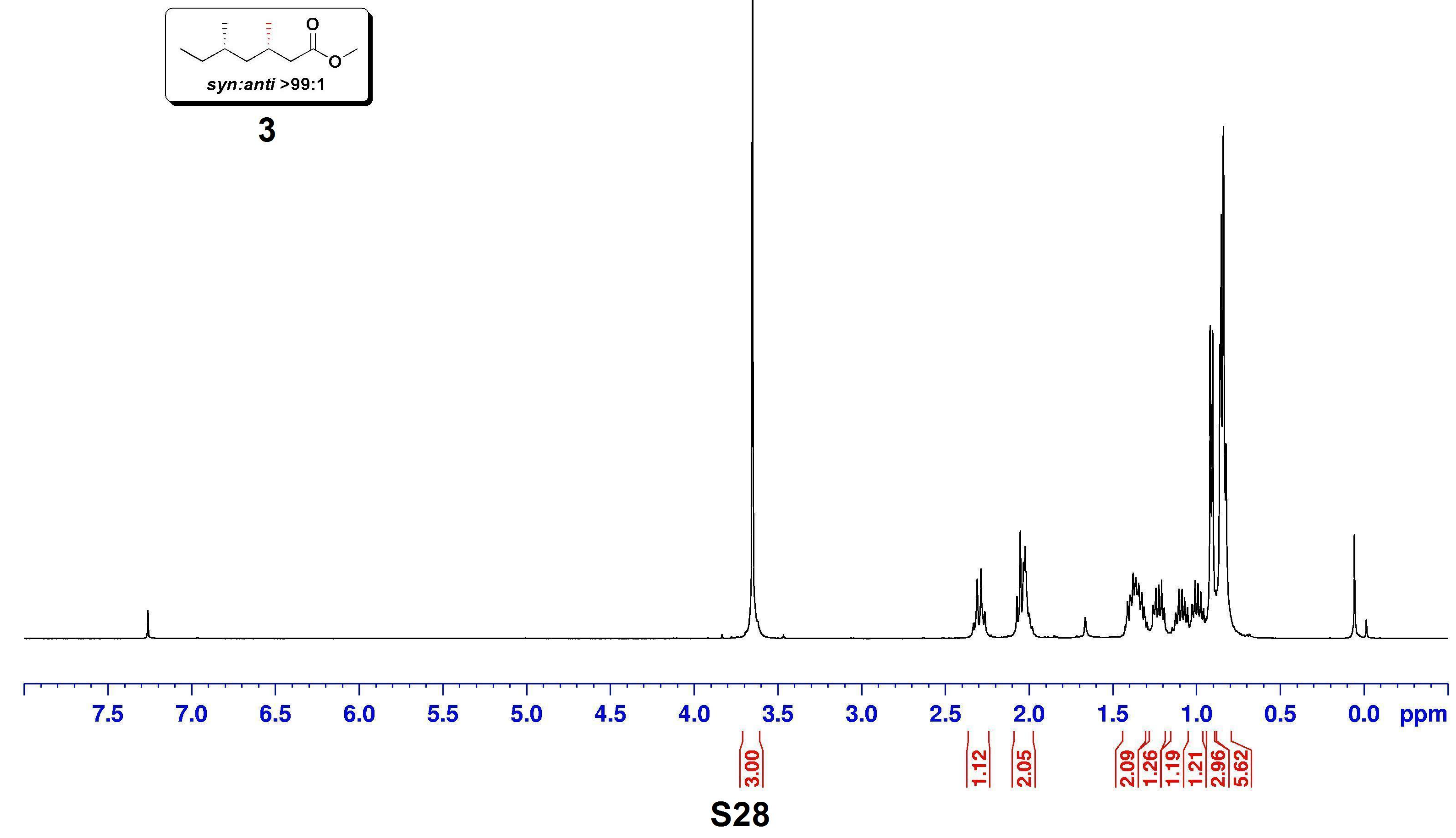




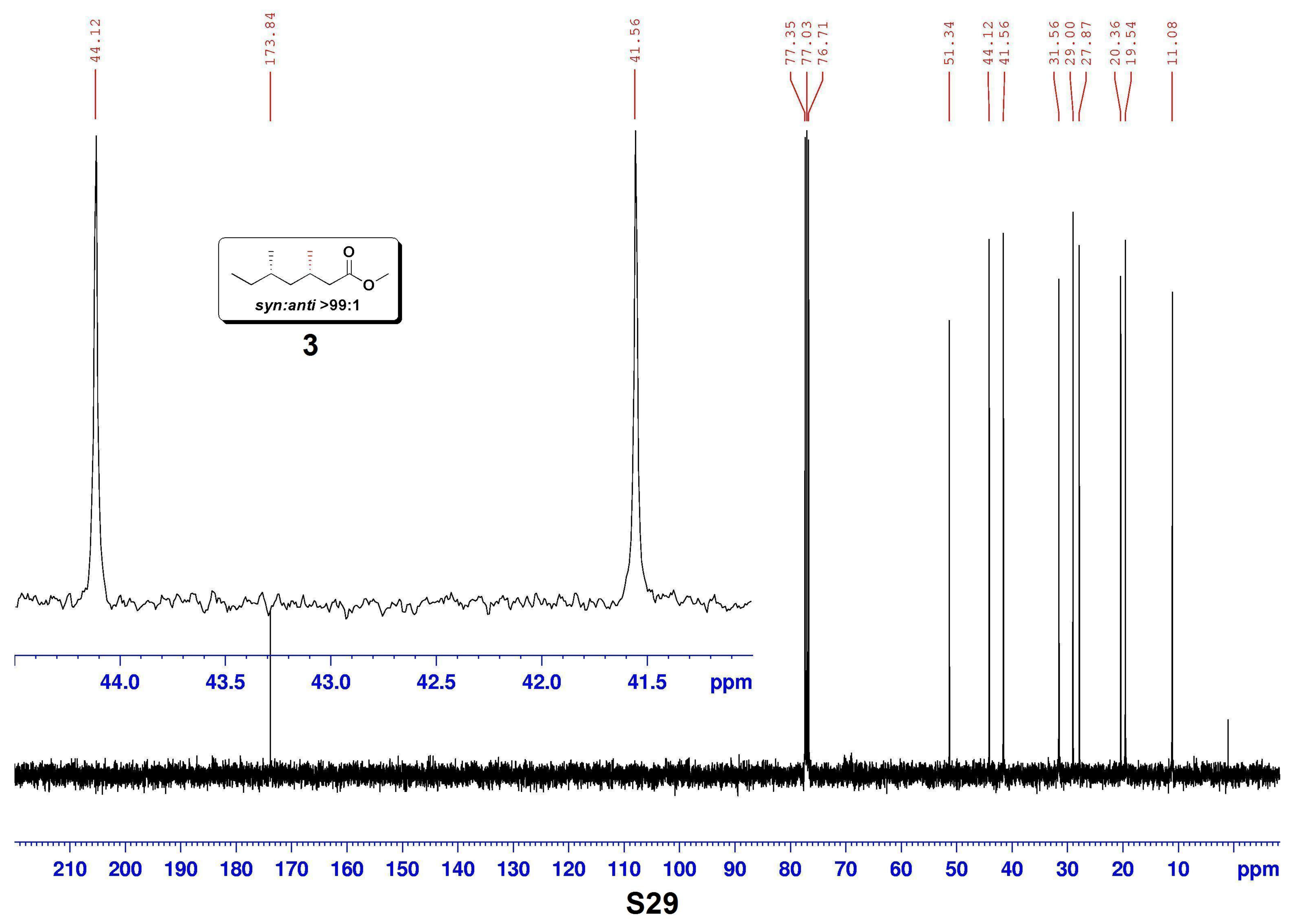




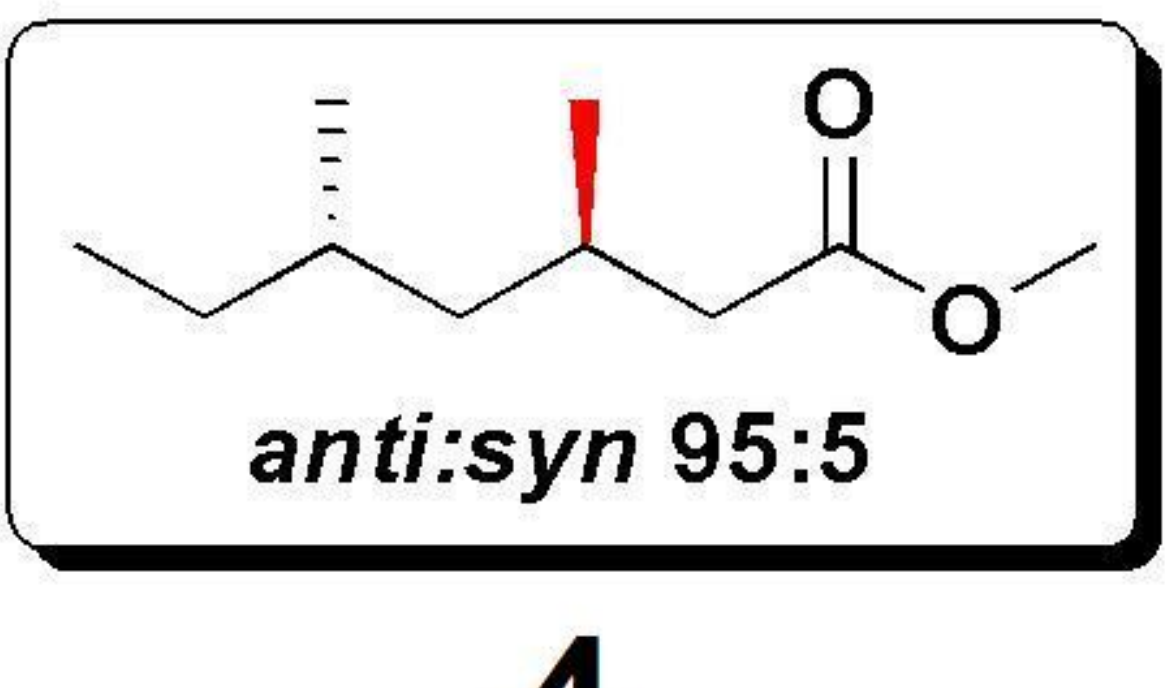

4

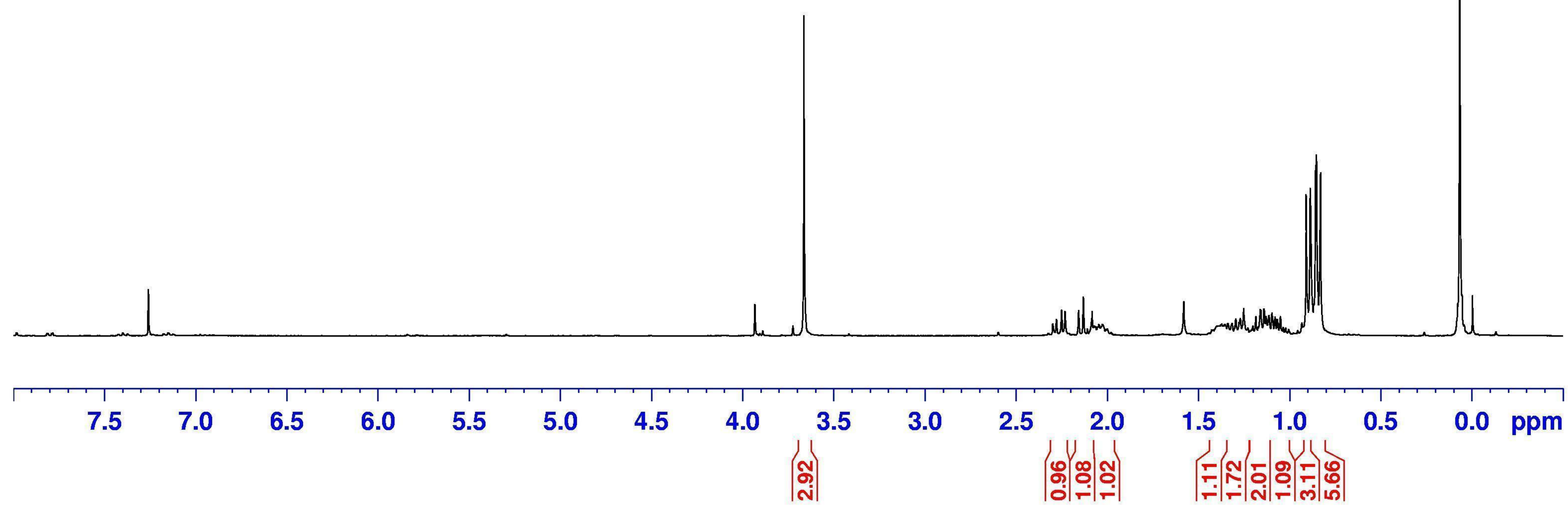

S30 

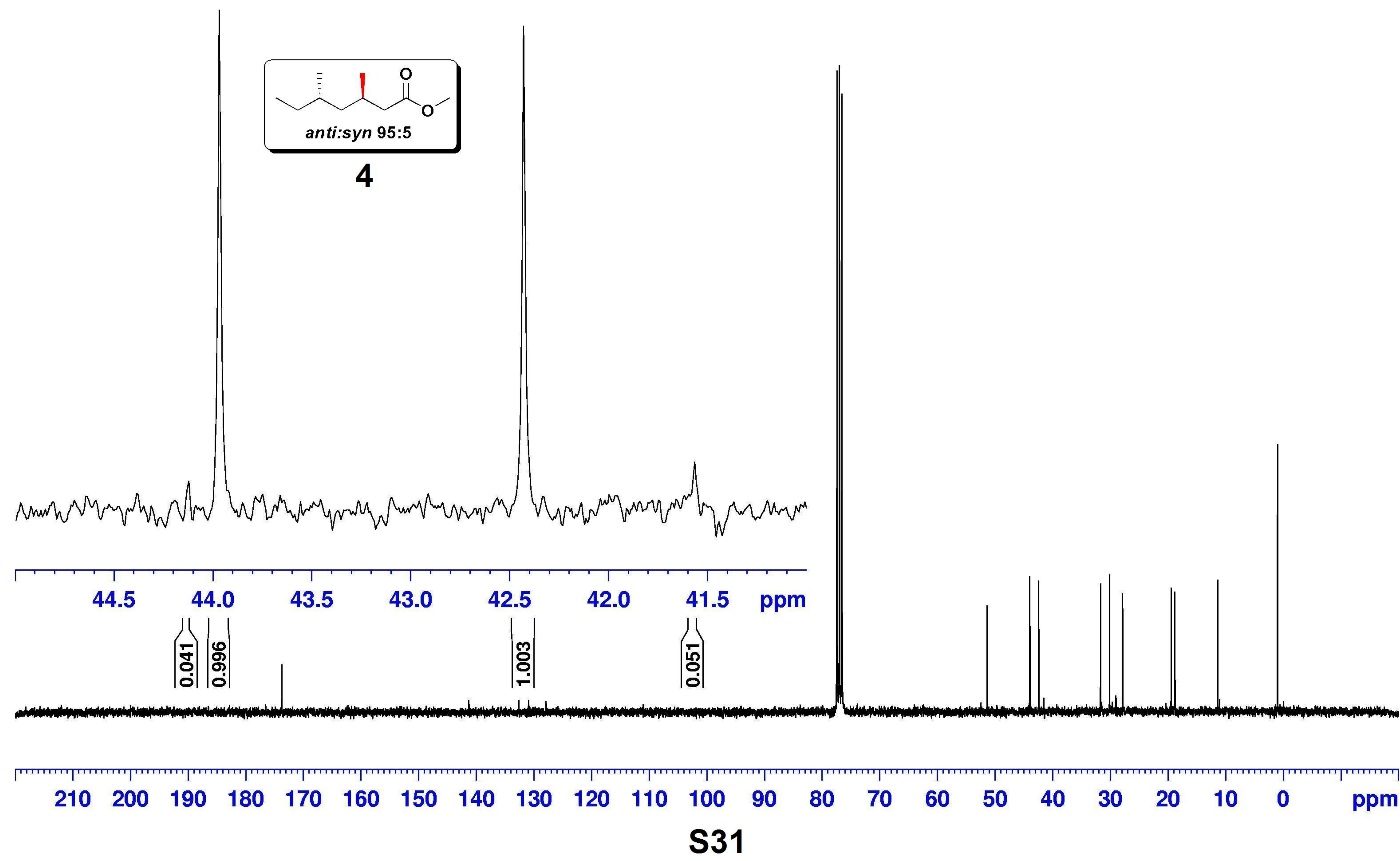


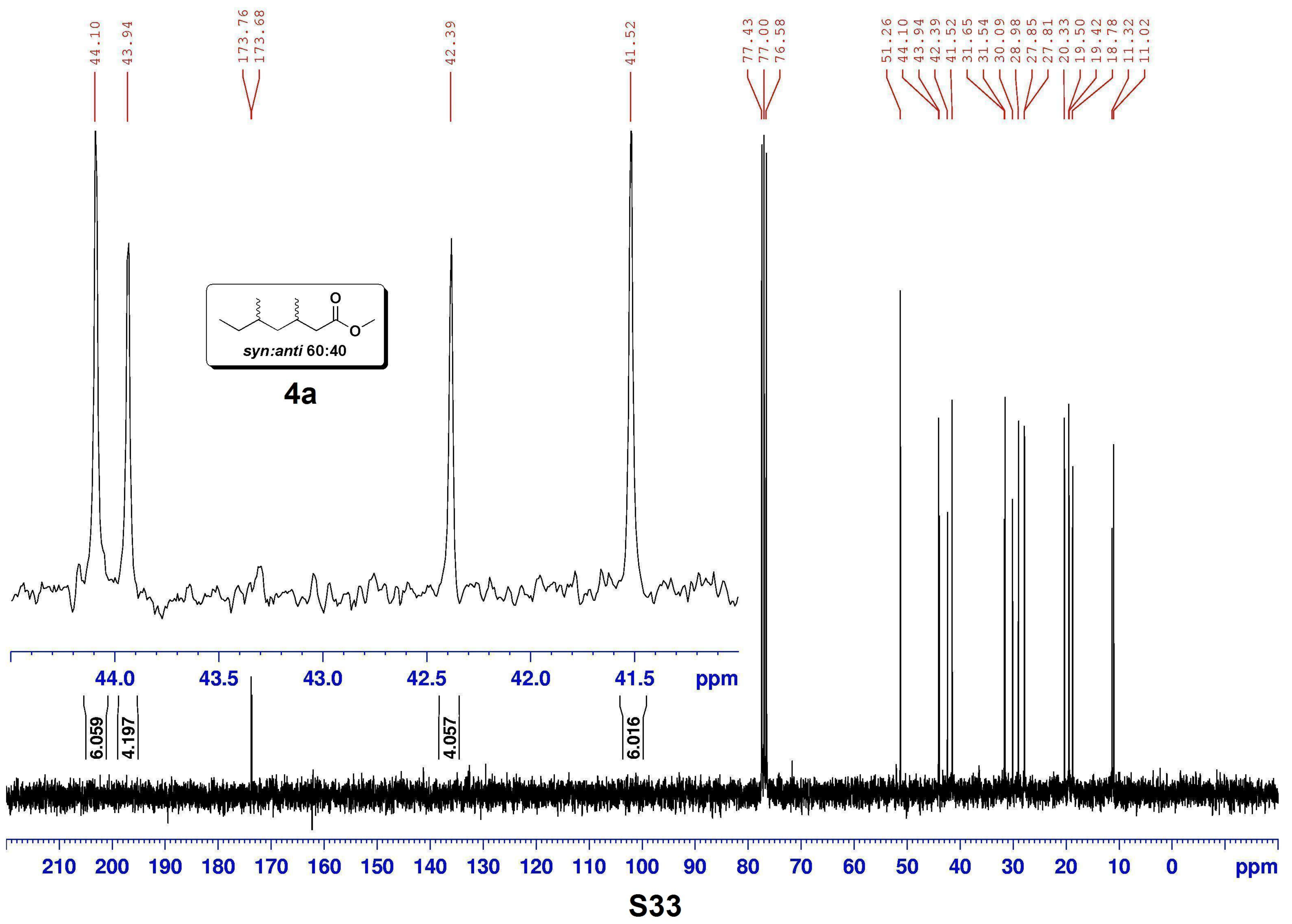




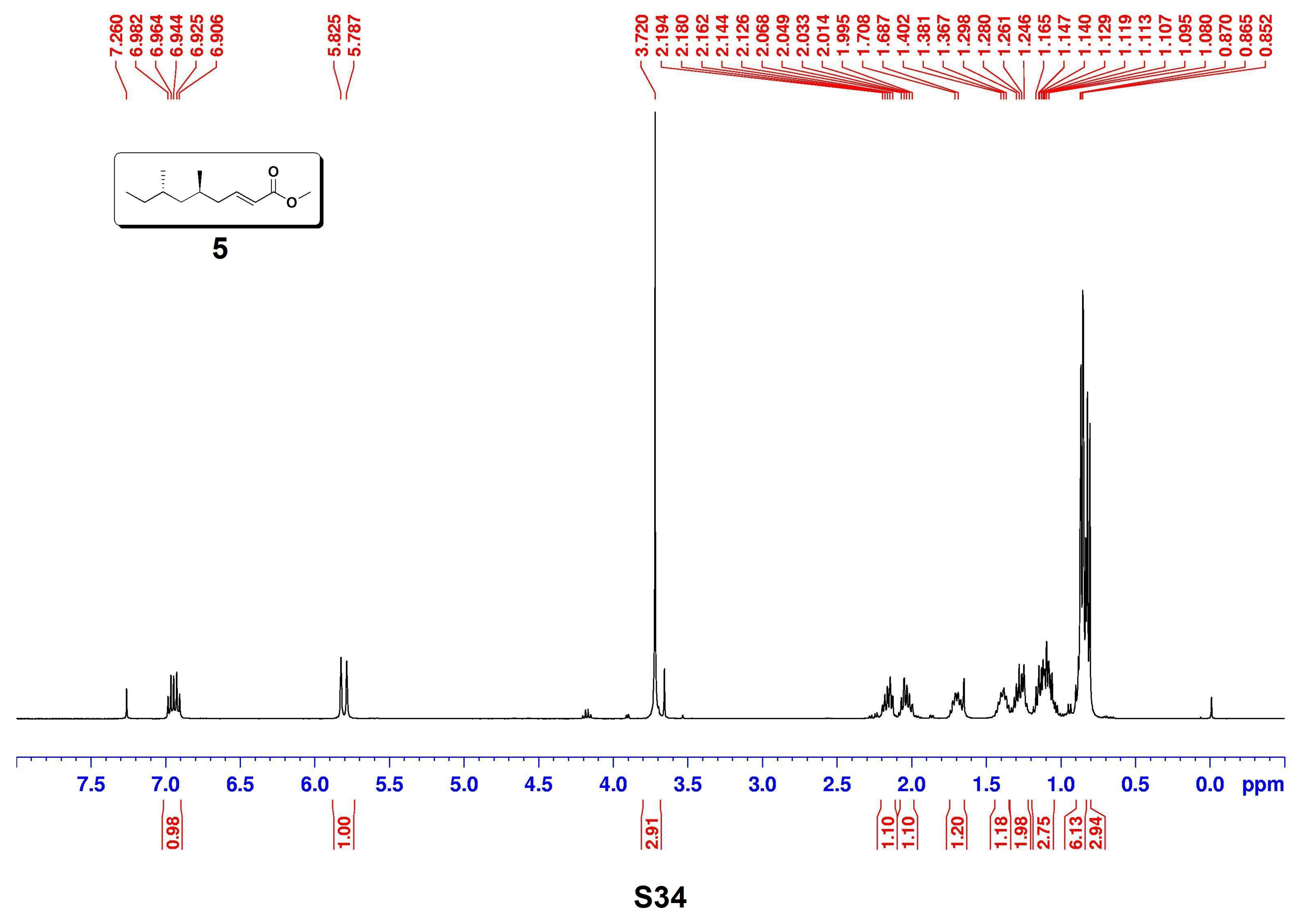




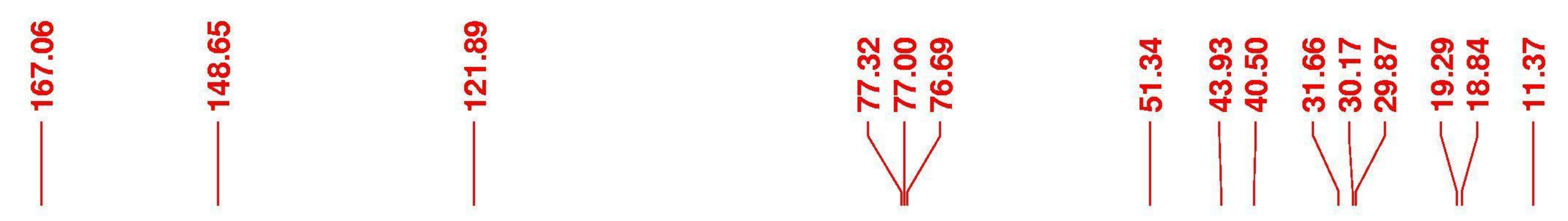

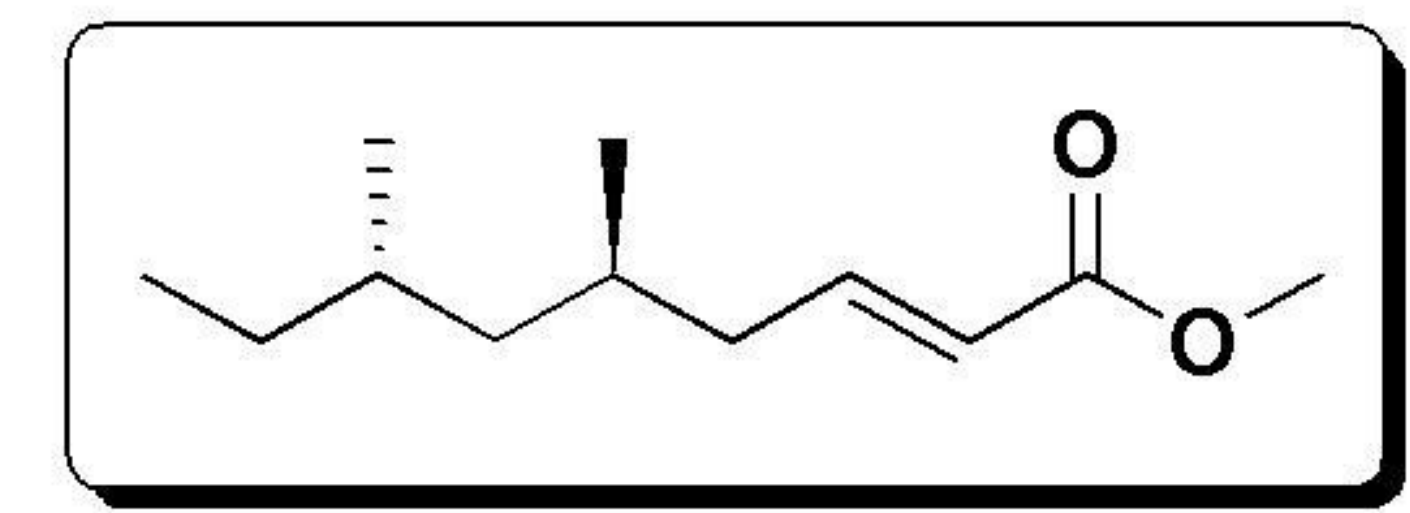

5

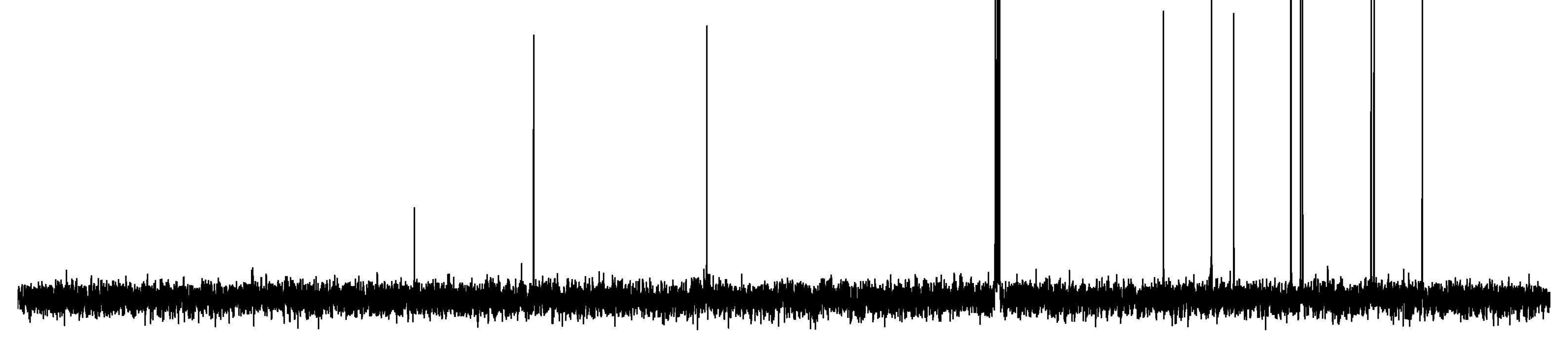

$\begin{array}{ccccccccccccccccccccccc}220 & 210 & 200 & 190 & 180 & 170 & 160 & 150 & 140 & 130 & 120 & 110 & 100 & 90 & 80 & 70 & 60 & 50 & 40 & 30 & 20 & 10 & \mathrm{ppm}\end{array}$




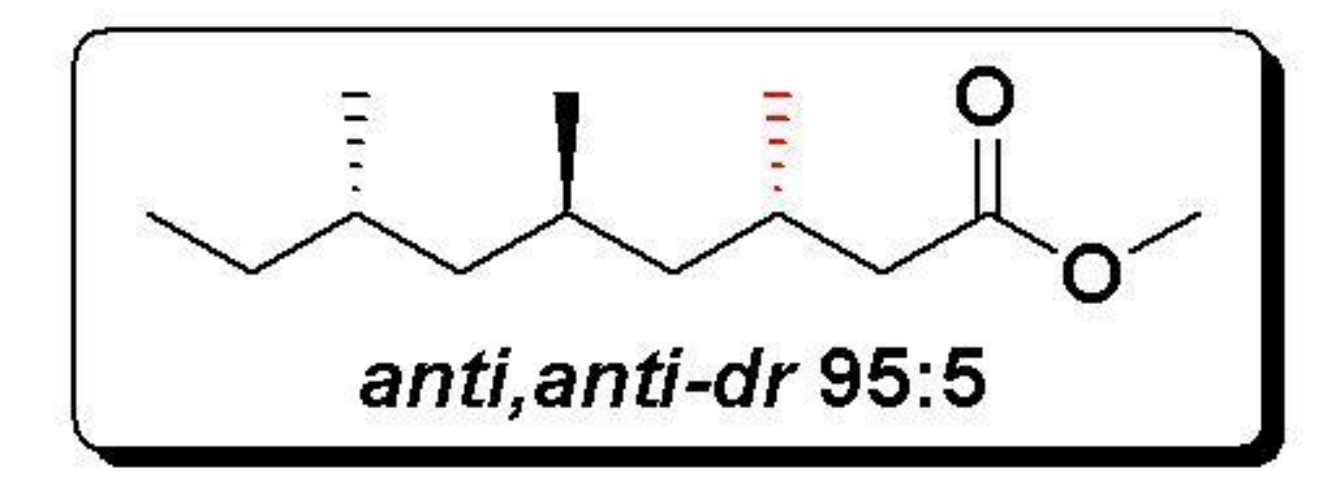

6

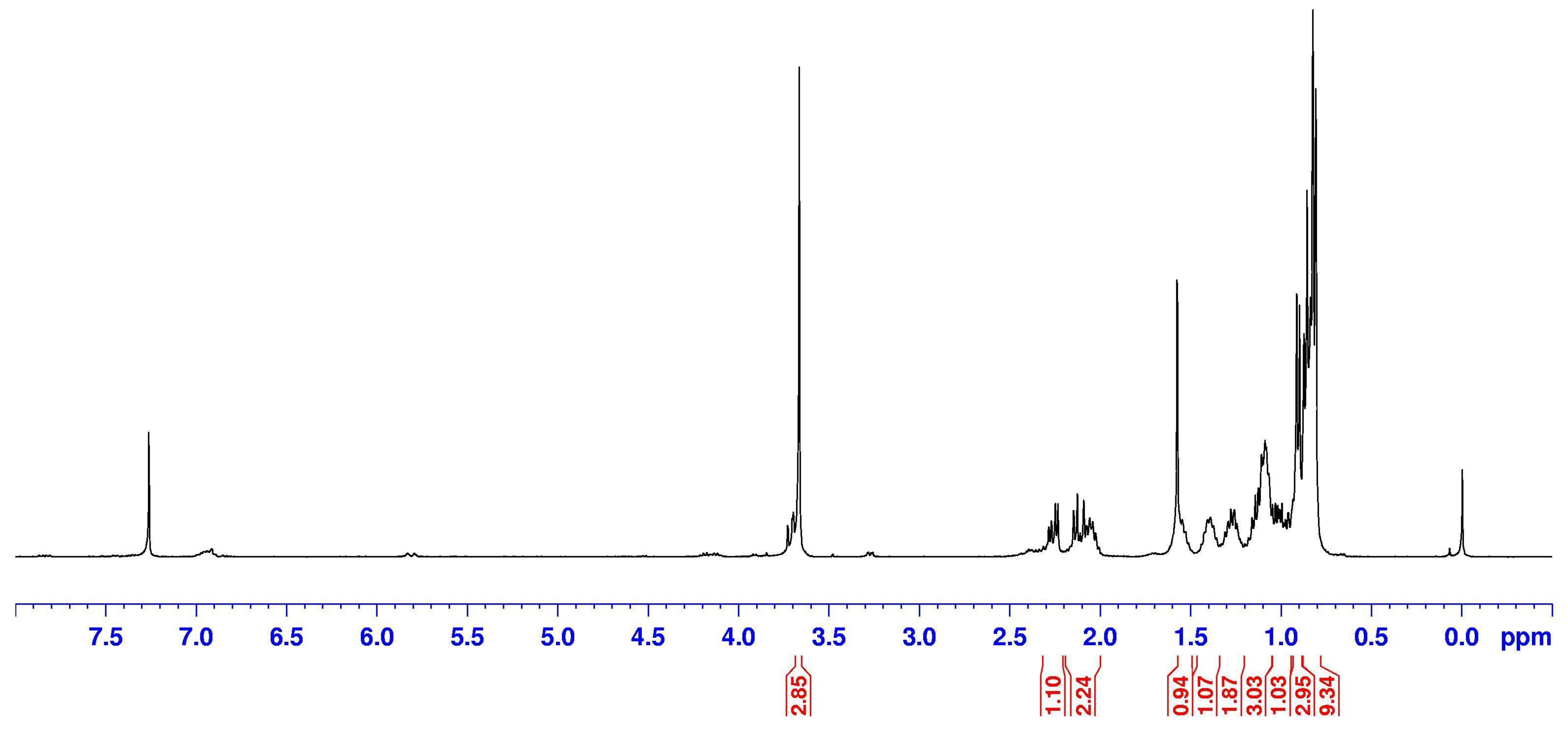




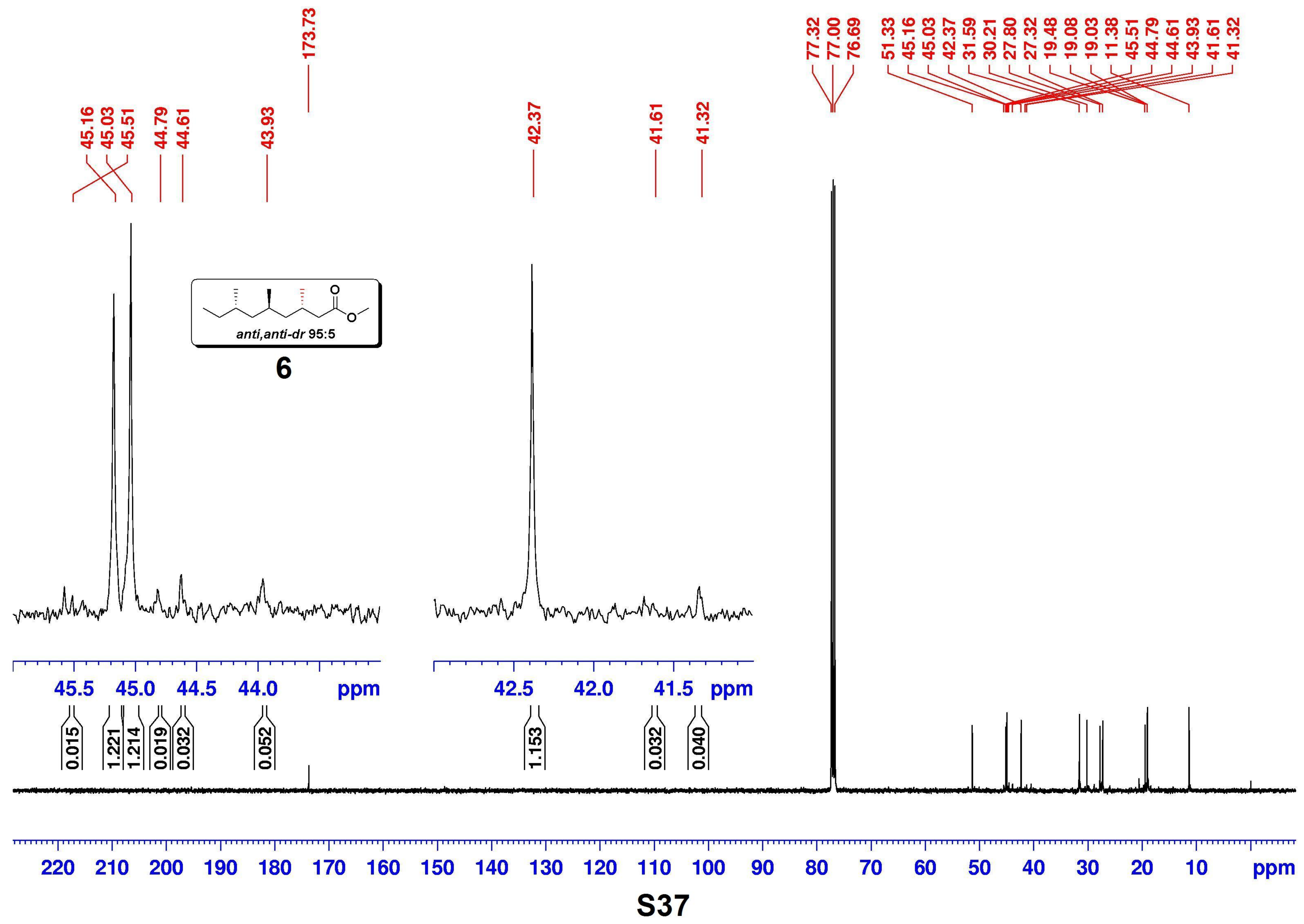




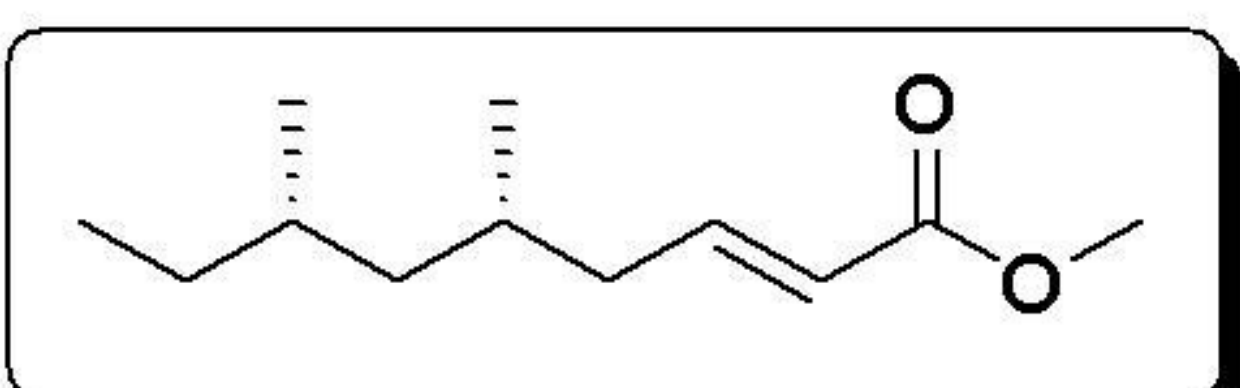

7
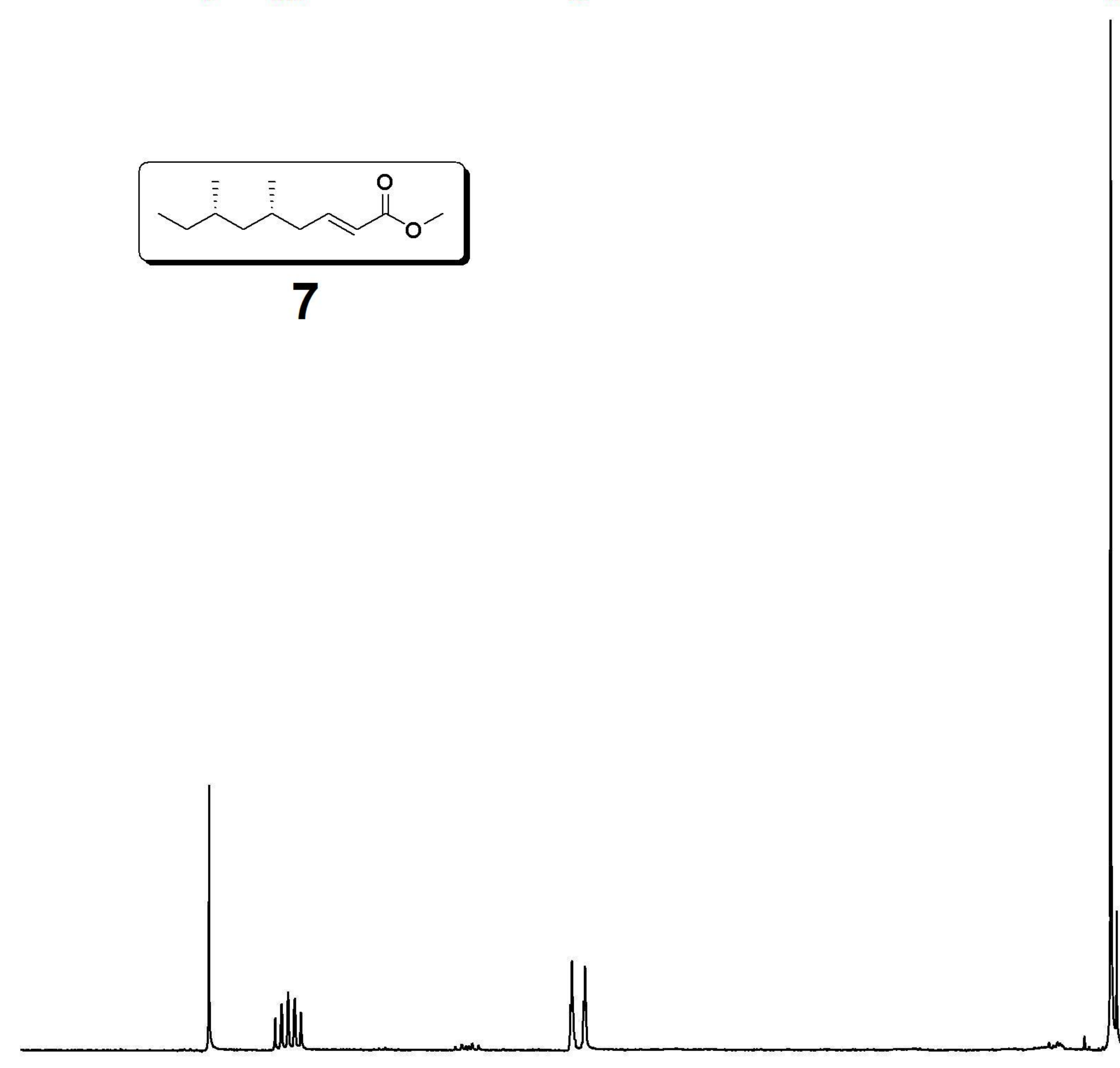

Tाiा Tiाก -
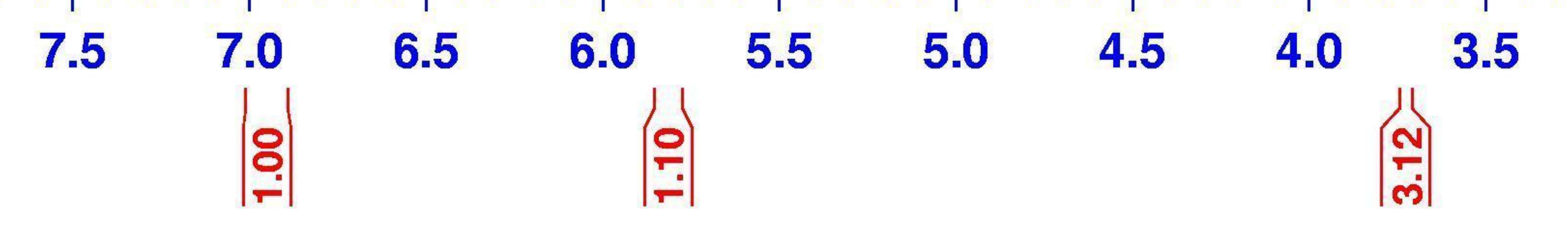

3.0

2.5

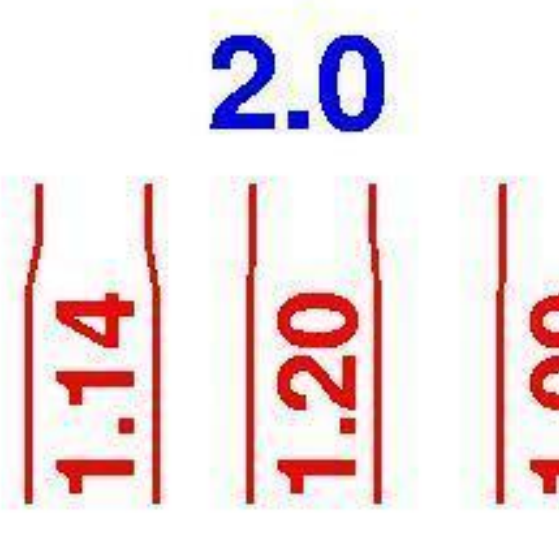

1.51 .0

S38 


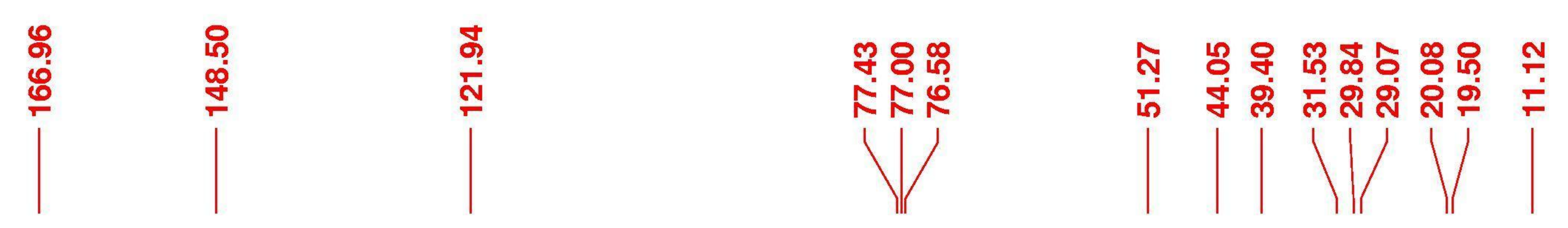
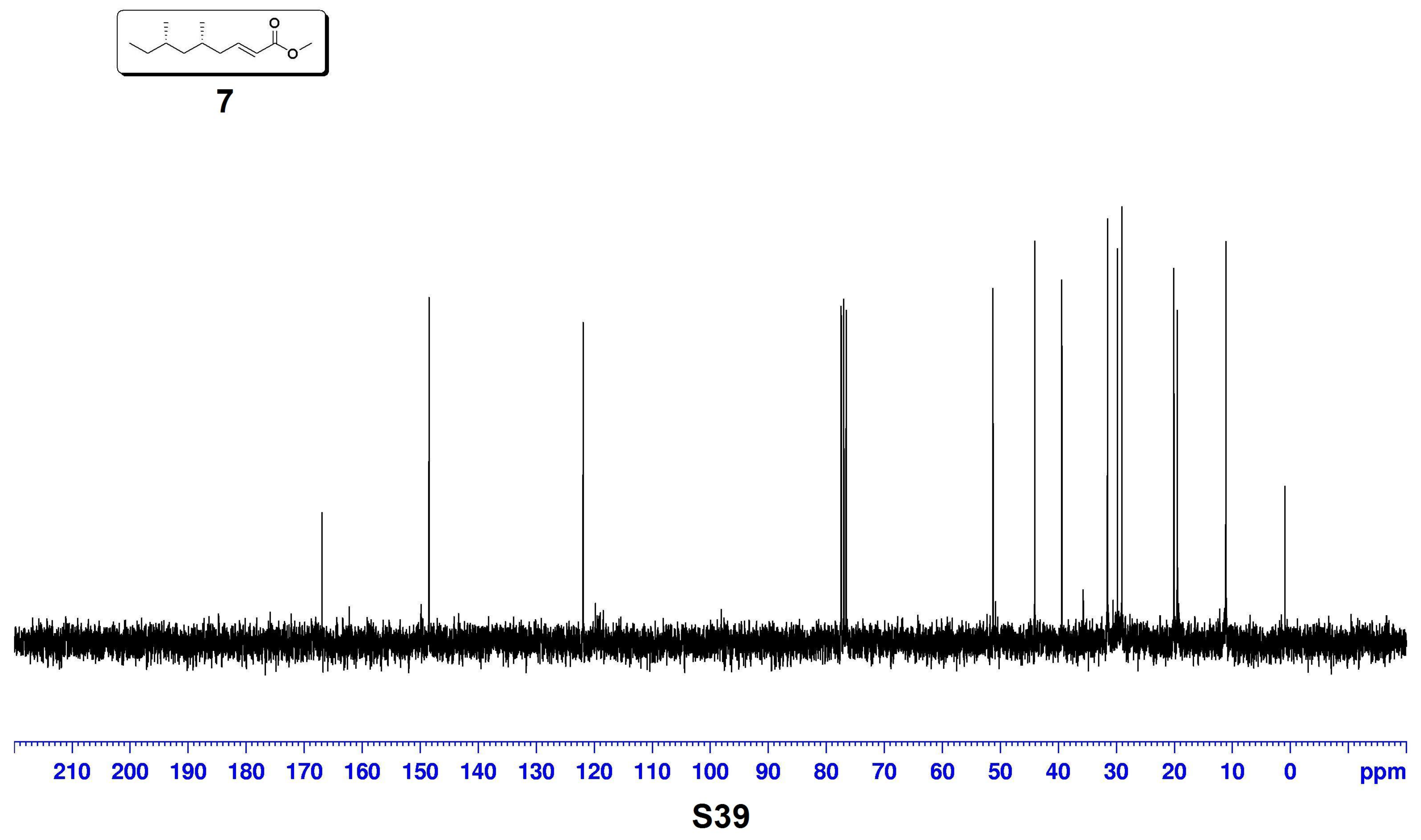


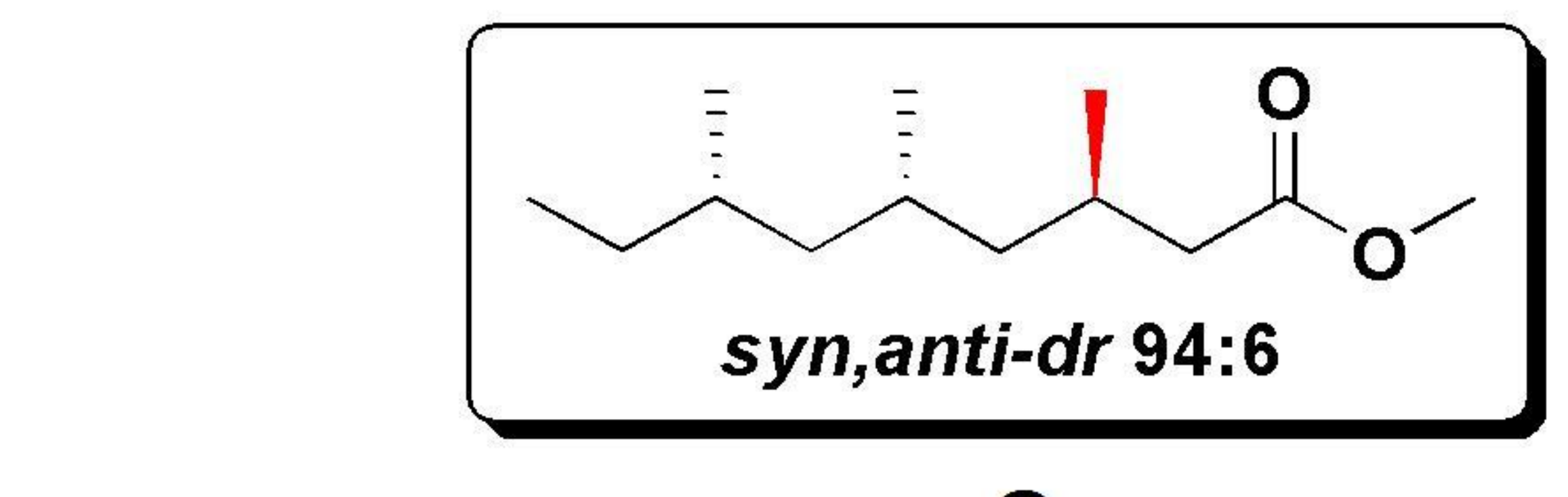

8
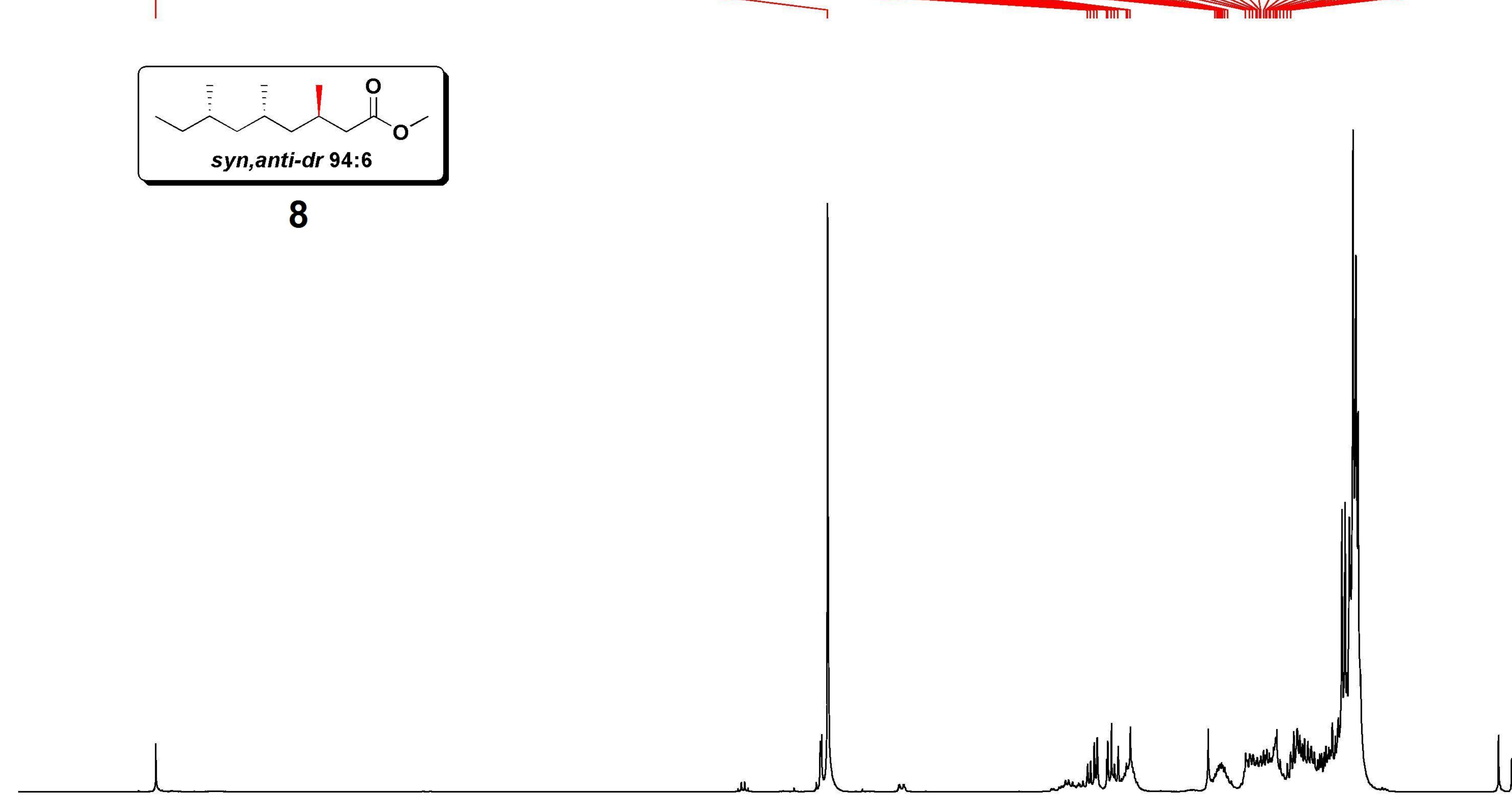

7.5

7.0

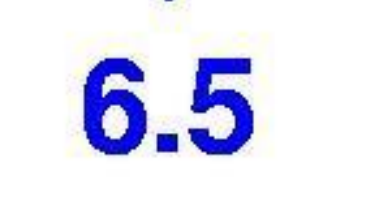

6.0

5.5

5.0

4.5

4.0

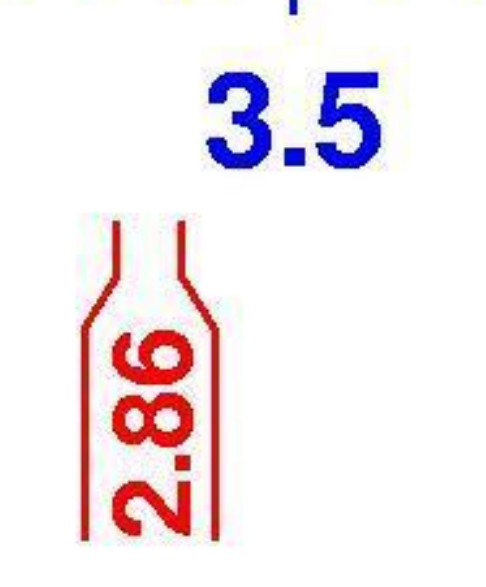

3.0

2.5

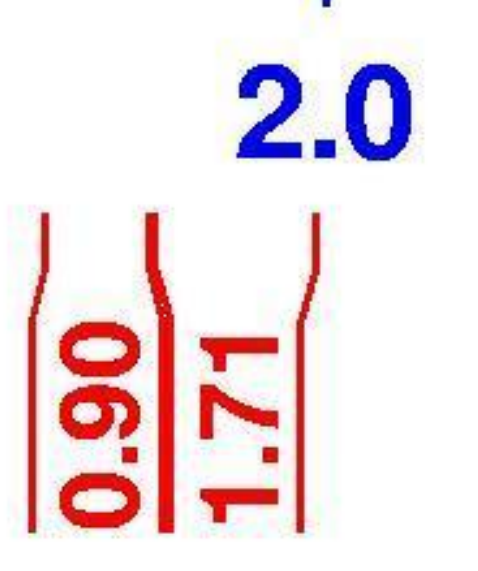

|잉.

$0.5 \quad 0.0 \mathrm{ppm}$

S40 


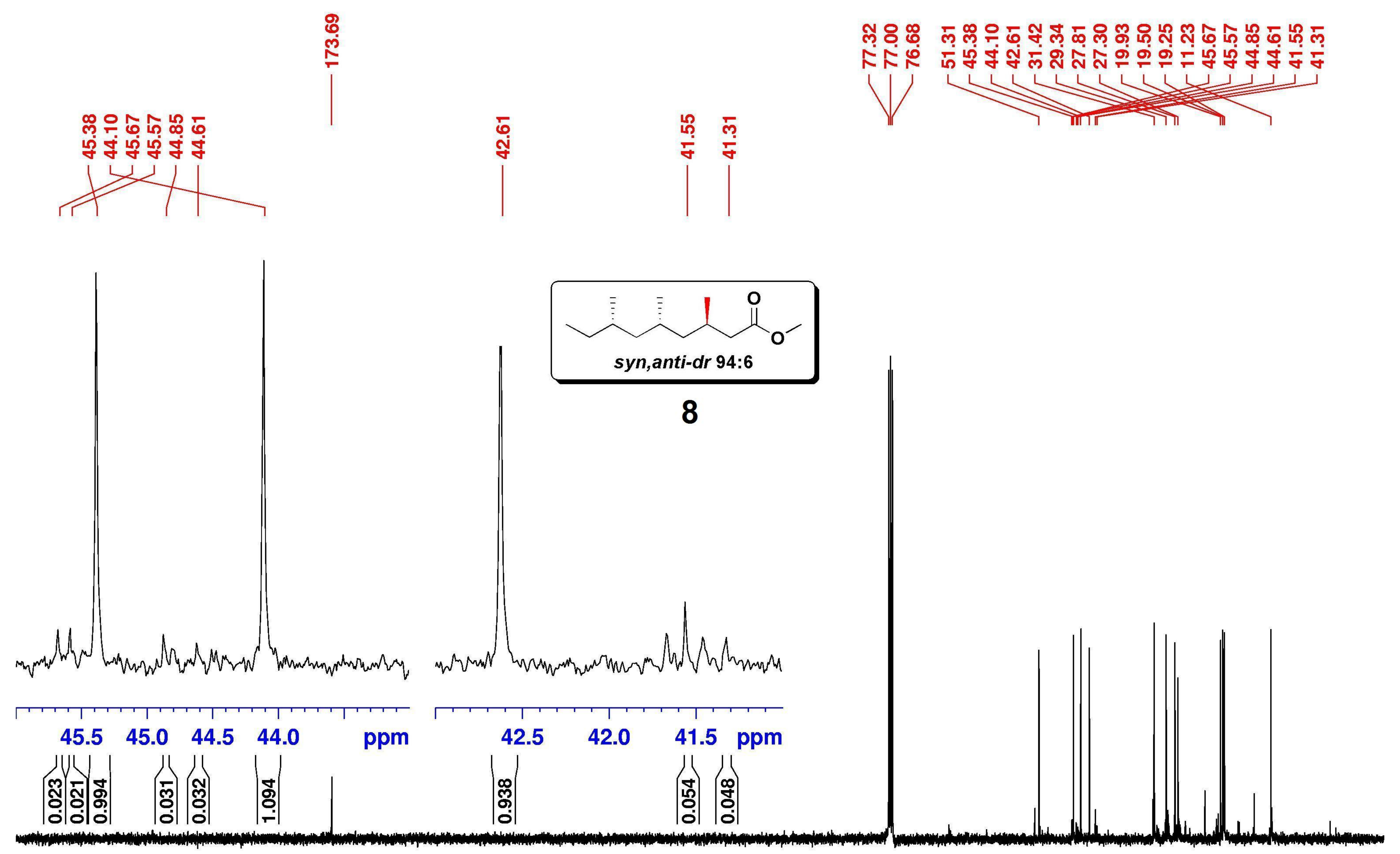

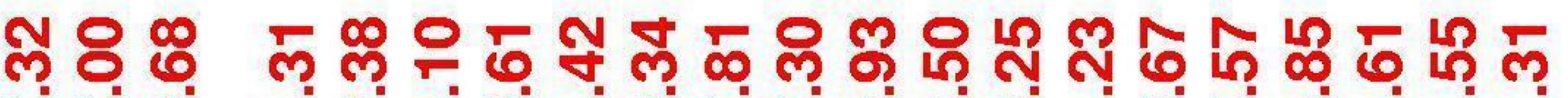

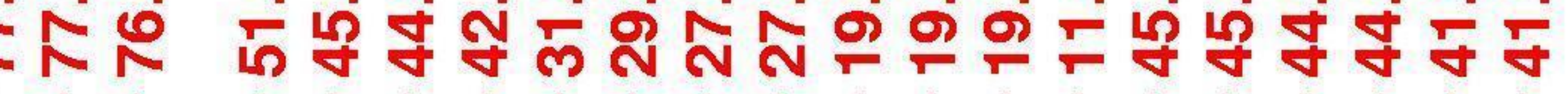

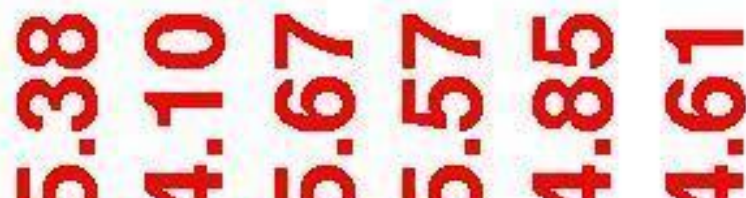

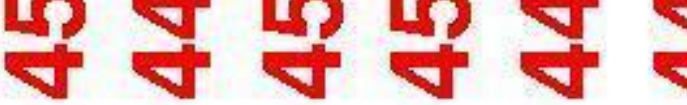

8

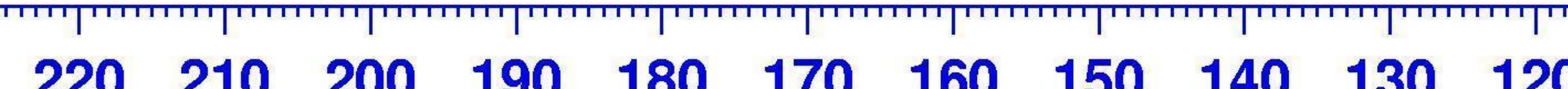

110

\section{S41}




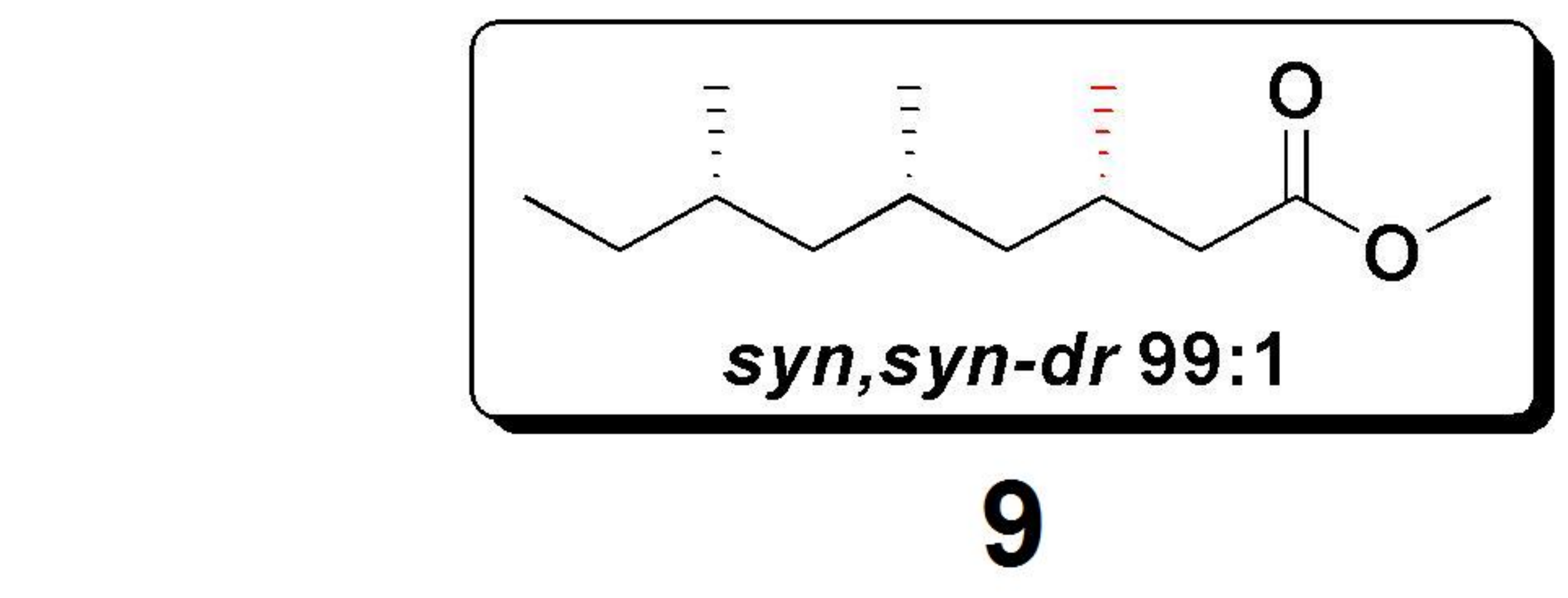

9

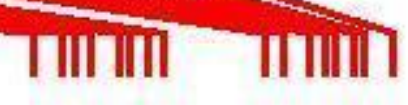

IIIII)
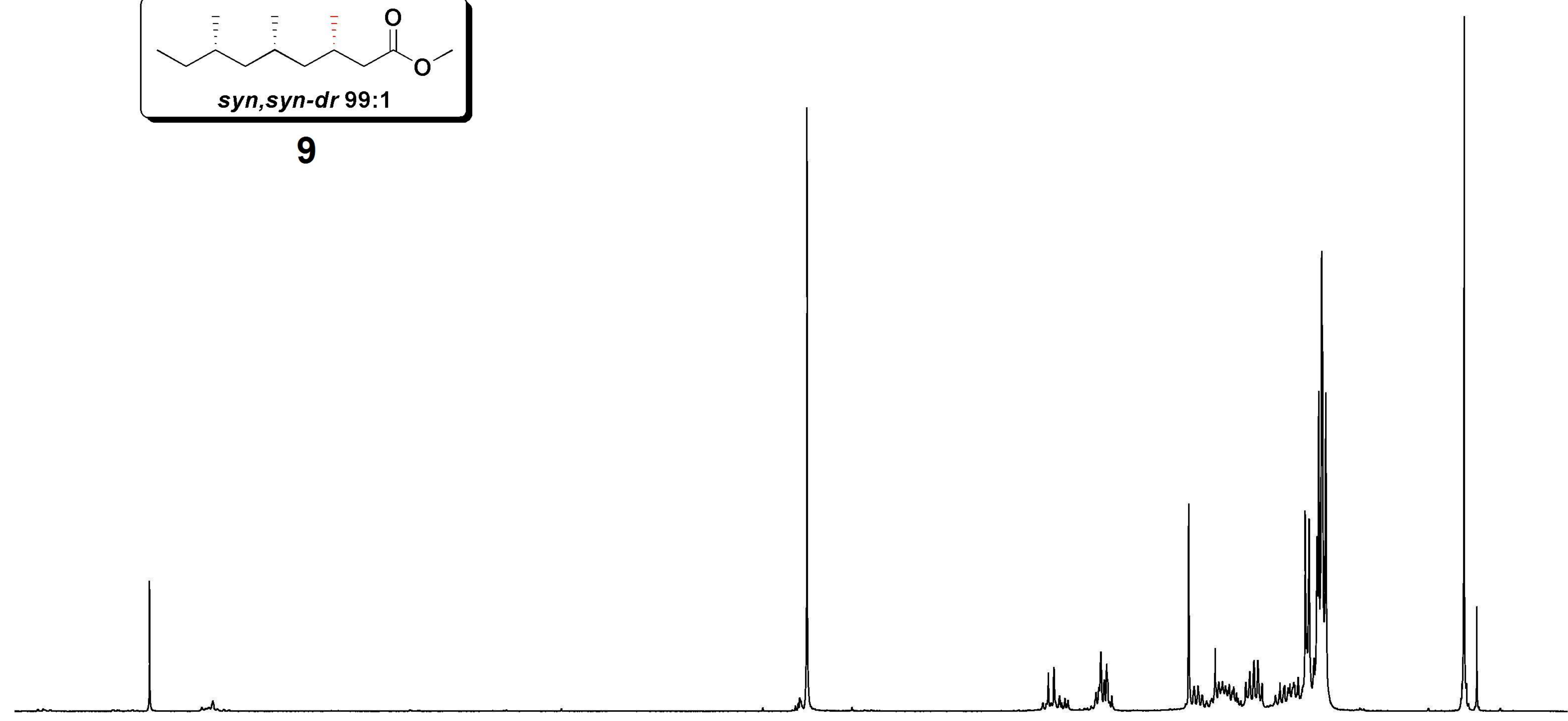

$\begin{array}{llllllllll}7.5 & 7.0 & 6.5 & 6.0 & 5.5 & 5.0 & 4.5 & 4.0 \\ & & & & & & & \\ \text { 点 } \\ \text { N }\end{array}$

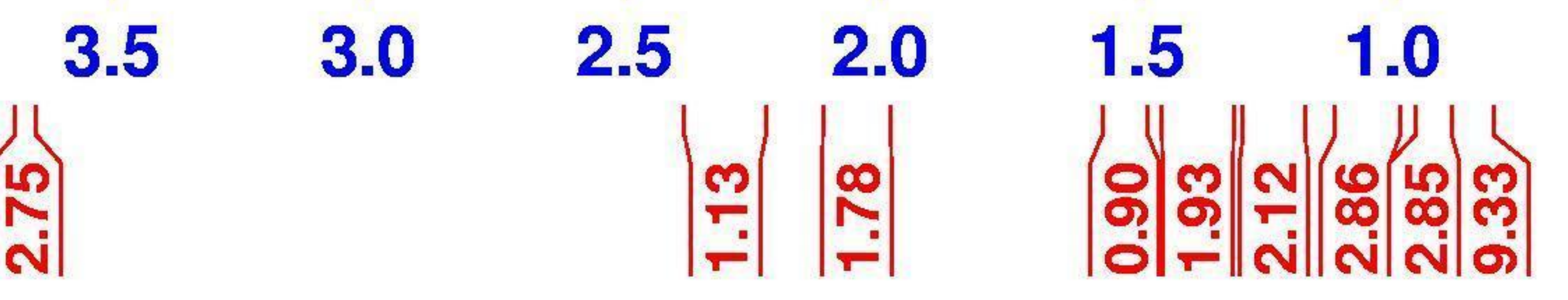

S42 

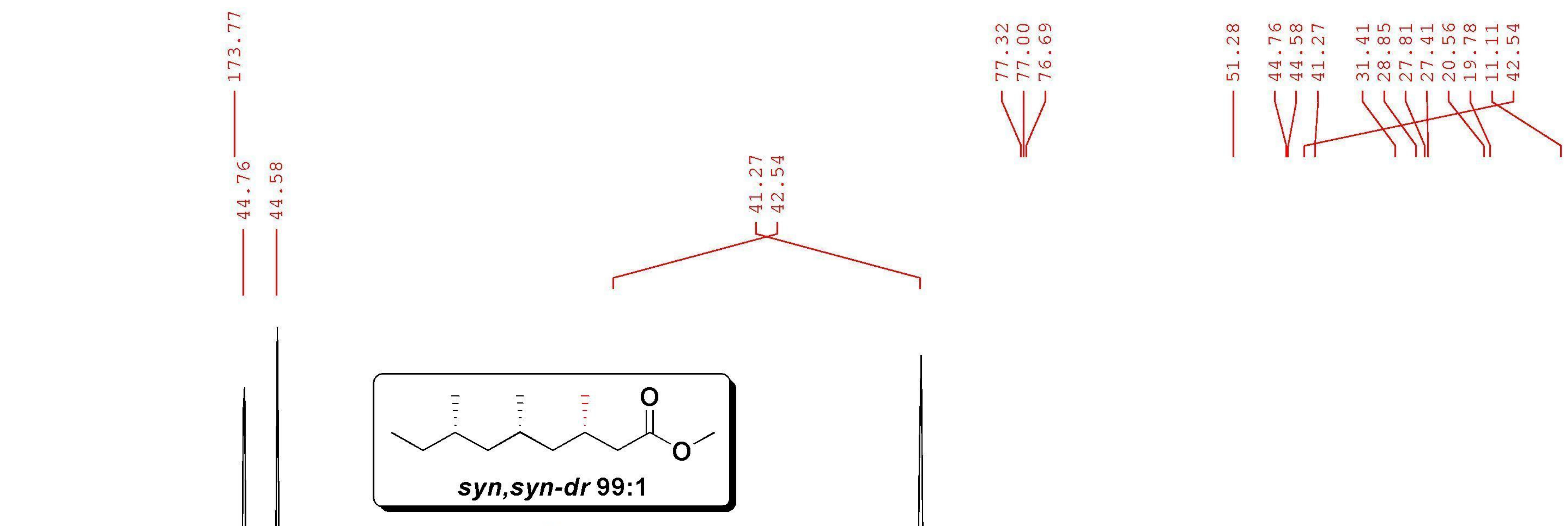

9

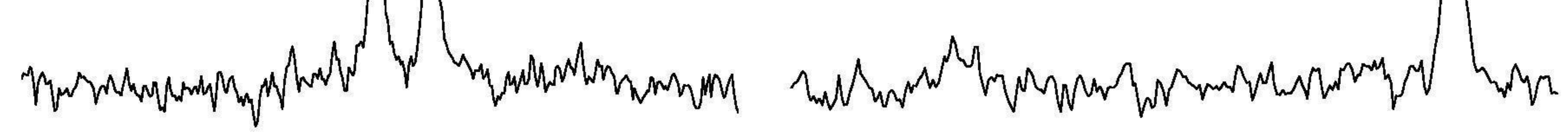
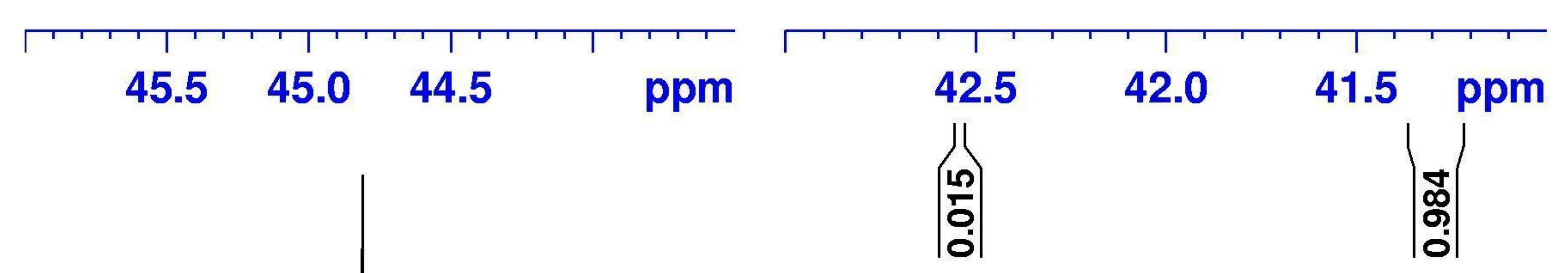


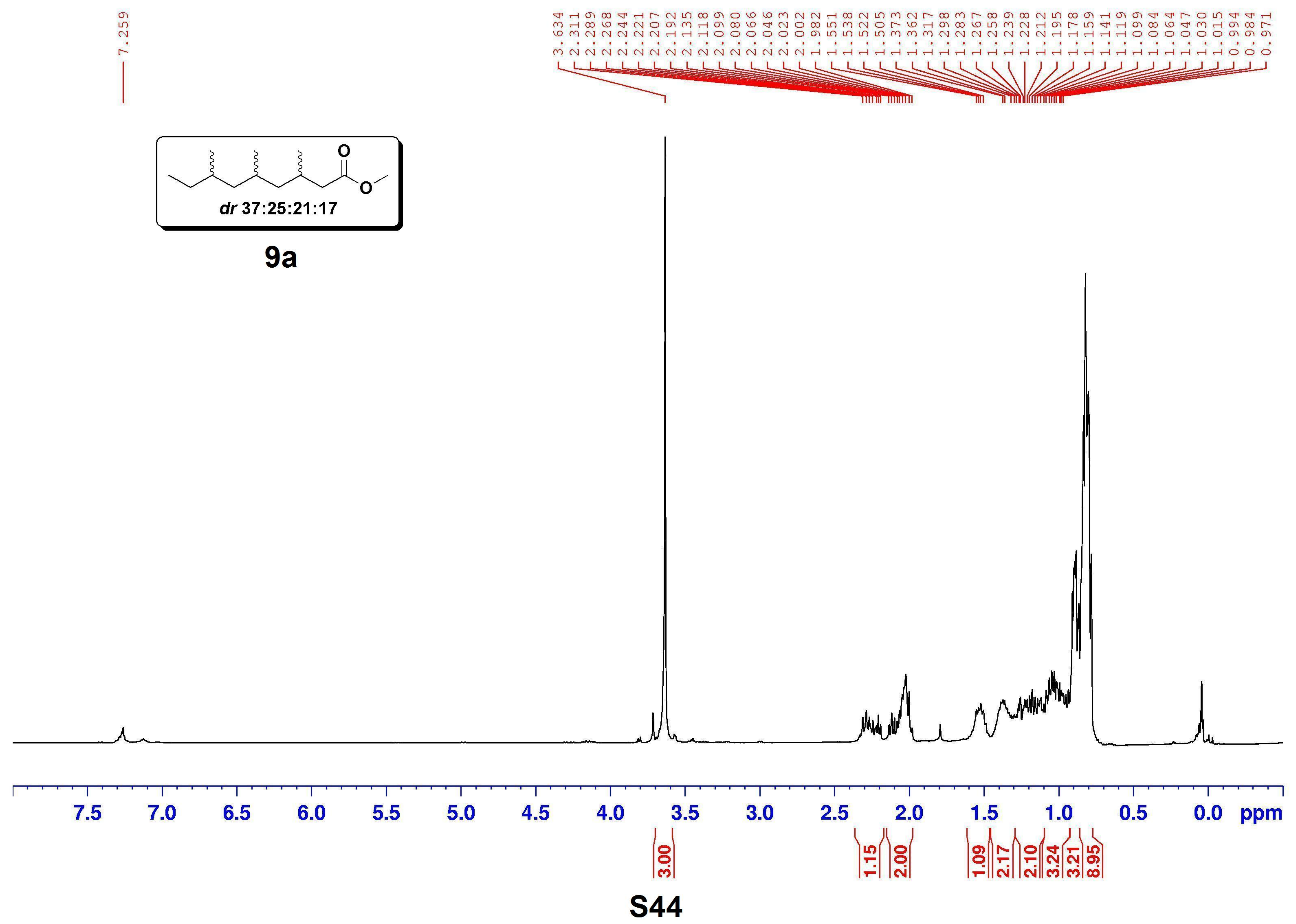




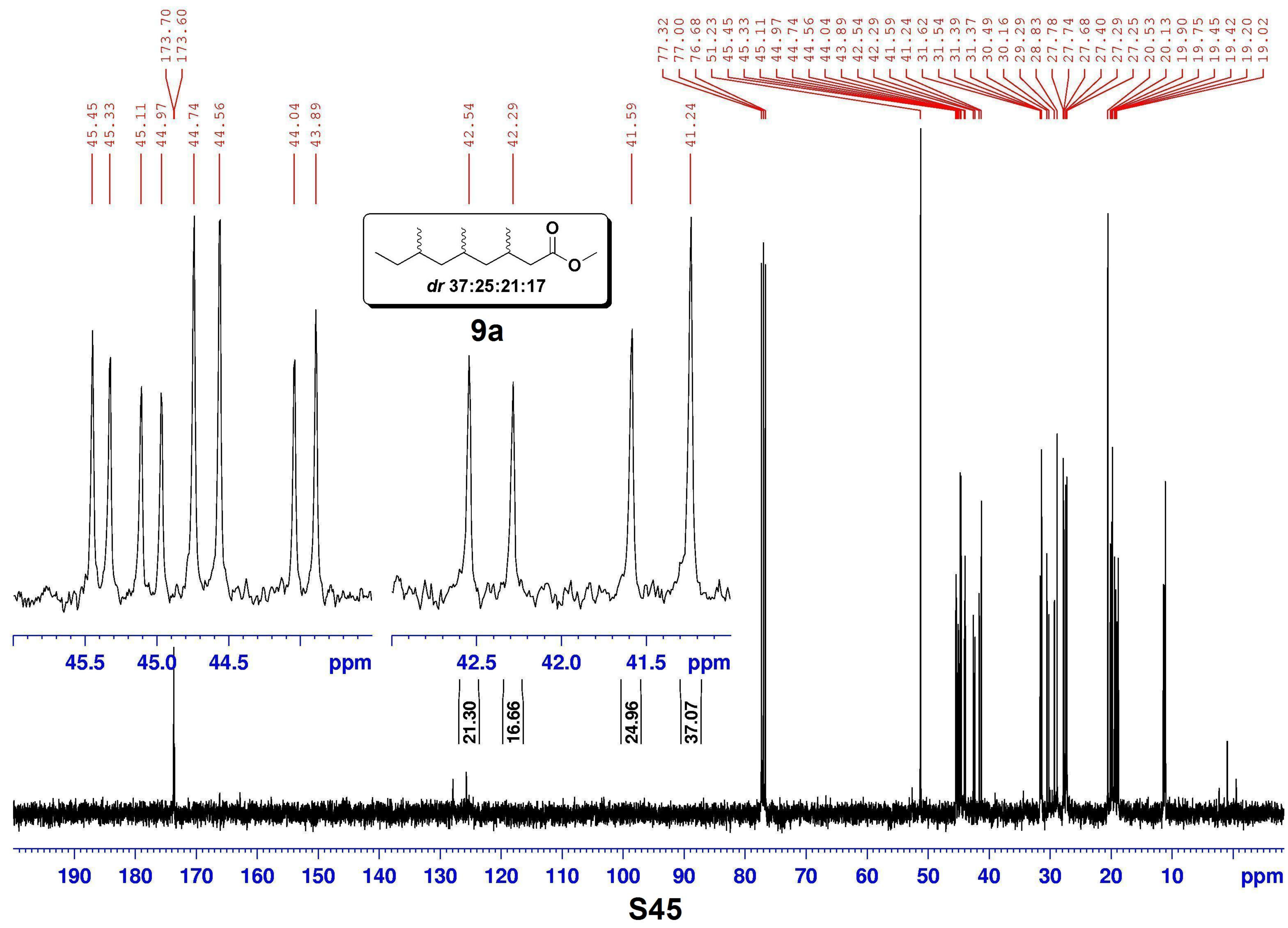




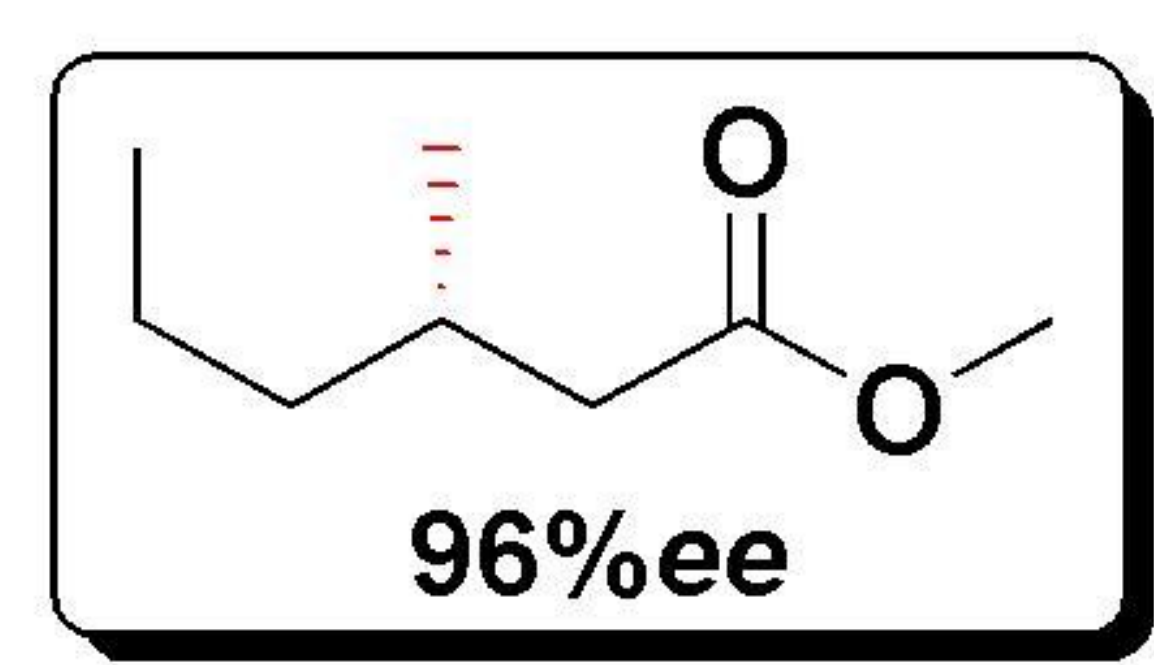

Tiाi IIIIIIII

12
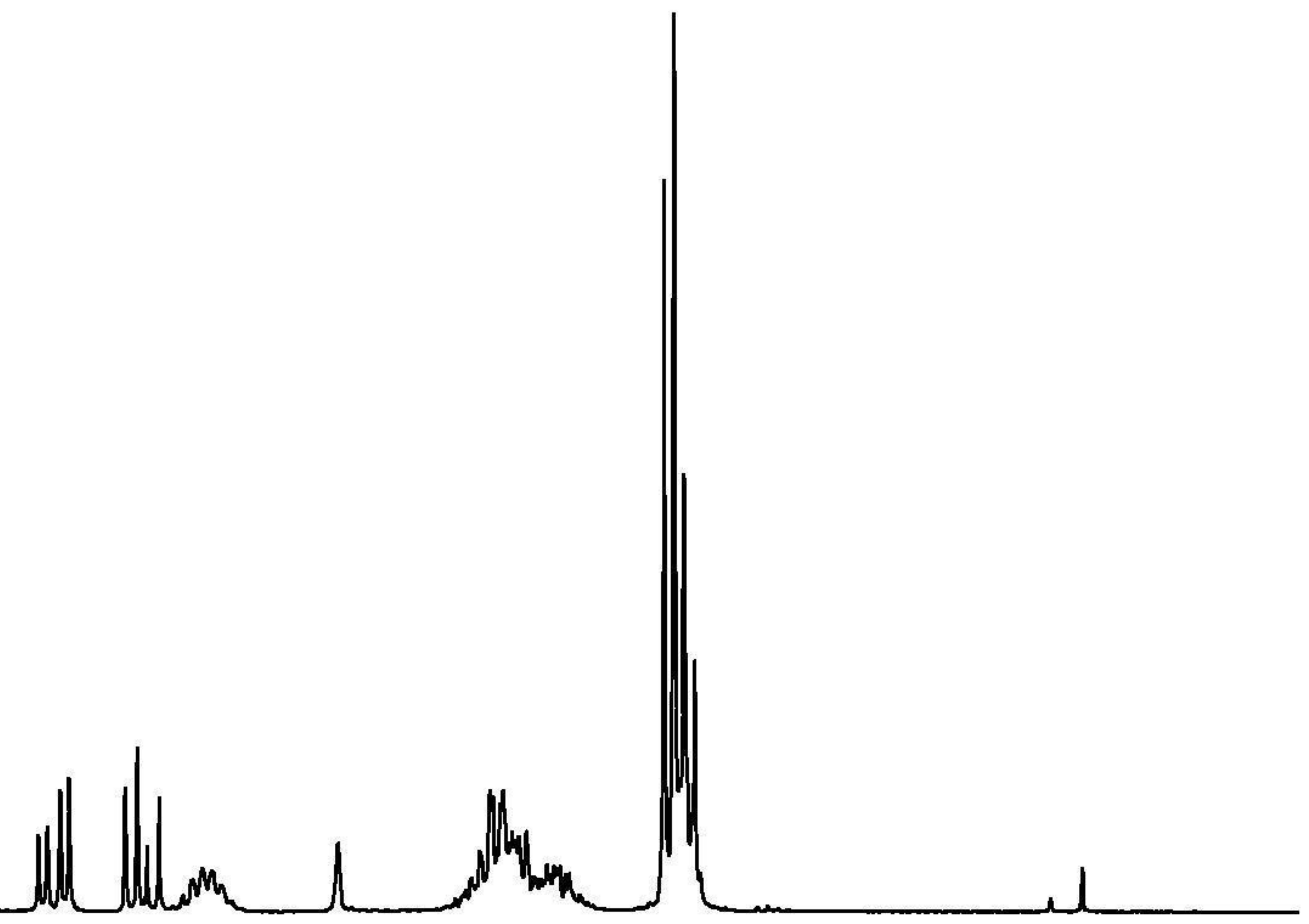


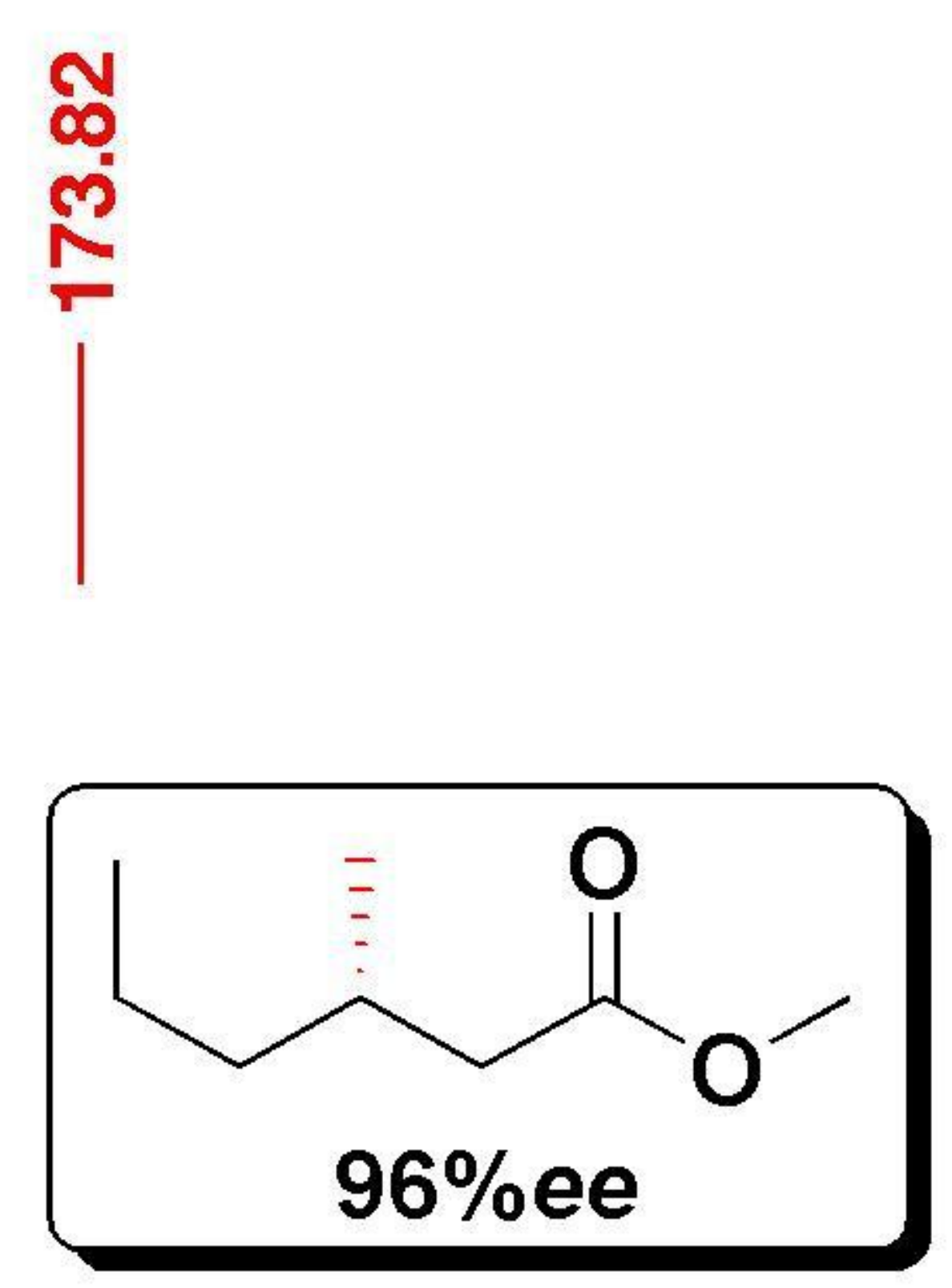

12
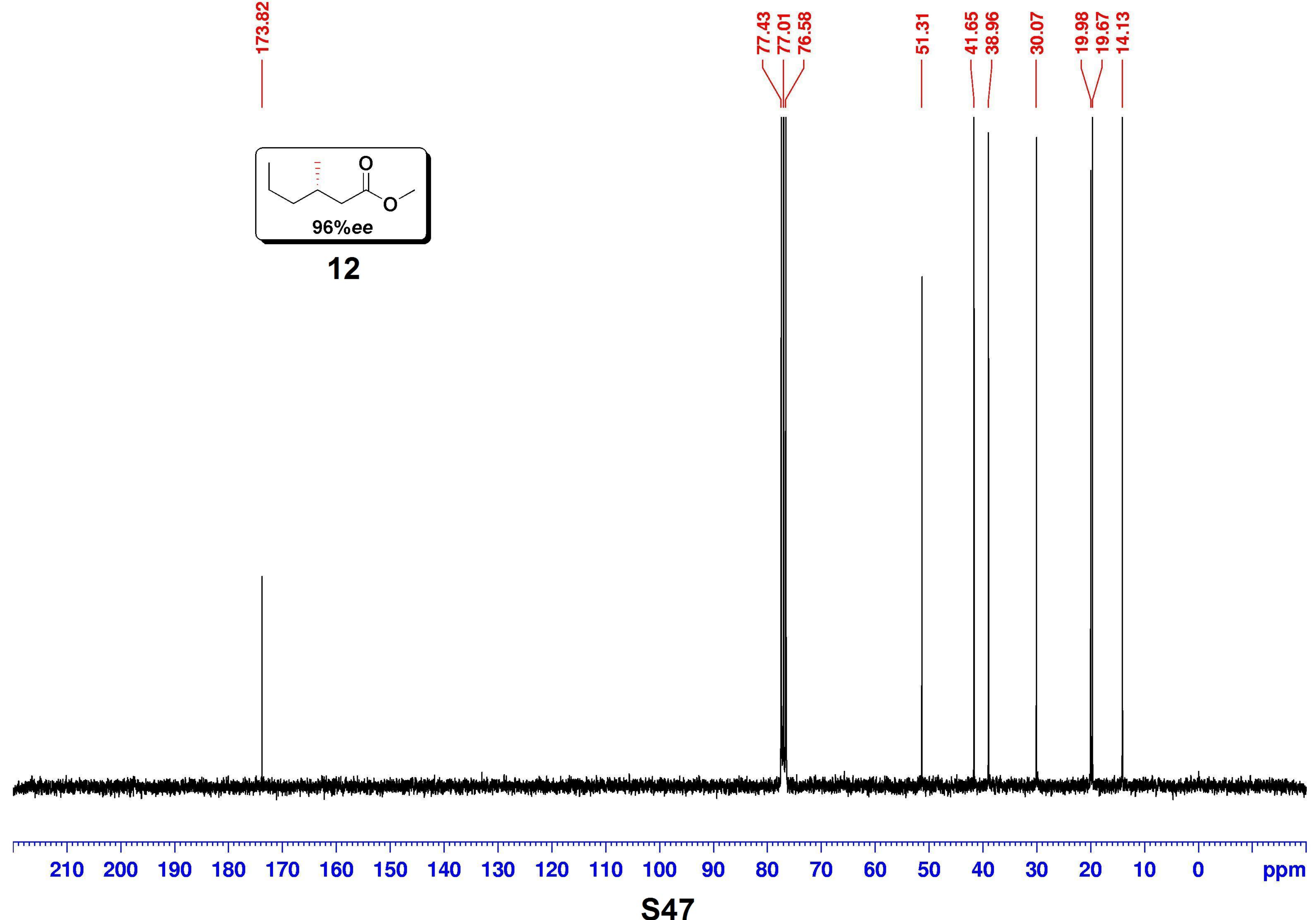


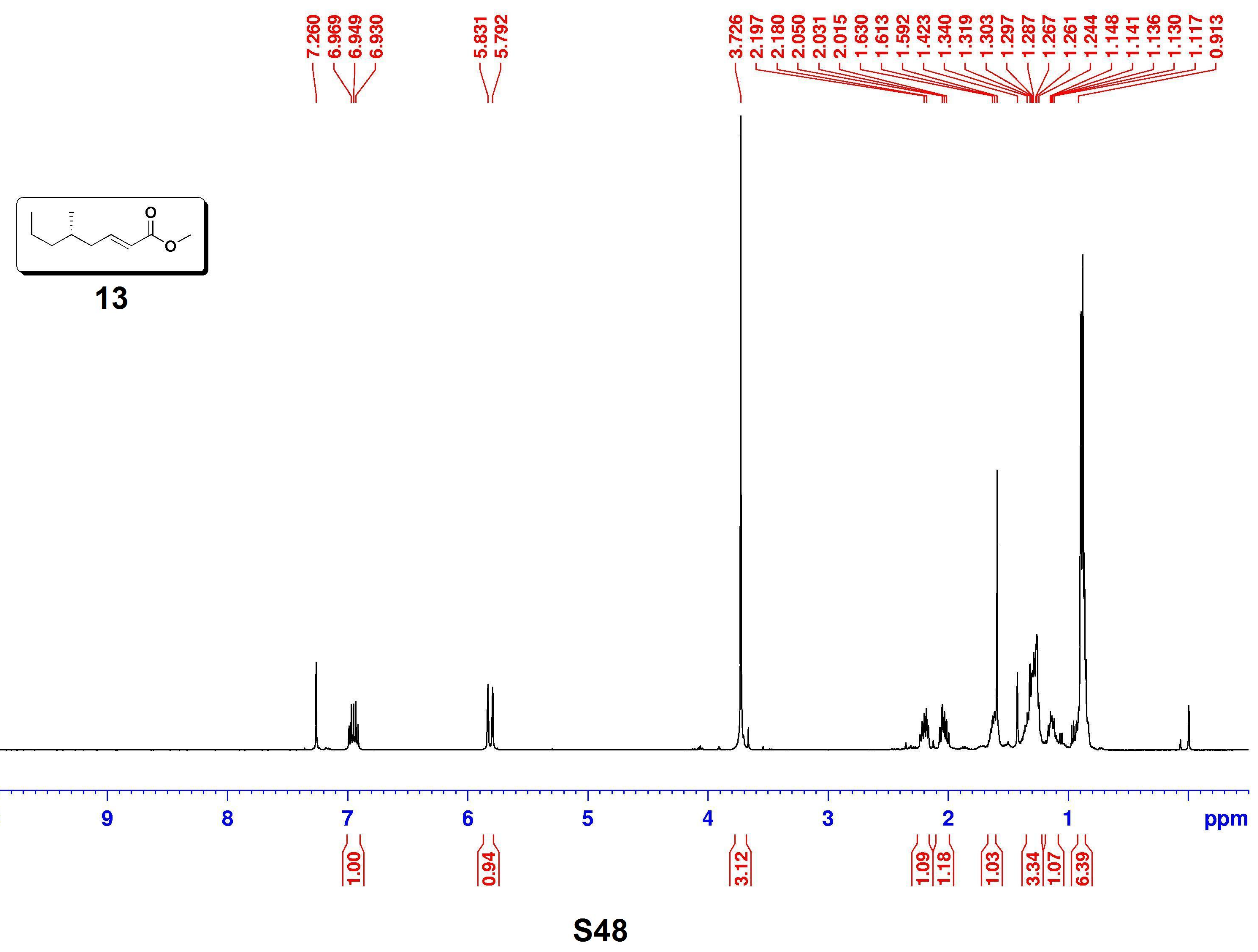




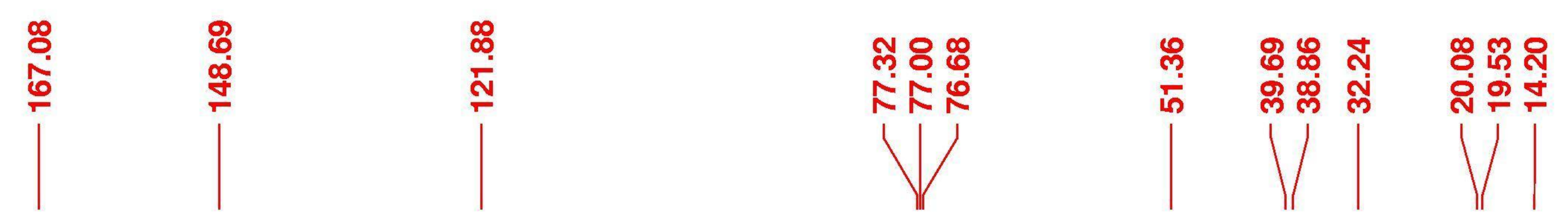

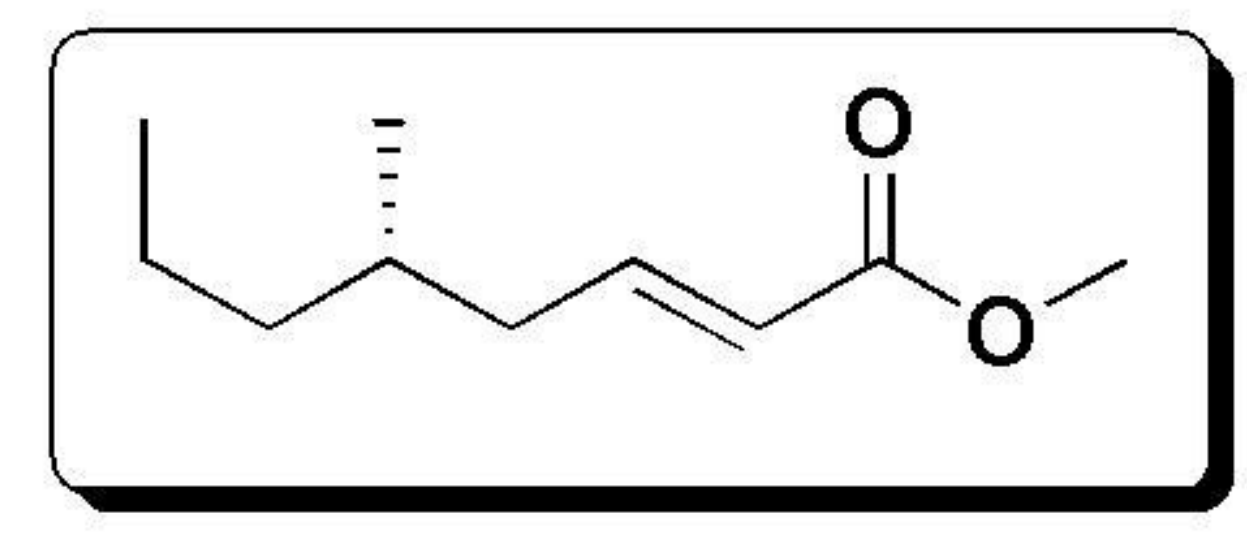

13

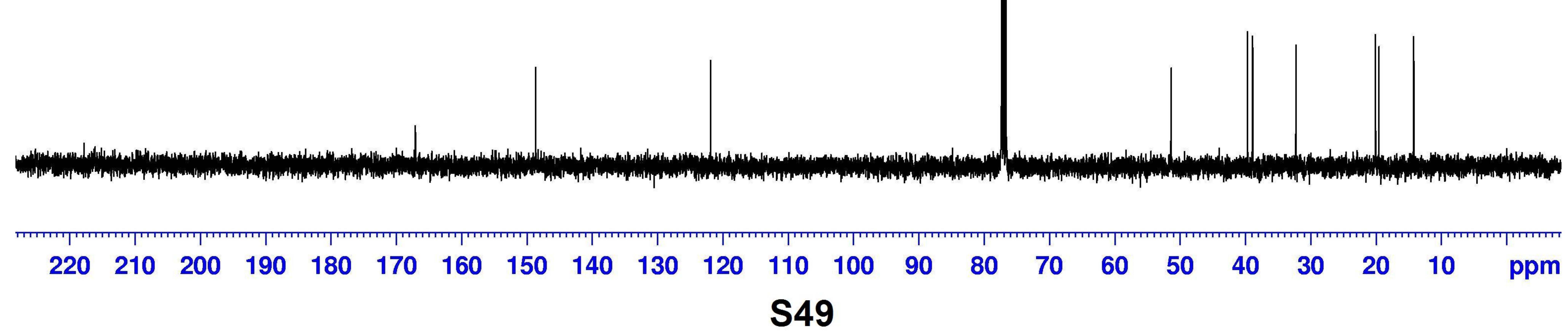



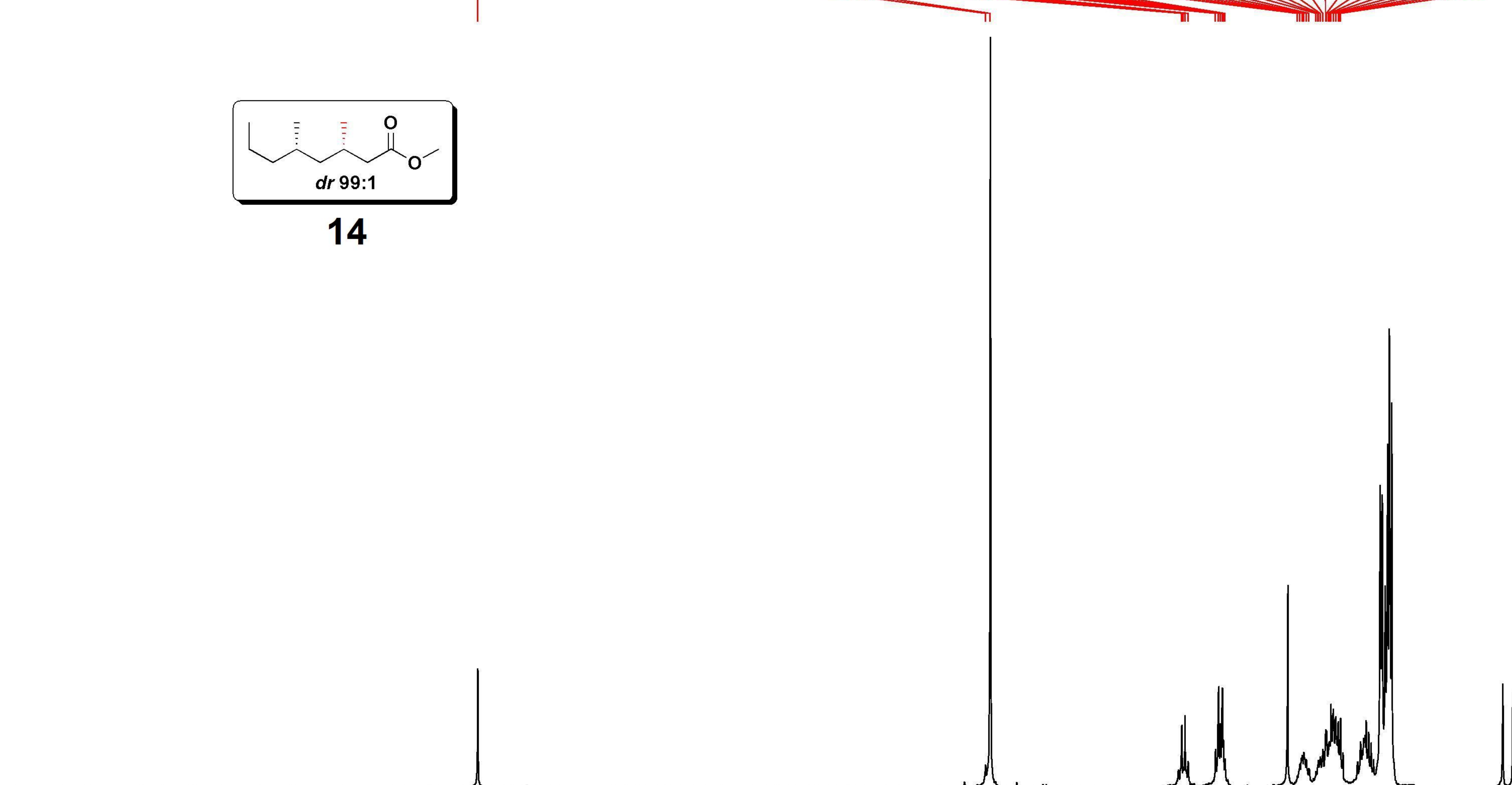

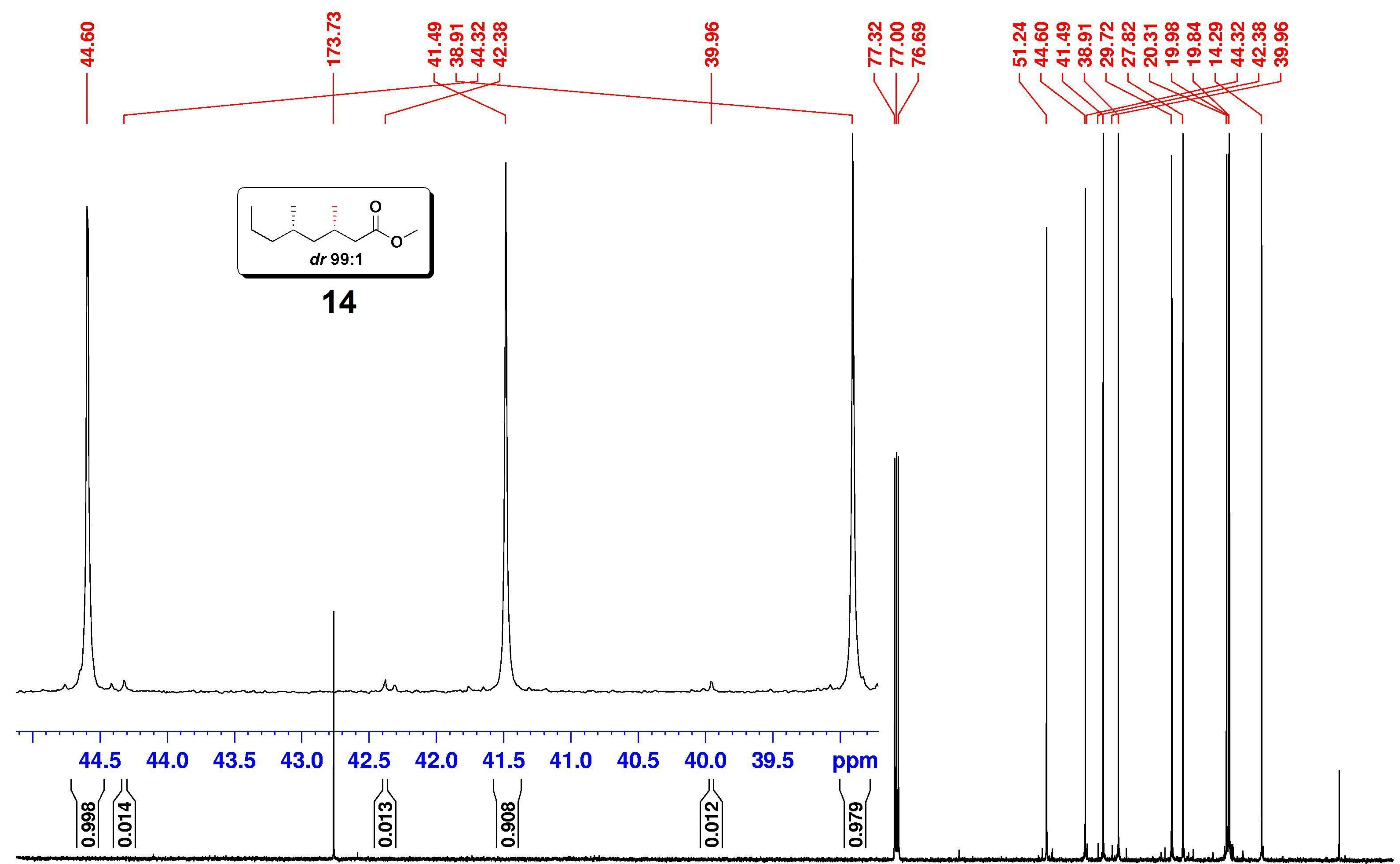


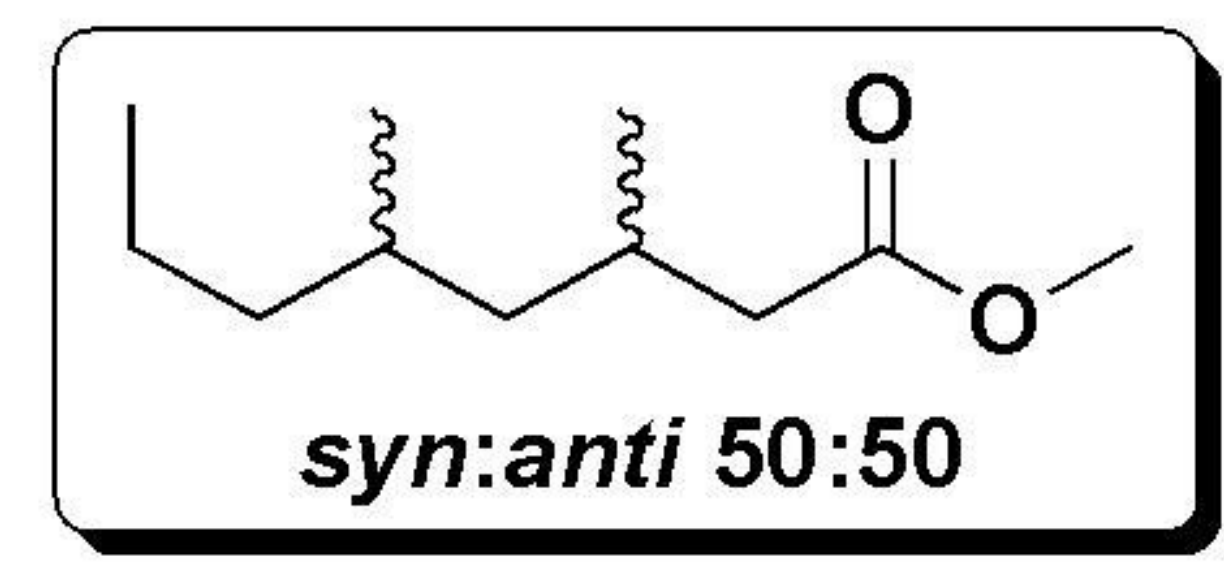

$14 a$
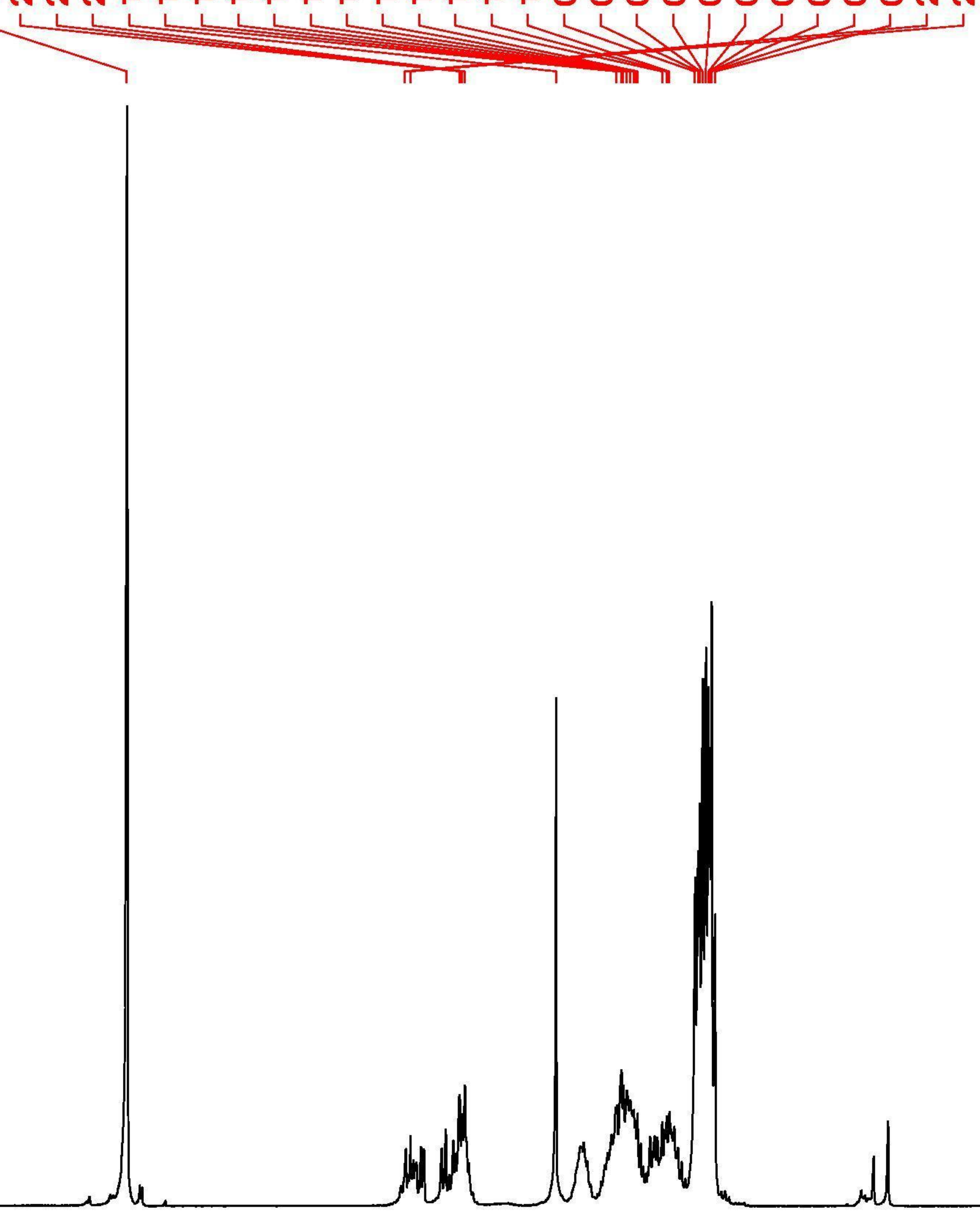


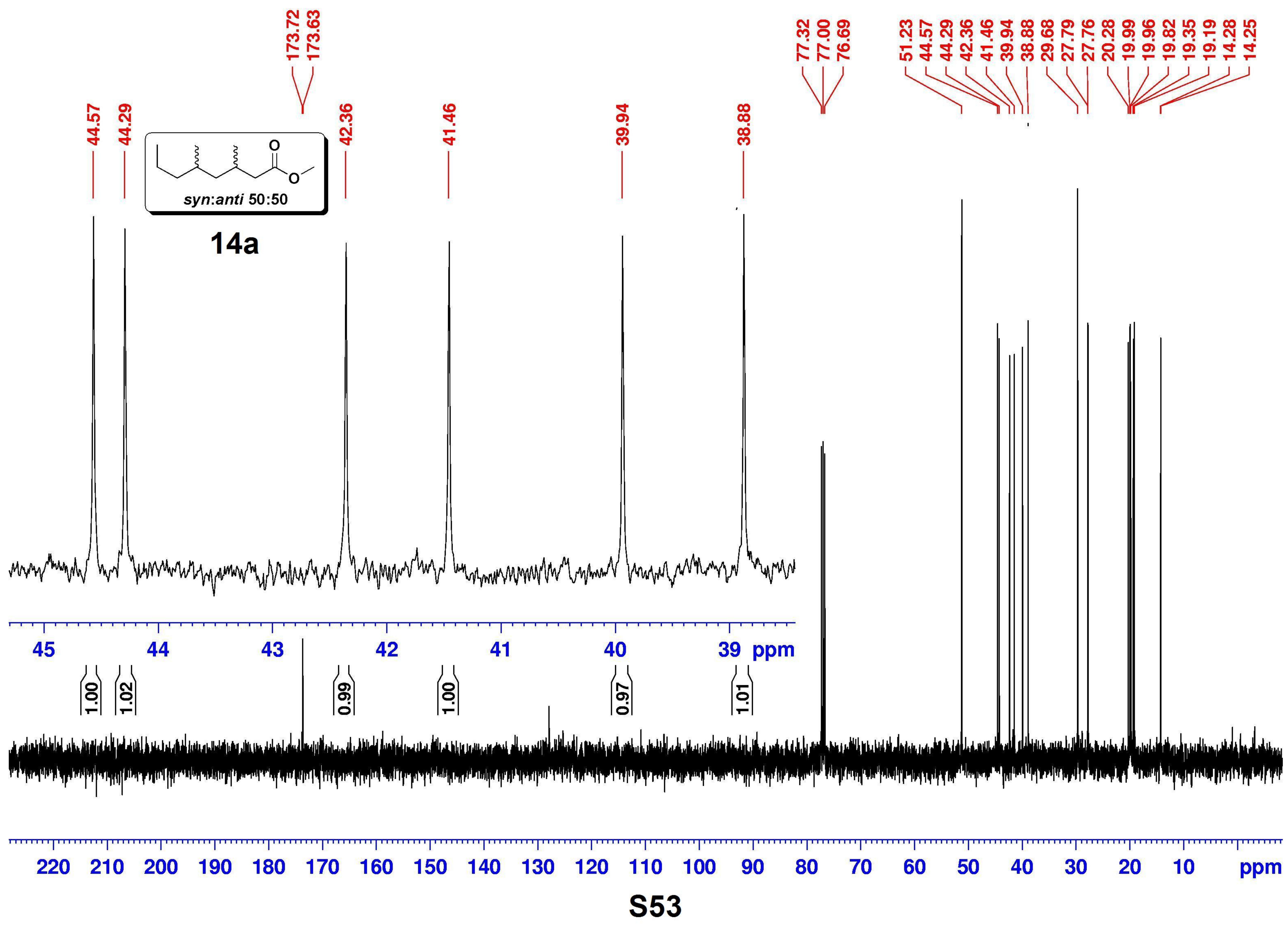




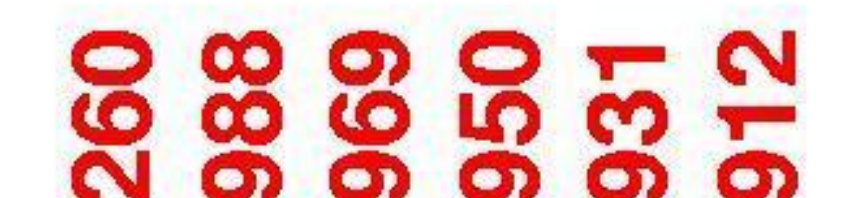

No

芦另

ถู

11

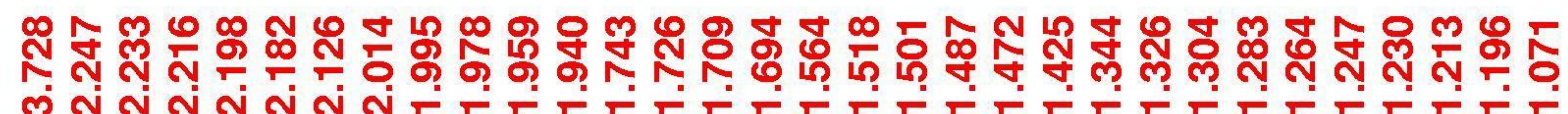

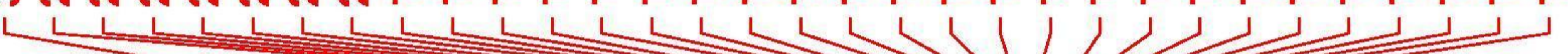

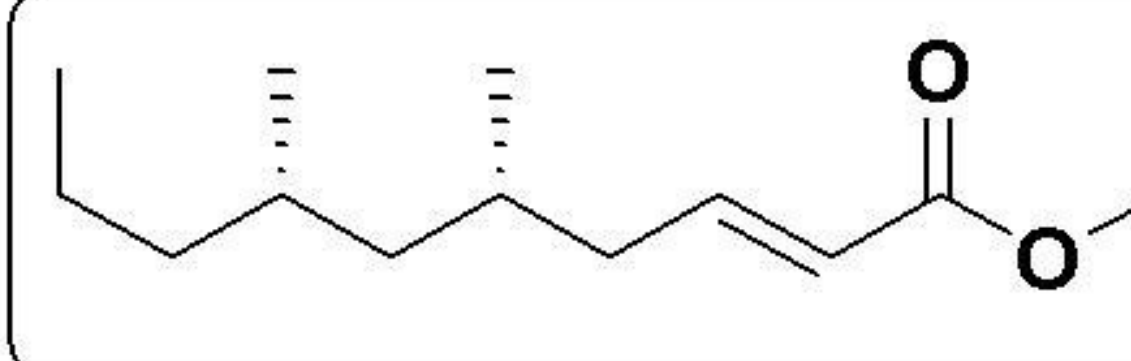

15

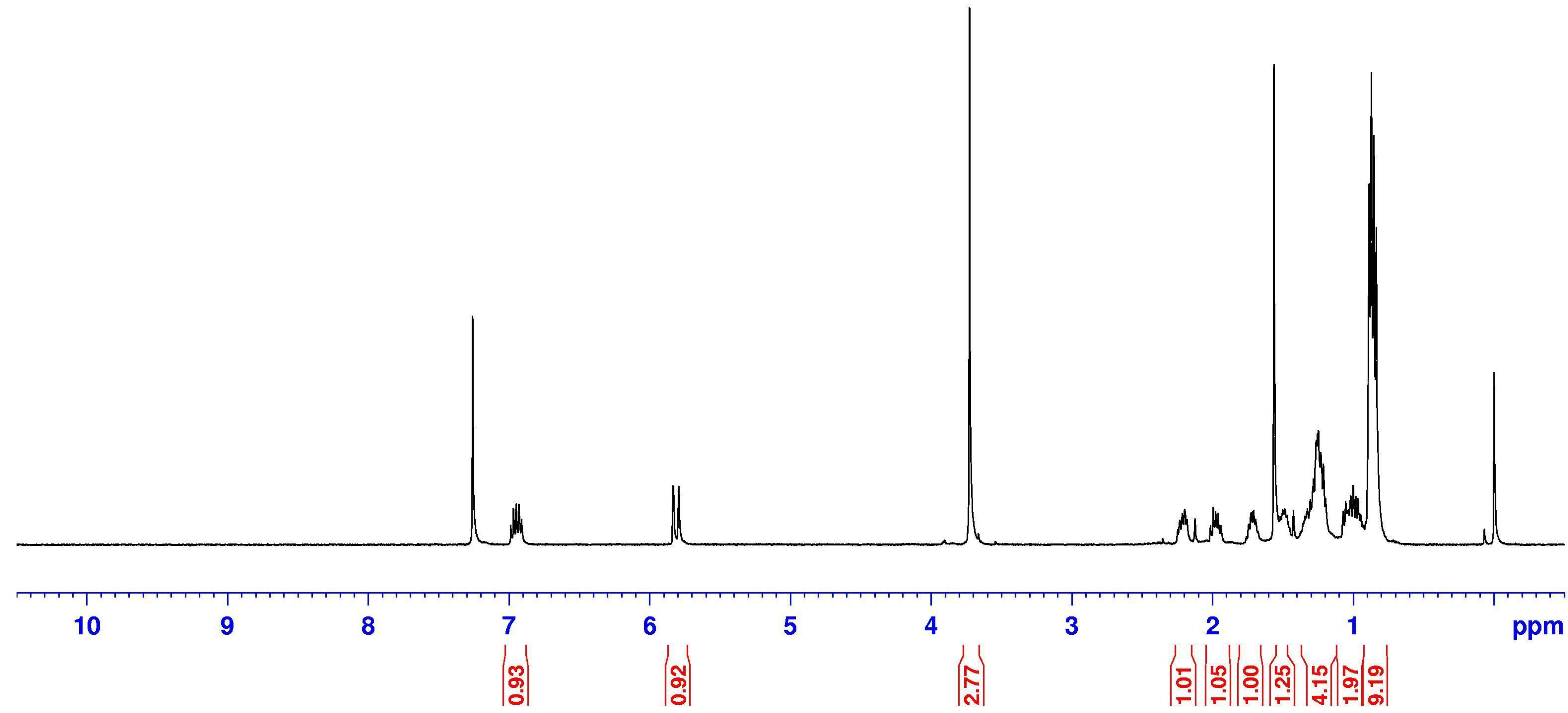

S54 


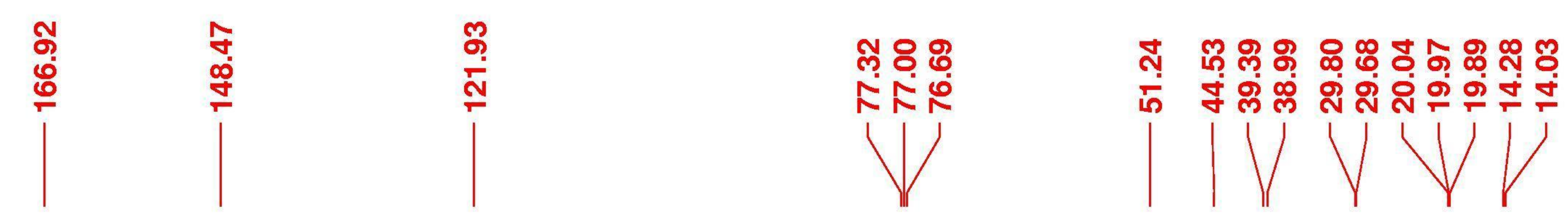

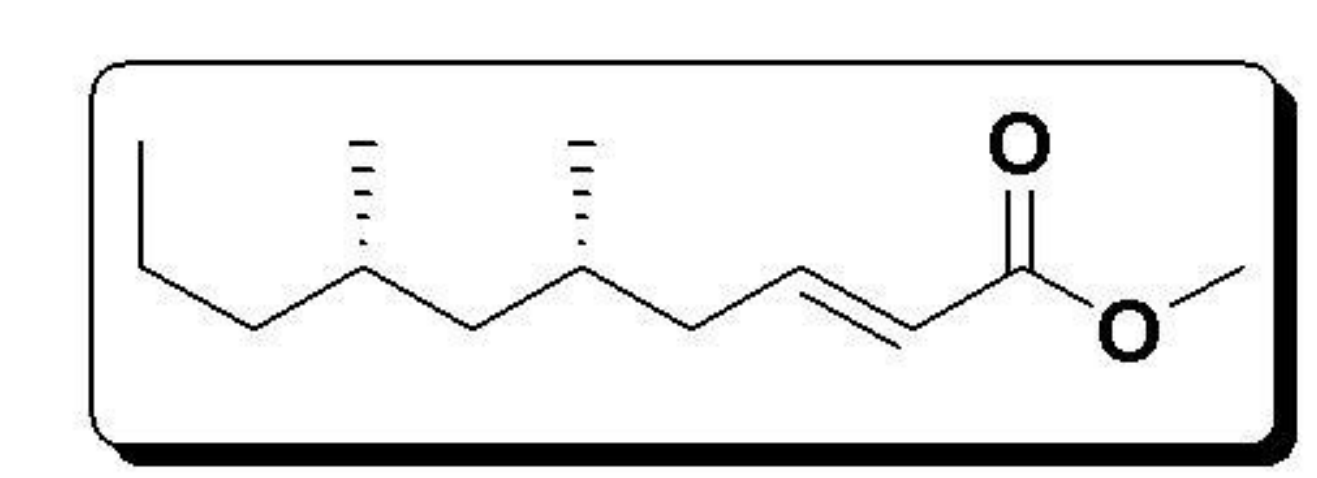

15

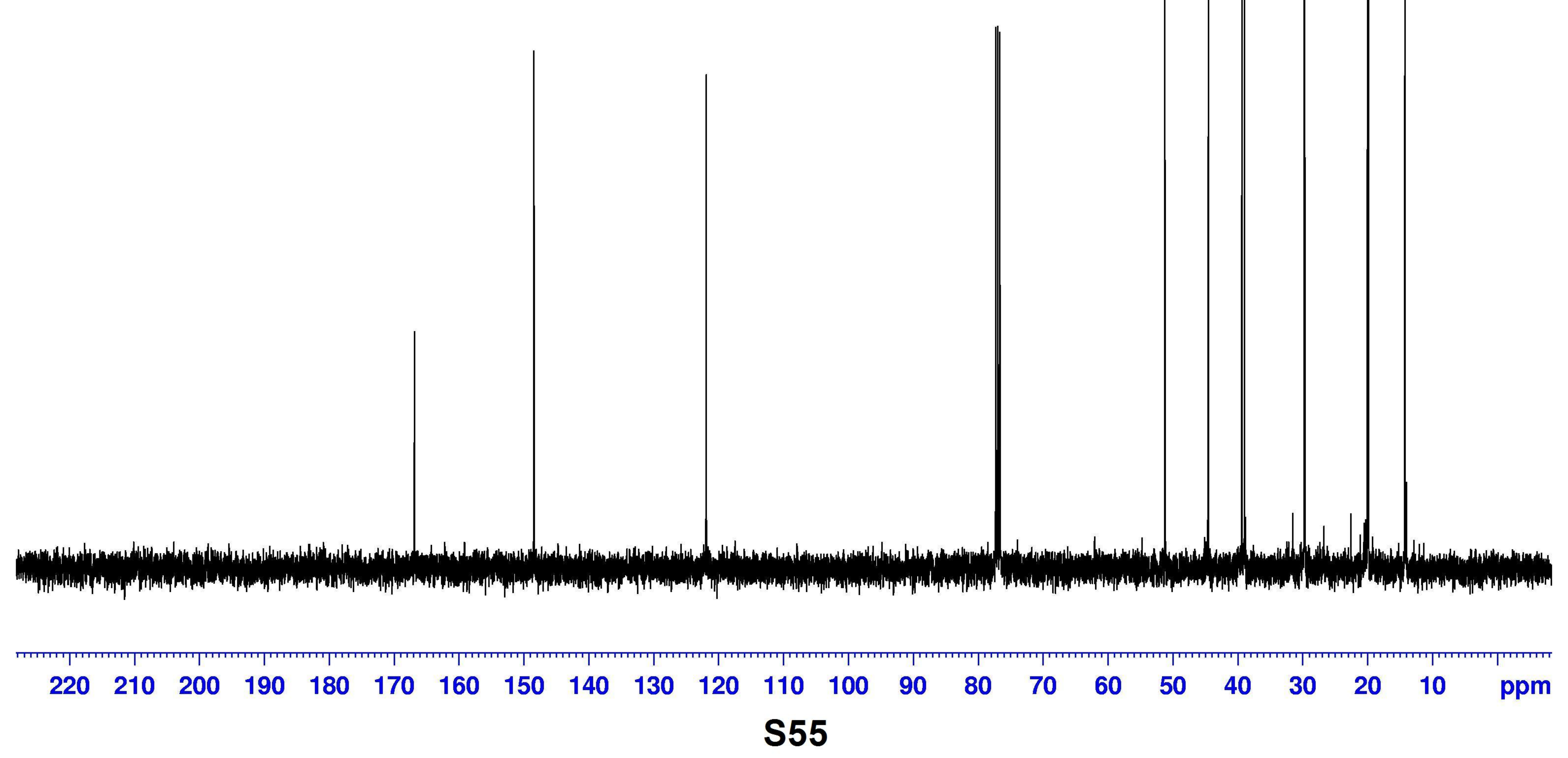




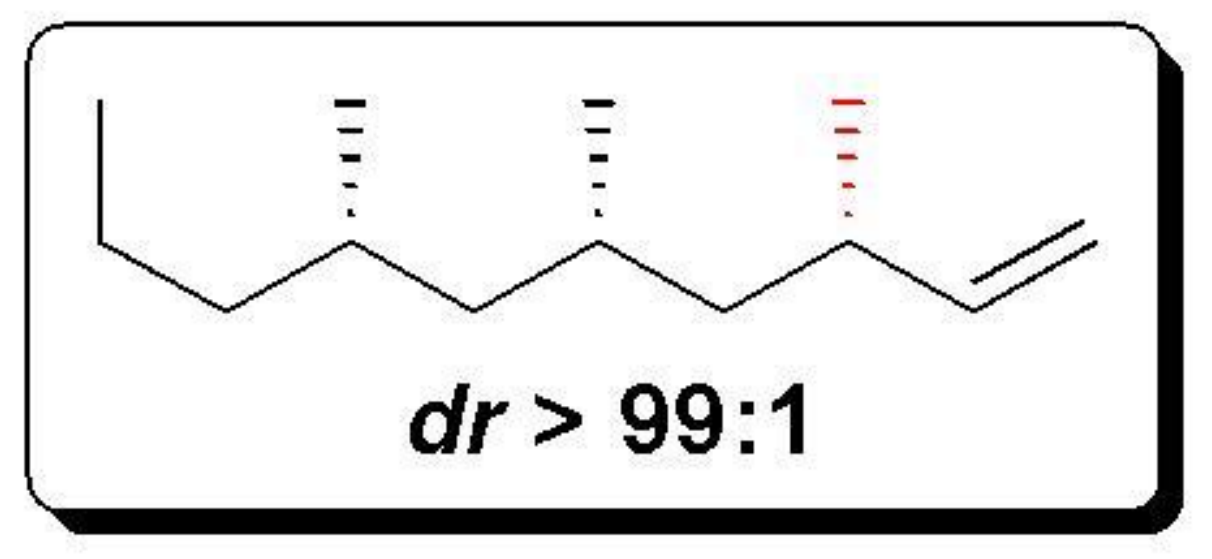

16

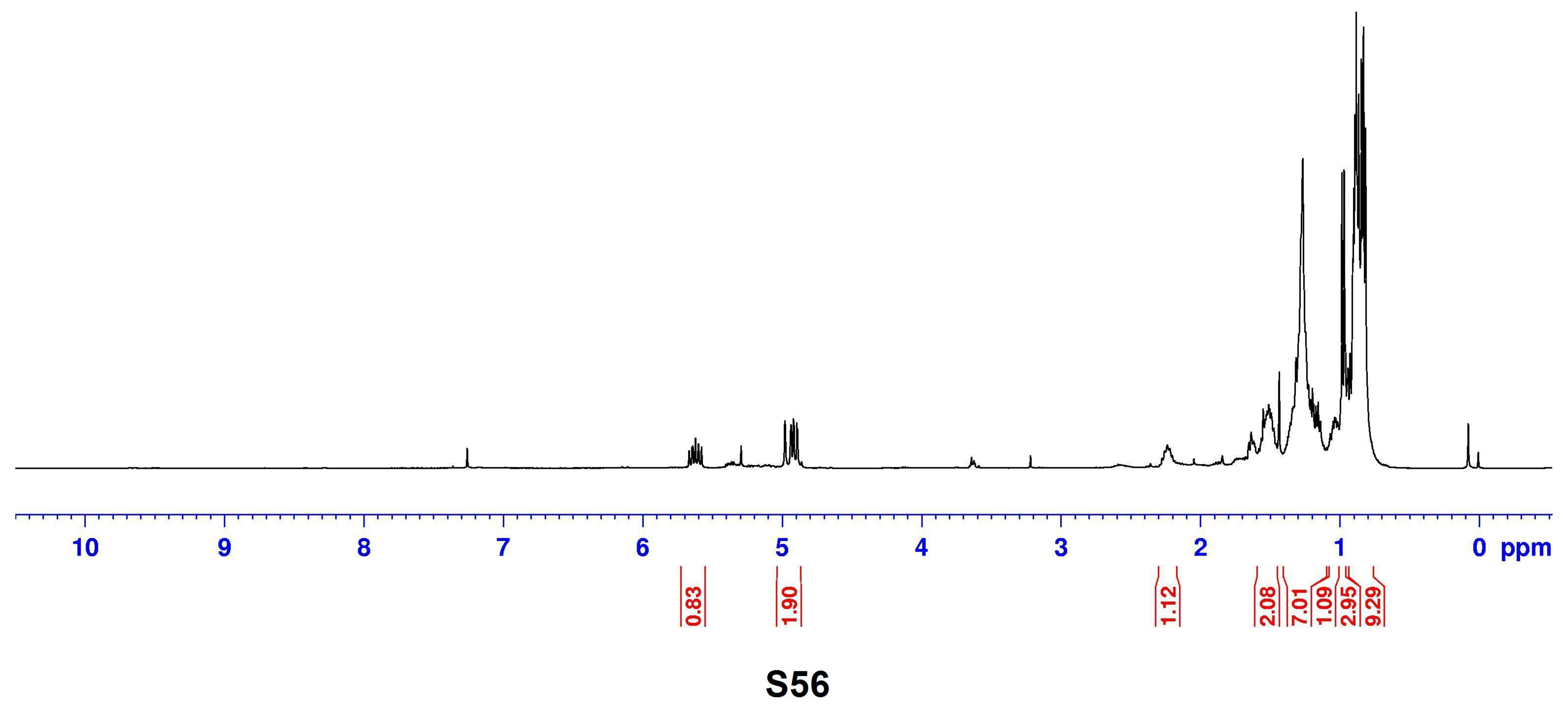



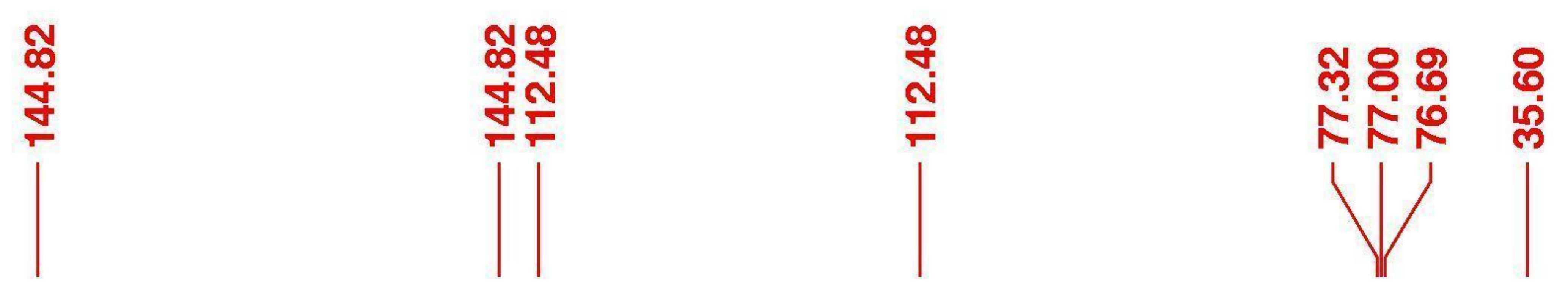

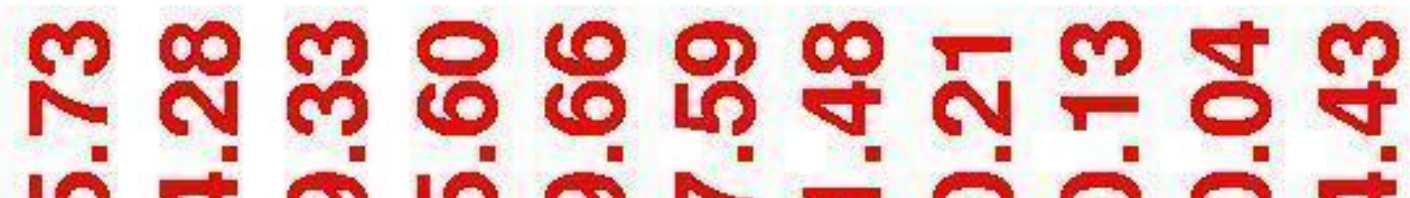

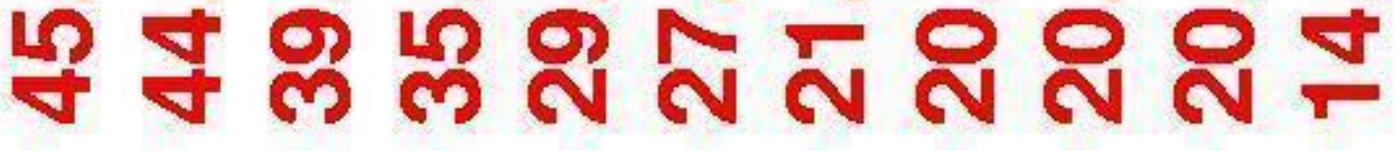
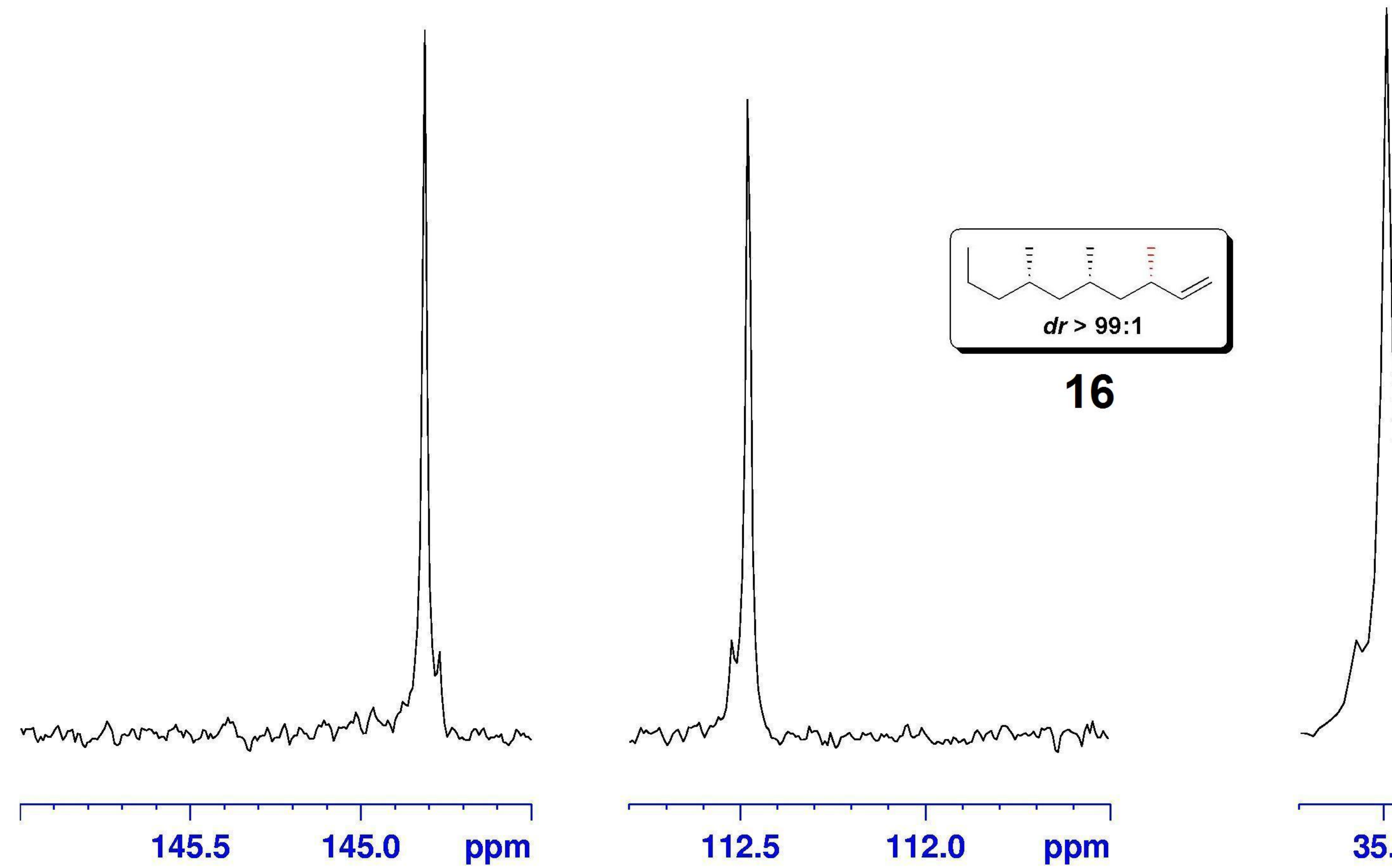

1111111

16

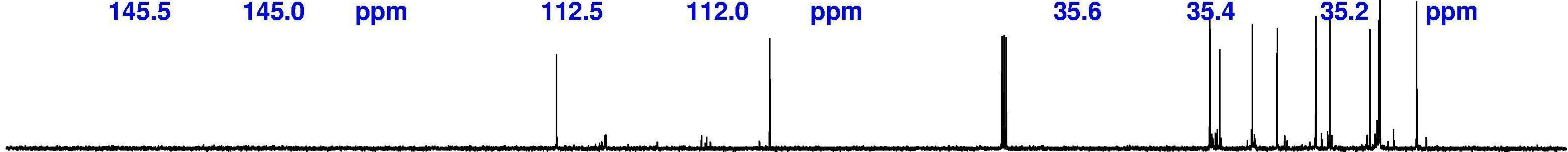




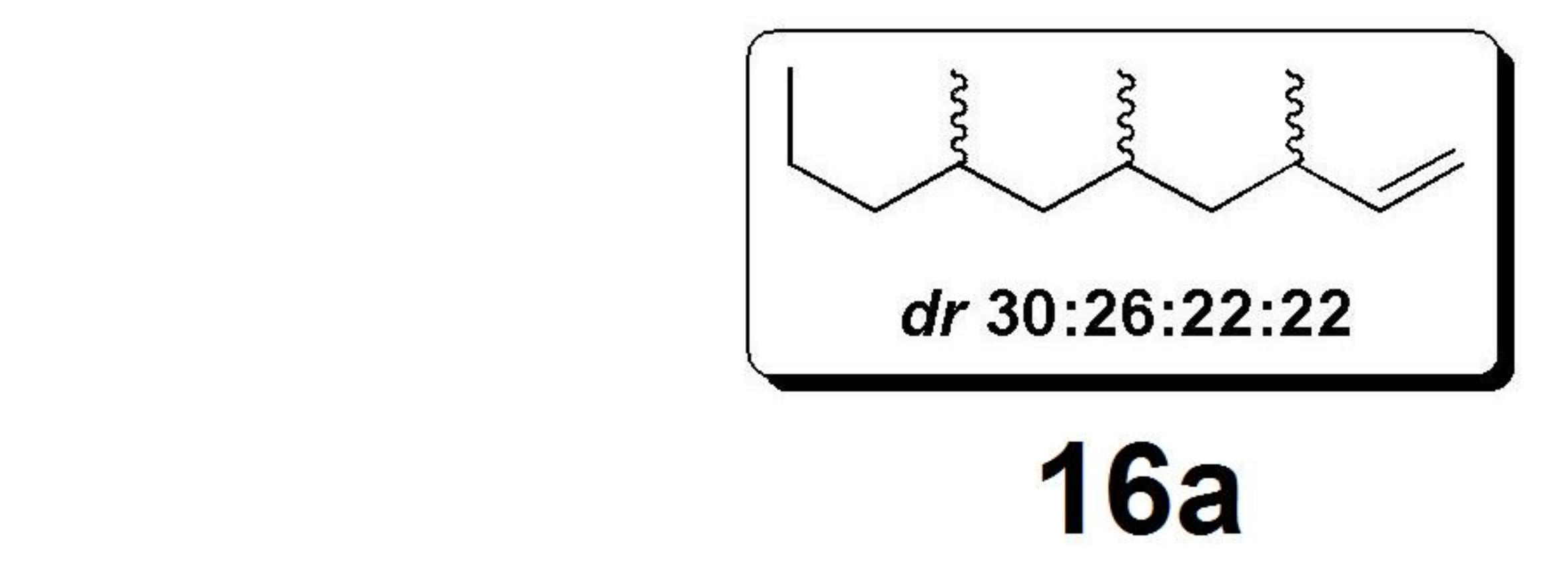

$16 \mathrm{a}$
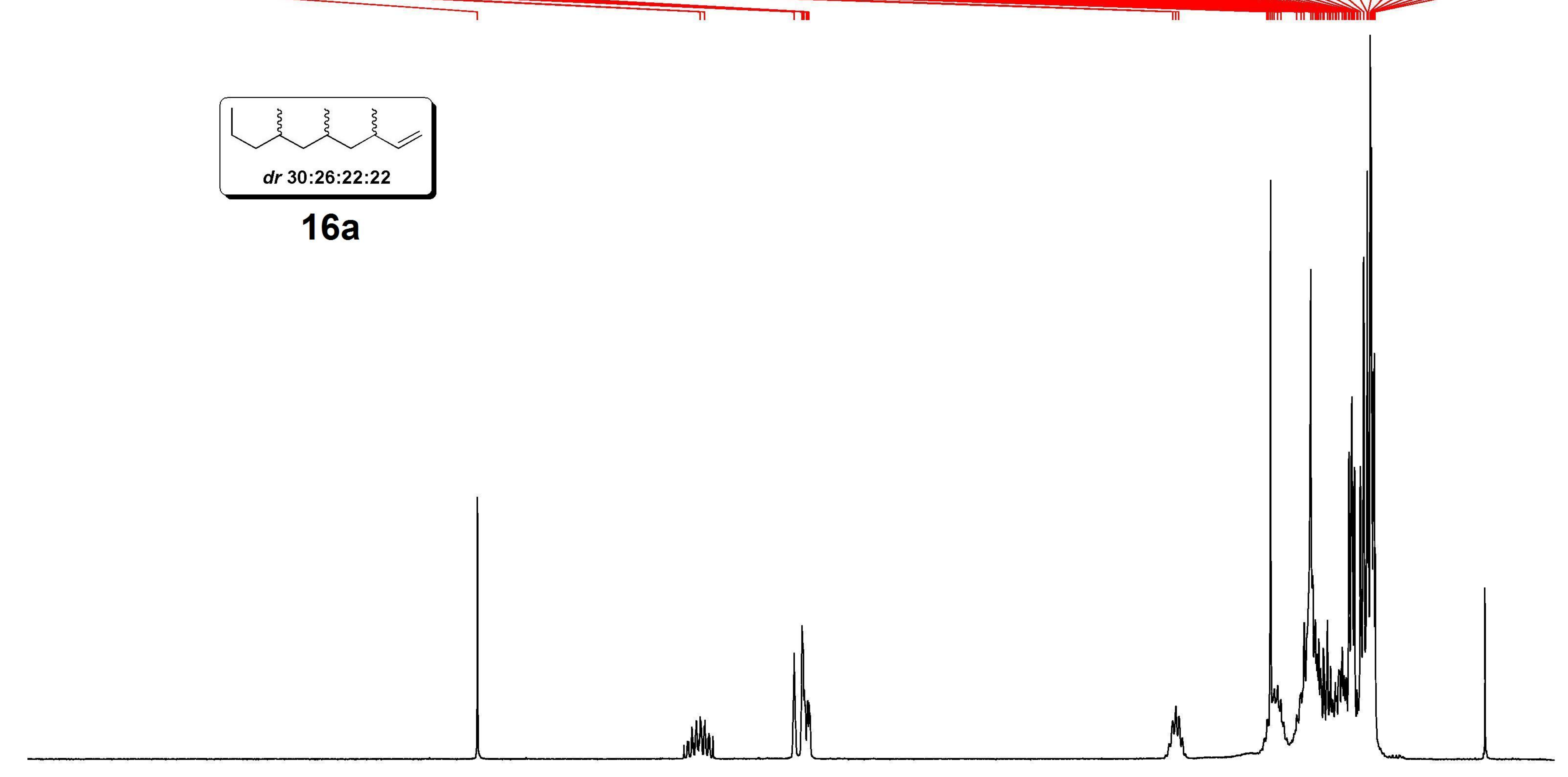

10

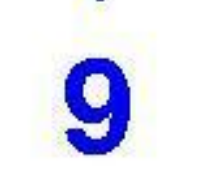

8

7

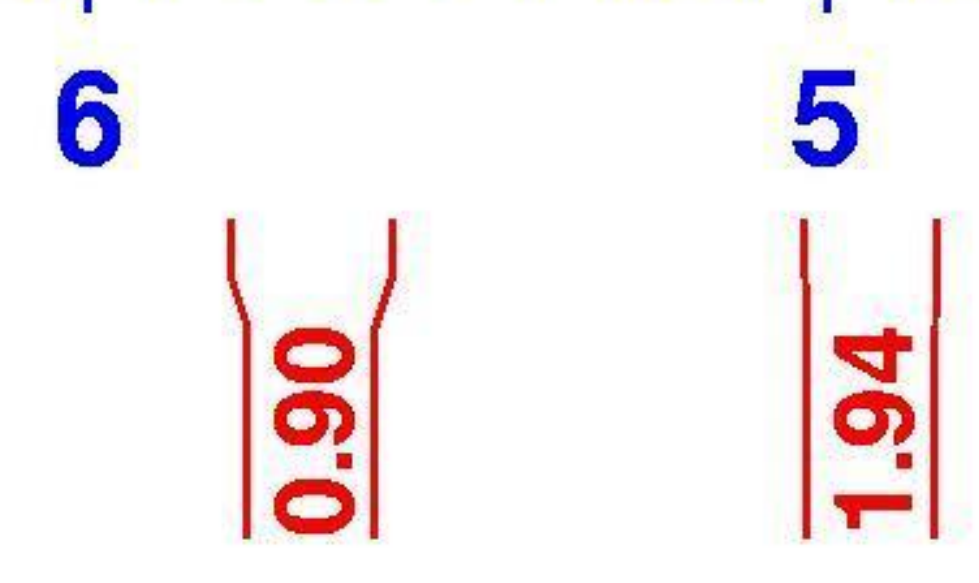

4

3

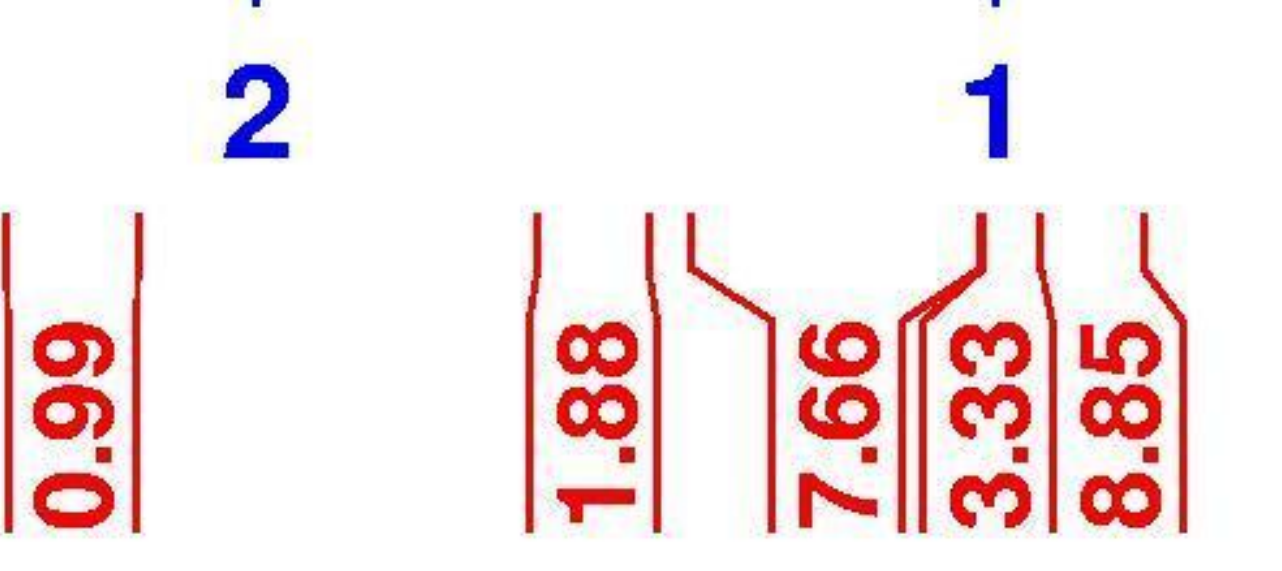

ppm

S58 


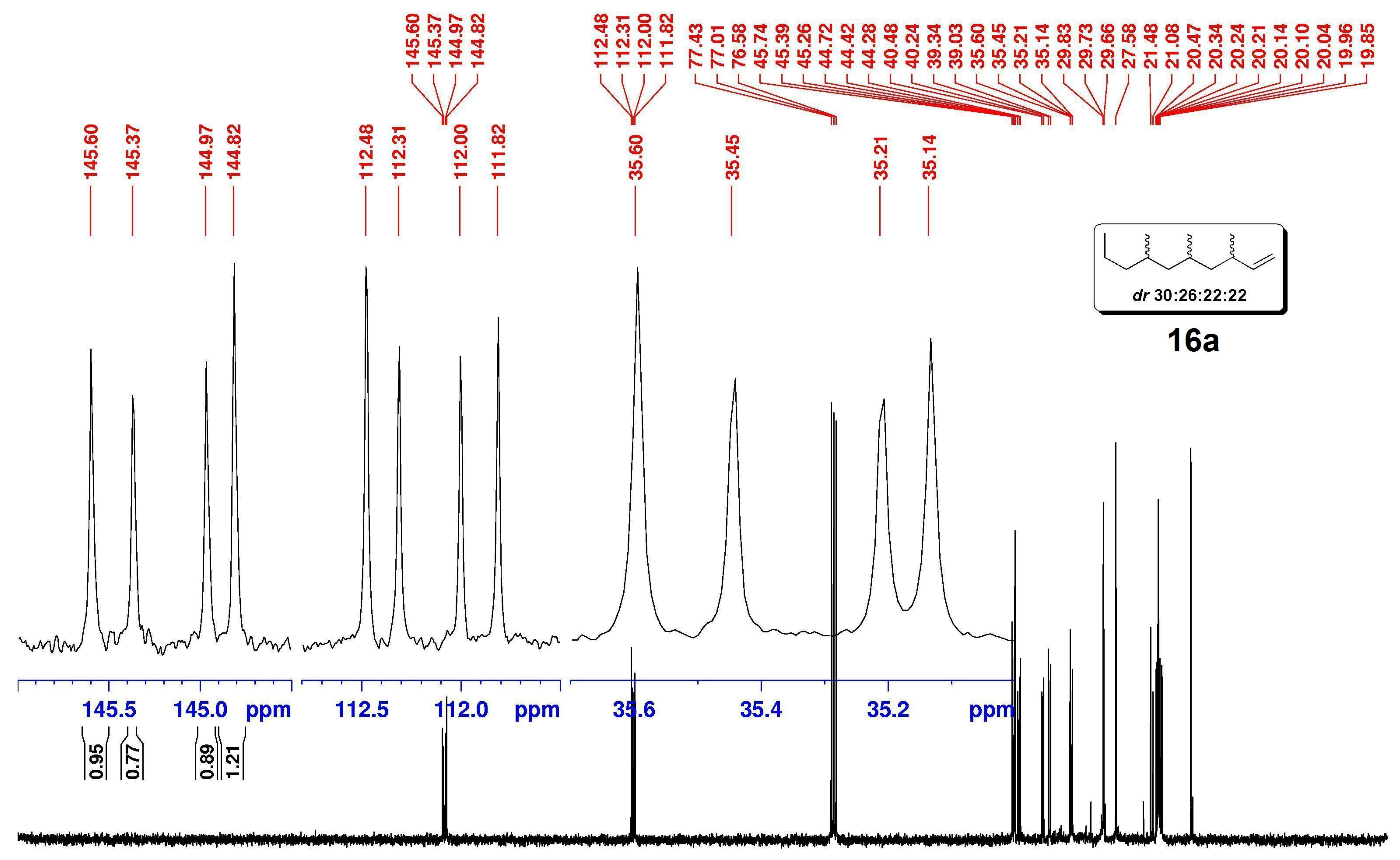

$\begin{array}{lllllllllllllllllllllll}210 & 200 & 190 & 180 & 170 & 160 & 150 & 140 & 130 & 120 & 110 & 100 & 90 & 80 & 70 & 60 & 50 & 40 & 30 & 20 & 10 & 0 & \text { ppm }\end{array}$ S59 


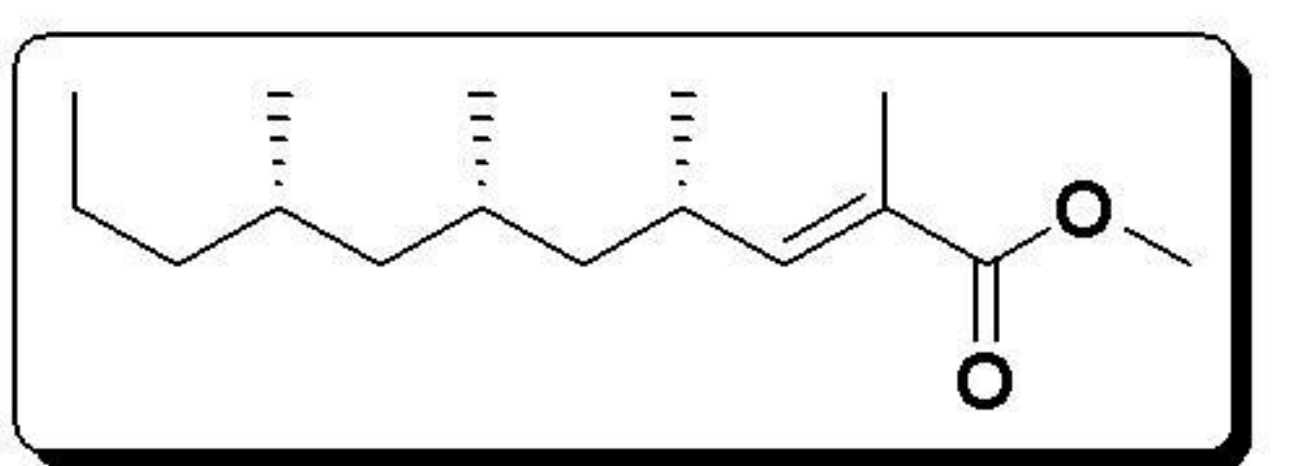

17

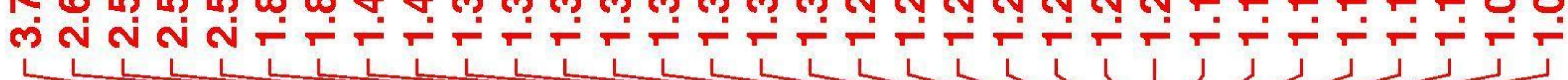

2
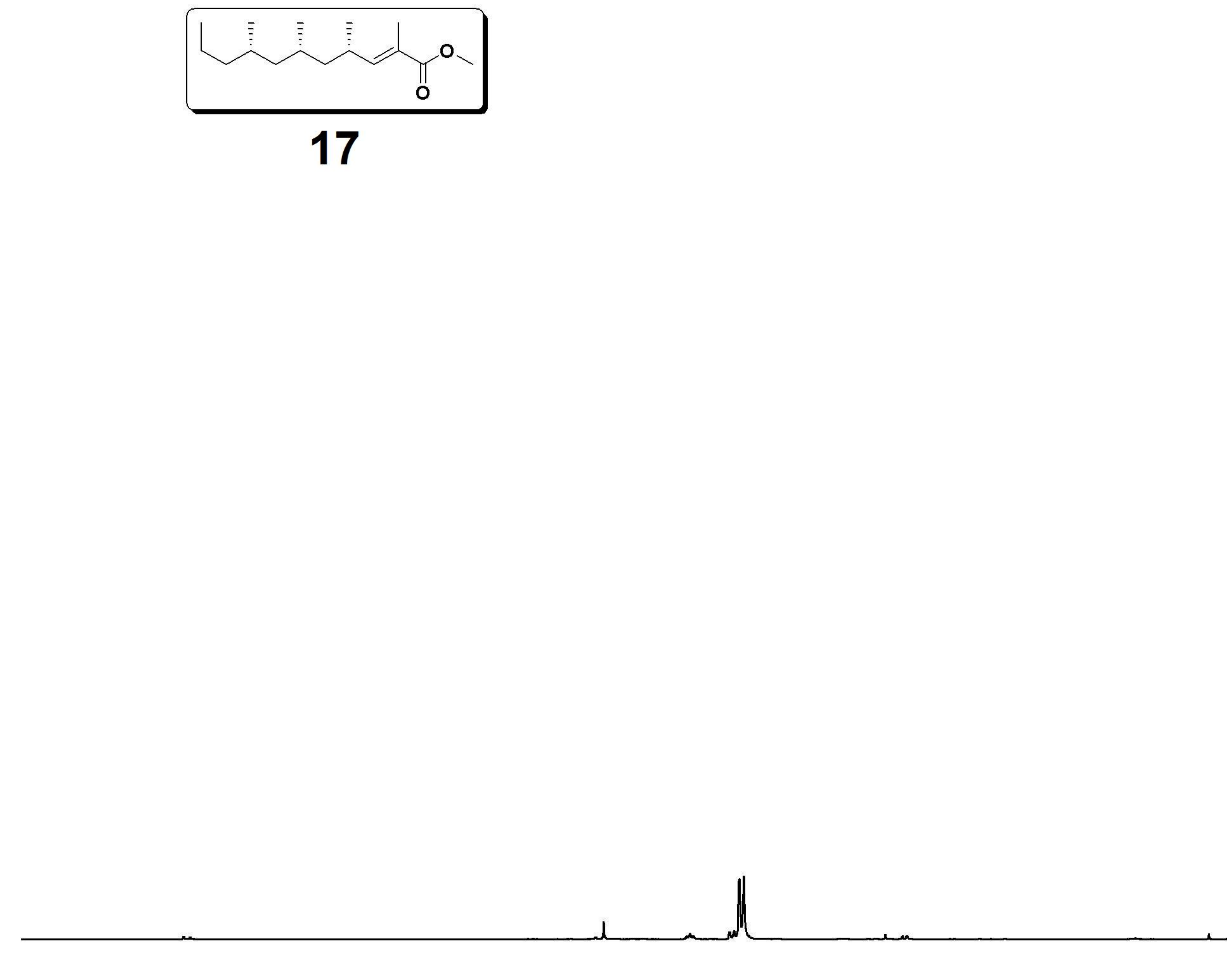

10

9

8

7

$\mid$

6

5

4

3

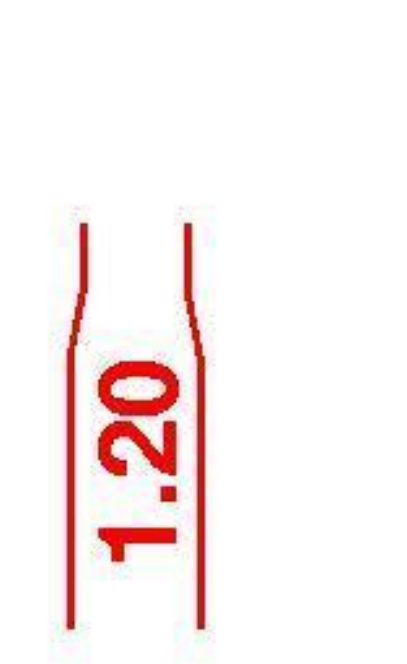

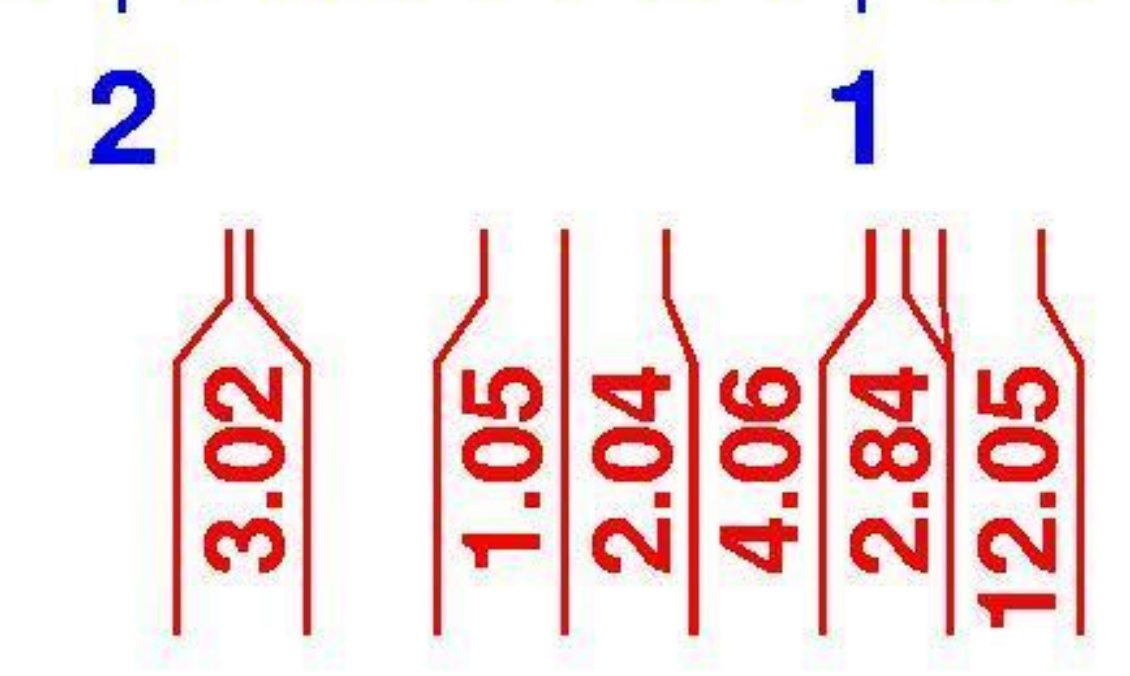

ppm

S60 


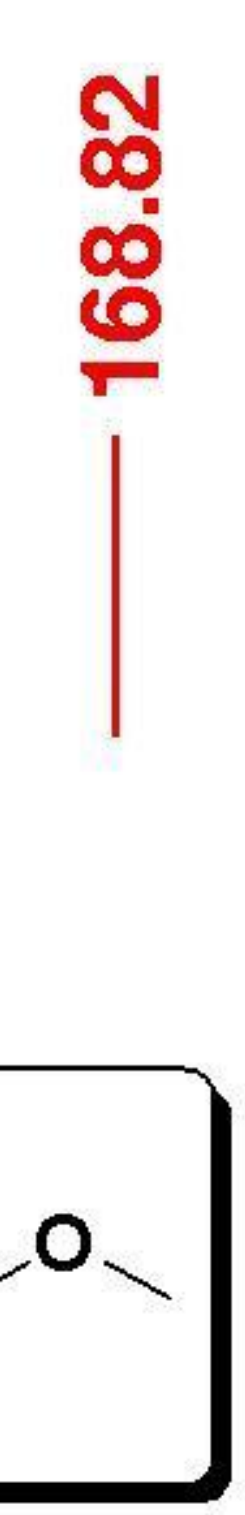

17

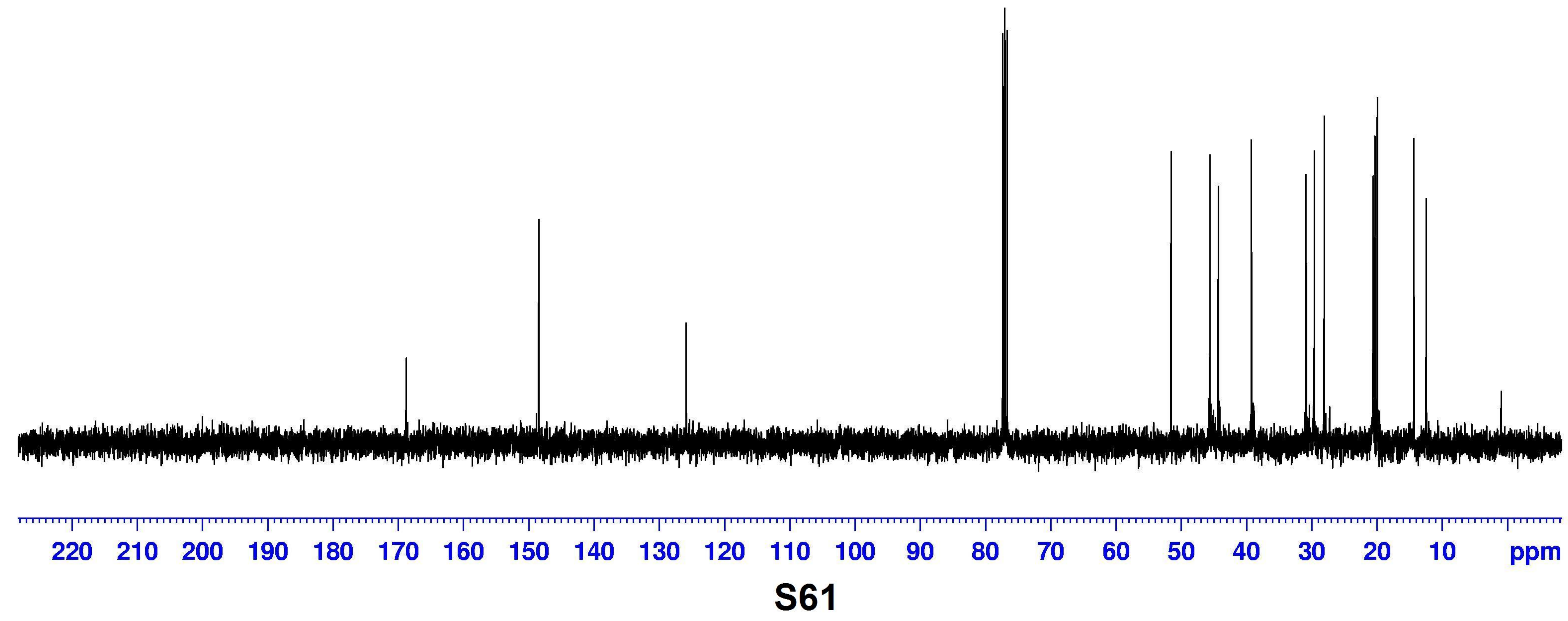




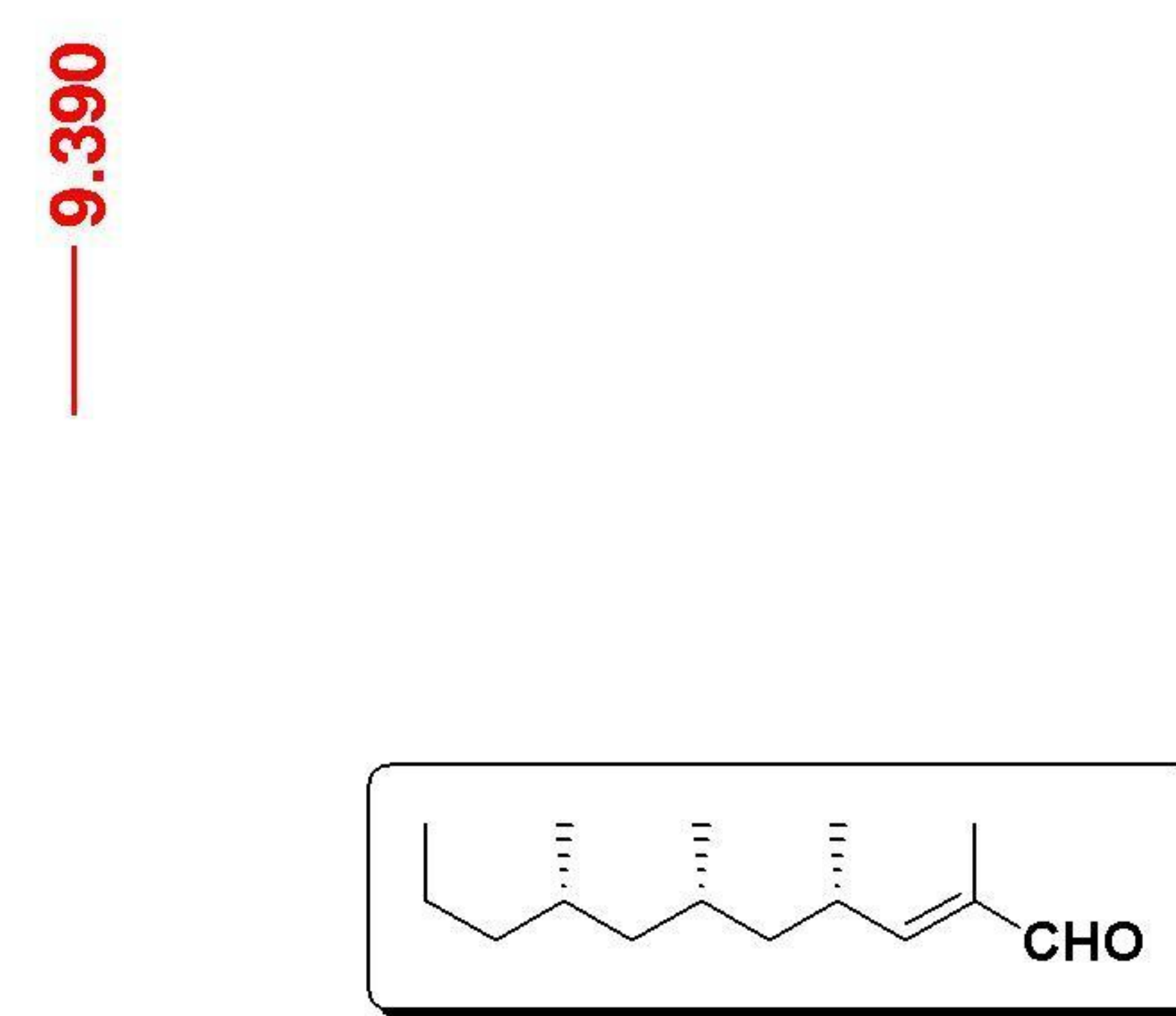

10

$\mathrm{CHO}$

\section{0}

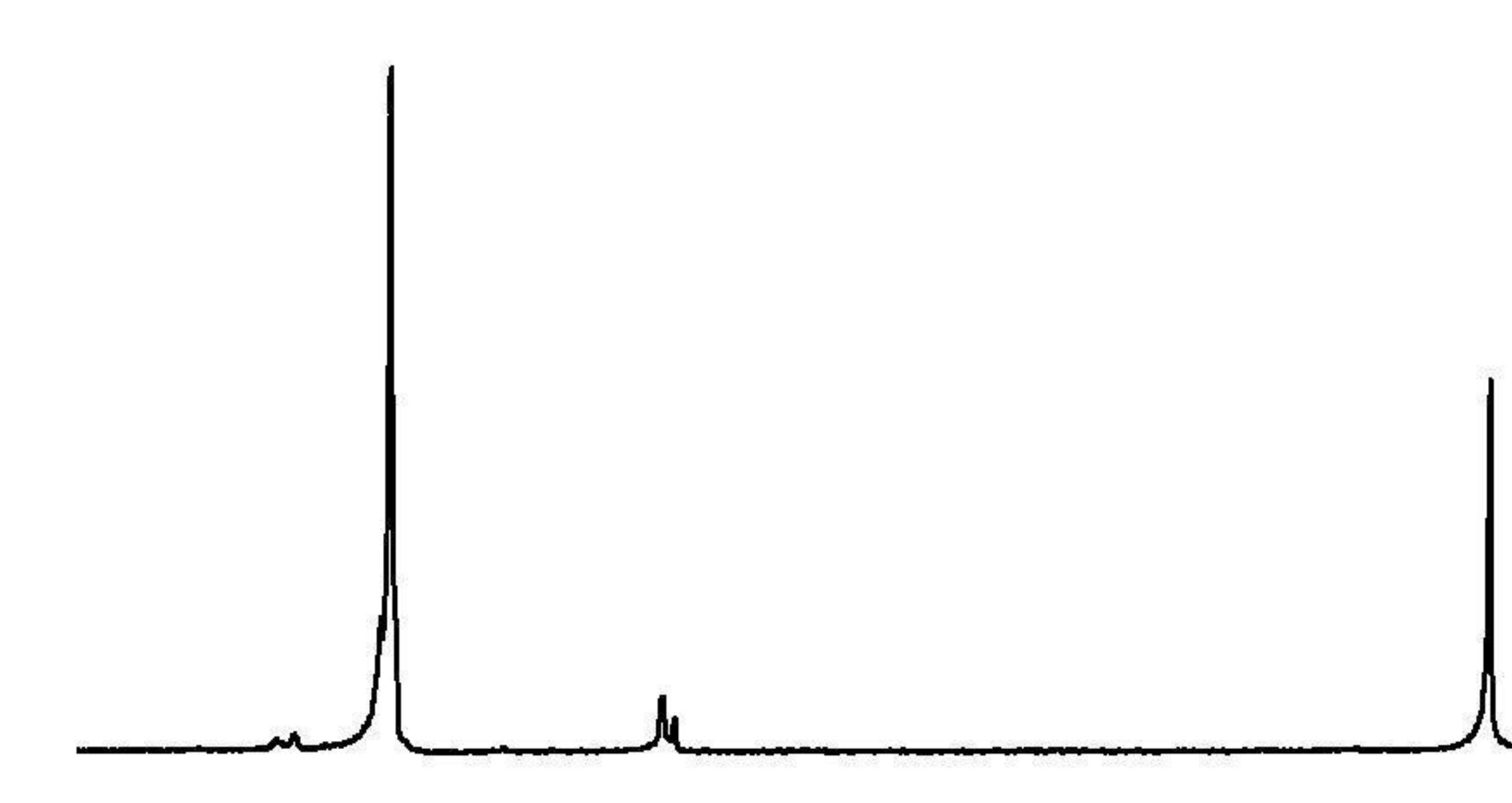

1
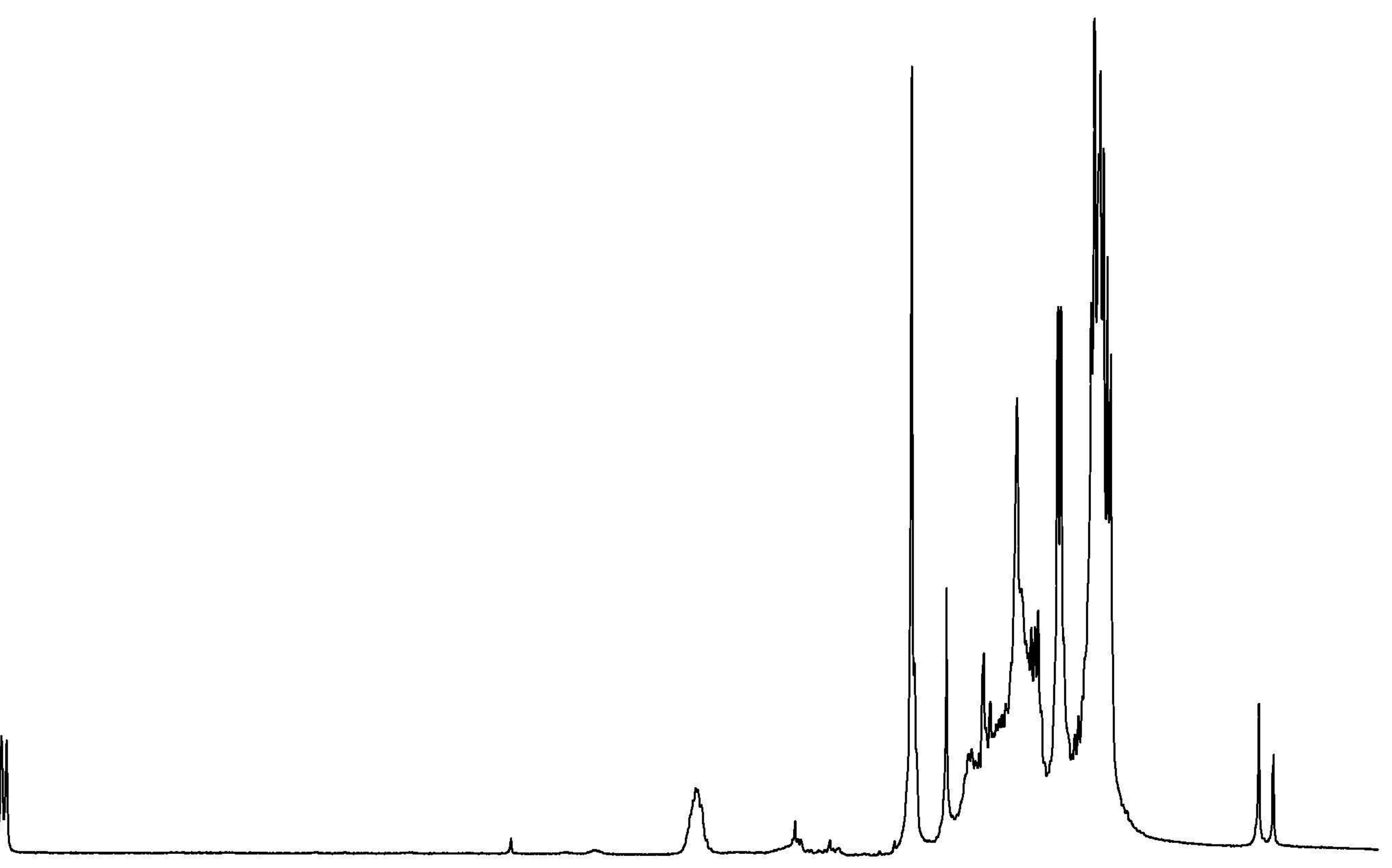

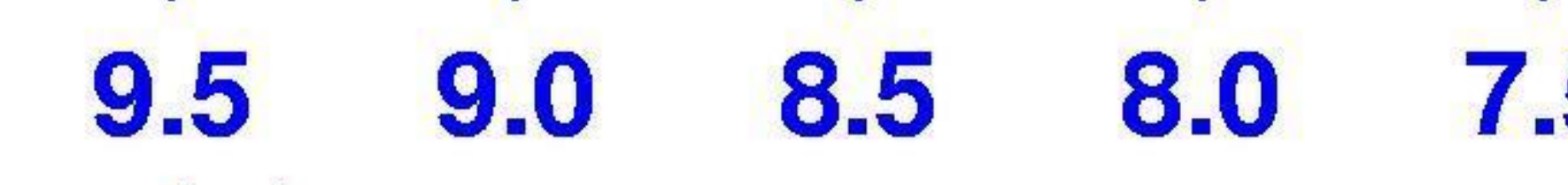

a

\begin{abstract}
6.5
$\begin{array}{ll}5.5 & 5.0\end{array}$
\end{abstract} $\mid$\begin{tabular}{l}
0 \\
\hdashline
\end{tabular}

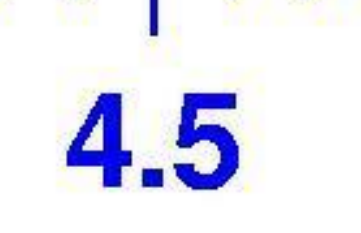

4.0

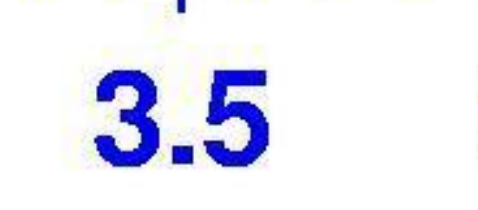

3.0
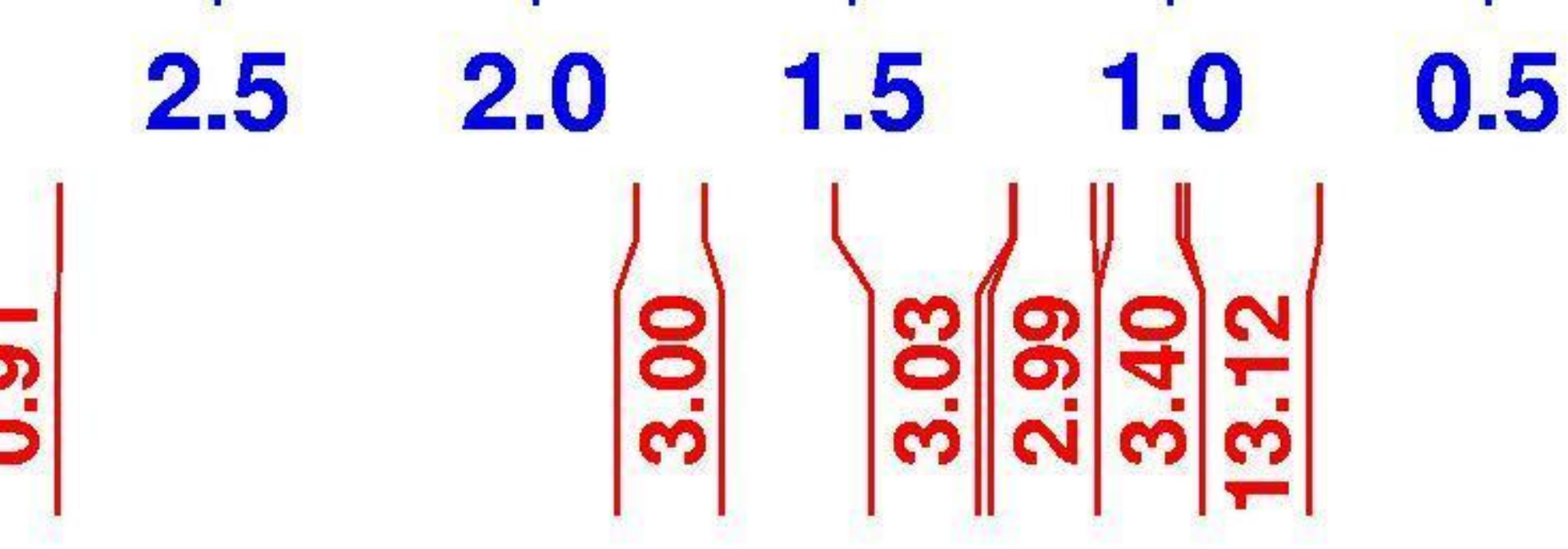

ppm

S62 


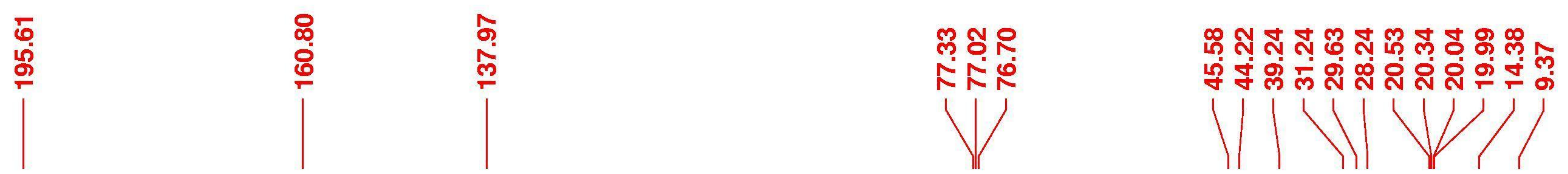

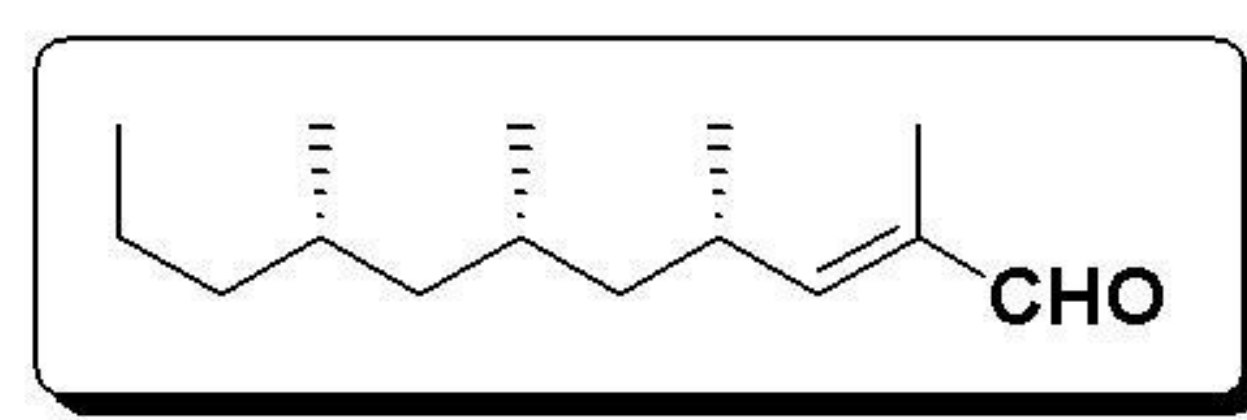

10
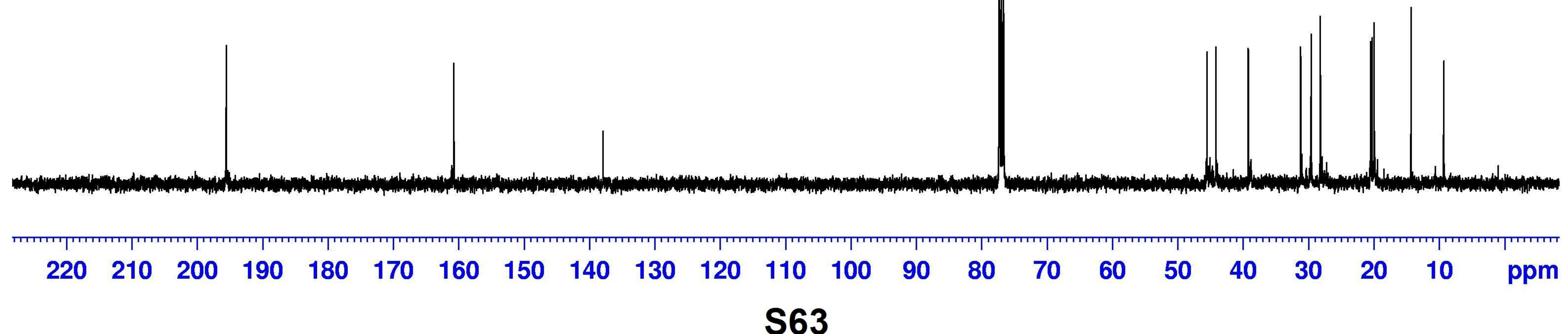


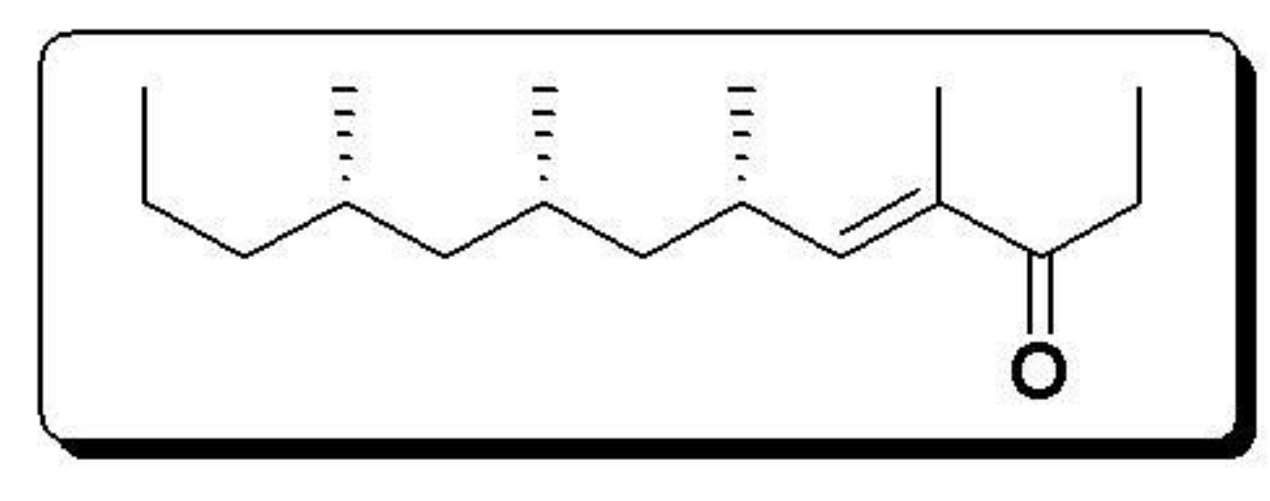

11

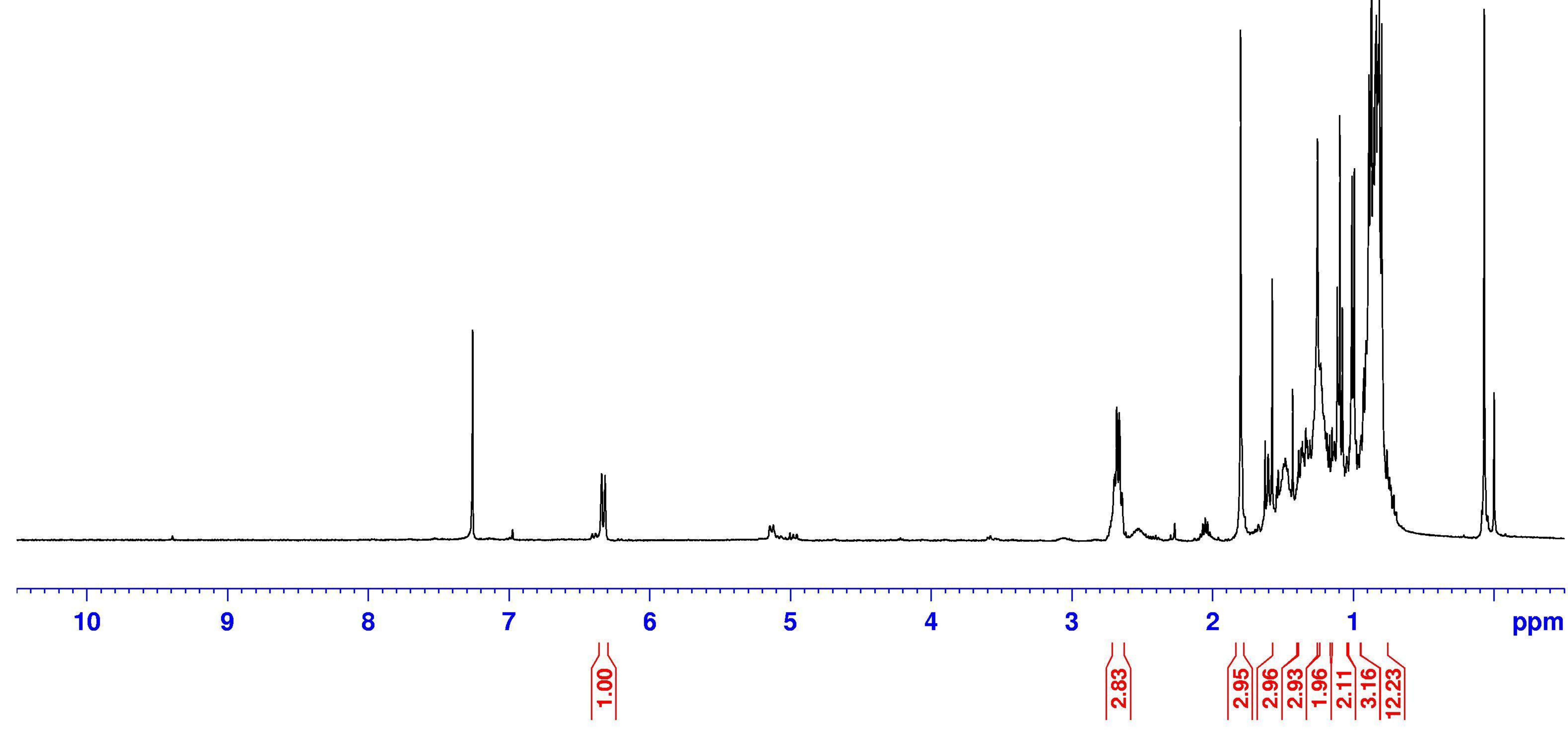

S64 

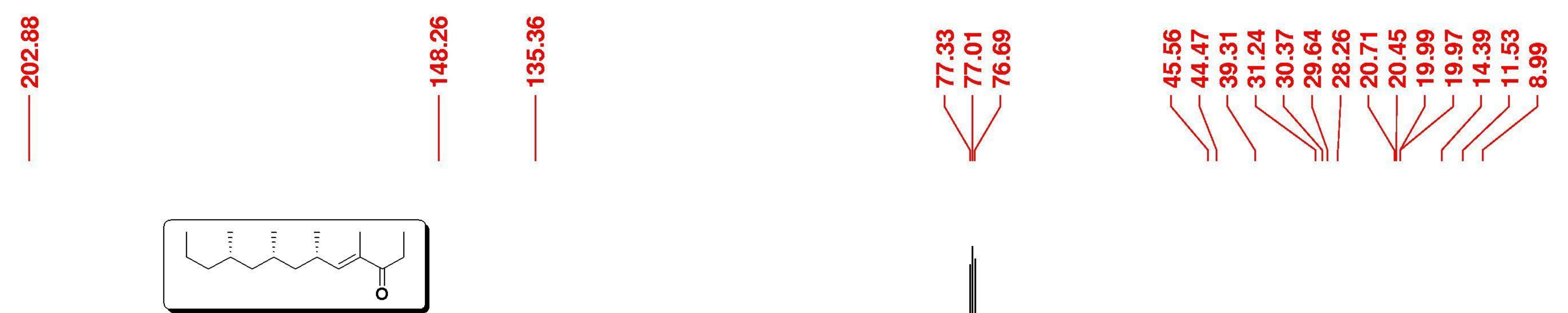

11

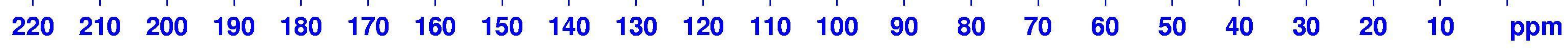
S65 